\title{
Late Triassic-earliest Jurassic geomagnetic polarity sequence and paleolatitudes from drill cores in the Newark rift basin, eastern North America
}

\author{
D. V. Kent, P. E. Olsen, and W. K. Witte ${ }^{1}$ \\ Lamont-Doherty Earth Observatory, Columbia University, Palisades, New York
}

\begin{abstract}
Paleomagnetic study of about 2400 samples from nearly $7 \mathrm{~km}$ of core recovered at seven drill sites in the Newark continental rift basin of eastern North America provides a detailed history of geomagnetic reversals and paleolatitudinal motion for about $30 \mathrm{~m}$.y. of the Late Triassic and earliest Jurassic (Carnian to Hettangian). Northward drift of only about $7^{\circ}$ is recorded in the continental sediments and minor interbedded basaltic lavas in the basin, from $2.5^{\circ}$ to $6.5^{\circ}$ north paleolatitude in the Carnian and from $6.5^{\circ}$ to $9.5^{\circ}$ north paleolatitude over the Norian-"Rhaetian" and the early Hettangian. A total of 59 polarity intervals, ranging from about $4 \mathrm{~m}$ to over $300 \mathrm{~m}$ in thickness, have been delineated in a composite stratigraphic section of $4660 \mathrm{~m}$. The lateral continuity and consistent relationship of lithological lake level cycles and magnetozones in the stratigraphically overlapping sections of the drill cores demonstrate their validity as time markers. A geomagnetic polarity timescale was constructed by scaling the composite section assuming that lithostratigraphic members in the predominant lacustrine facies represent the 413-kyr orbital periodicity of Milankovitch climate change and by extrapolating a sedimentation rate for the fluvial facies in the lower part of the section; a $202 \mathrm{Ma}$ age for the palynological Triassic/Jurassic boundary was used to anchor the chronology based on published concordant radiometric dates linked to the earliest Jurassic igneous extrusive zone. Geomagnetic polarity intervals range from about 0.03 to $2 \mathrm{~m} . y$. , have a mean duration of about $0.5 \mathrm{~m} . \mathrm{y}$., and show no significant polarity bias. The cyclostratigraphically calibrated record provides a reference section for the history of Late Triassic-earliest Jurassic geomagnetic reversals. Correlations are attempted with available magnetostratigraphies from nonmarine sediments from the Chinle Group of the southwestern United States and marine limestones from Turkey.
\end{abstract}

\section{Introduction}

The global nature of geomagnetic polarity reversals has made magnetostratigraphy an essential tool for precise correlation between widely distributed sections of rocks of different lithological and biotic facies. The best documented history of geomagnetic polarity reversals is for the Jurassic to Recent and is based on the analysis of marine magnetic anomaly profiles from the global ocean [e.g., Cande and Kent, 1992; Gradstein et al., 1994]. The relative spacing of polarity intervals is established from the anomaly patterns and is calibrated in time by correlation to magnetostratigraphic sections with biostratigraphy, radiometric dates, and now by cyclostratigraphy [e.g., Shackleton et al., 1990; Hilgen, 1991]. Because of the absence of seafloor and hence marine magnetic anomalies, a geomagnetic polarity reference scale for pre-Jurassic time is much less well developed and requires long, continuous magnetostratigraphic sections with good chronostratigraphic control from the continents.

A very thick sequence of lacustrine and fluvial sediments is represented in the Newark Basin, one of the largest of a chain

${ }^{1}$ Now at Geophysical Institute, University of Alaska, Fairbanks.

Copyright 1995 by the American Geophysical Union.

Paper number 95JB01054.

0148-0227/95/95JB-01054\$05.00 of Mesozoic rift basins that developed along the margin of eastern North America in the early stages of formation of the Atlantic Ocean [Manspeizer, 1988]. Deposition in the basin is now known to span much of the the Late Triassic to earliest Jurassic [Cornet and Olsen, 1985] and was punctuated only by a brief igneous intrusive and extrusive episode just after the Triassic/Jurassic boundary [Olsen and Sues, 1986; Fowell et al., 1994] and dated at 201-202 Ma [Sutter, 1988; Dunning and Hodych, 1990]. The lacustrine sediments that constitute much of the Newark Basin section record climatically induced lake level variations reflecting Milankovitch orbital forcing [Van Houten, 1964; Olsen, 1986]. These climatic cycles constitute a basis for detailed lithostratigraphic correlation as well as chronological scaling.

Early paleomagnetic work on Newark Supergroup rocks focused on the igneous units and found mostly normal polarity magnetizations [e.g., DuBois et al., 1957; Opdyke, 1961; Smith and Noltmier, 1979]. This contributed to the concept of a quiet or long normal polarity interval in the Late Triassic and Early Jurassic [McElhinny and Burek, 1971; Perchesky and Khramov, 1973; Irving and Pullaiah, 1976; Haq et al., 1988]. More extensive sampling of the Newark Basin sedimentary section has revealed the presence of numerous polarity reversals [McIntosh et al., 1985; Witte and Kent, 1989, 1990; Witte et al., 1991]. The Newark Basin section thus provides an opportunity to obtain a cyclostratigraphically scaled, high-resolution timescale of 


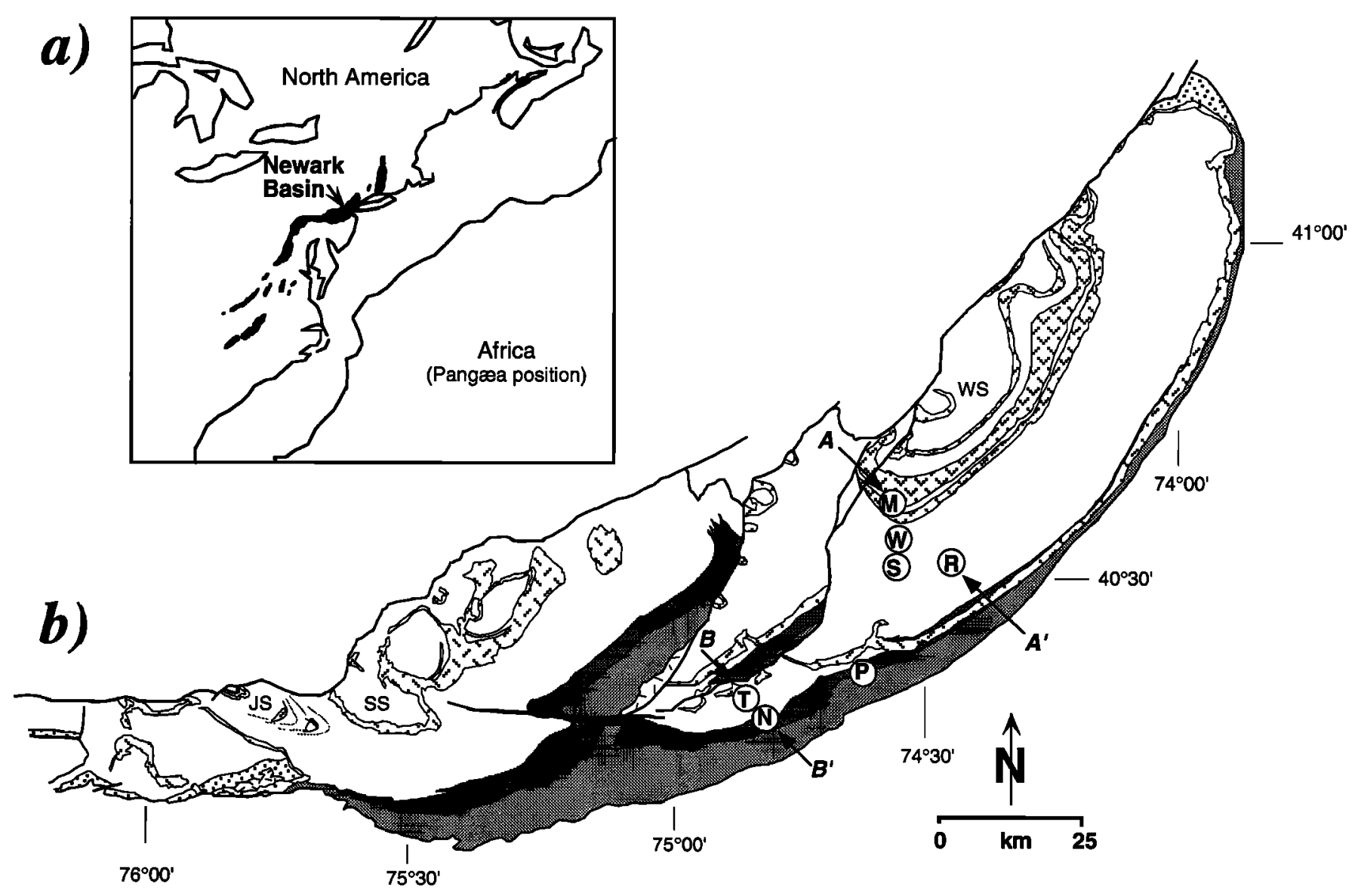

c)

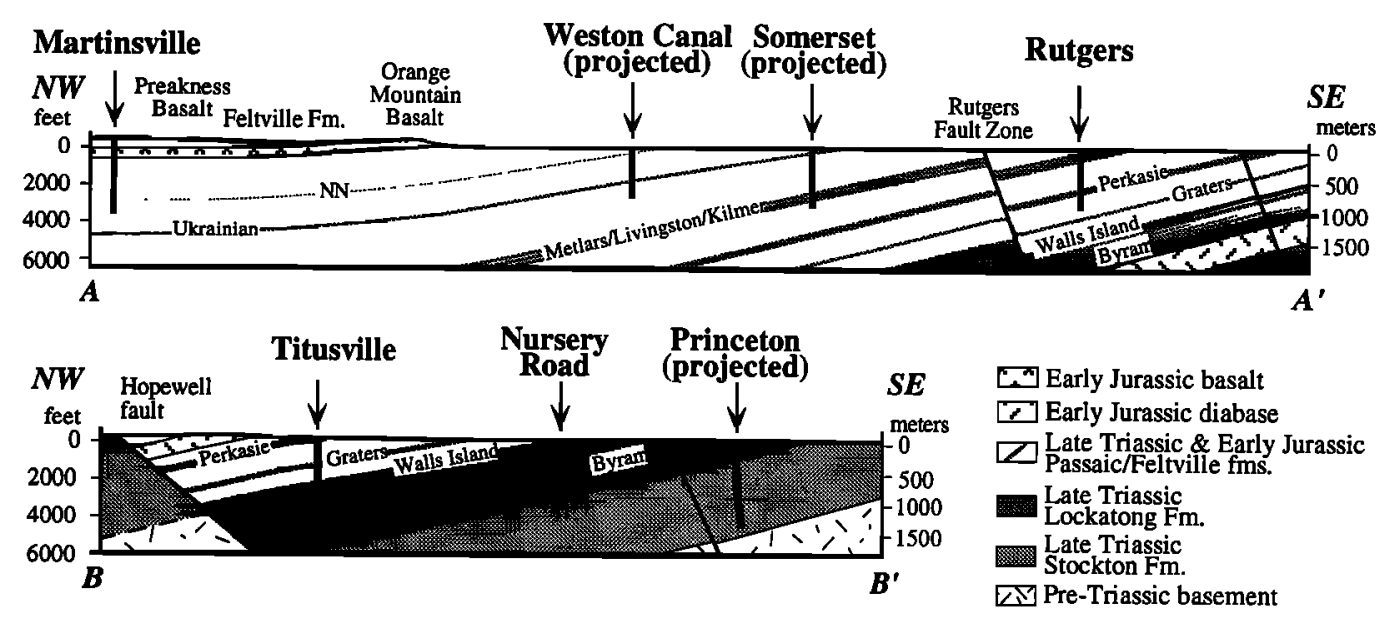

Figure 1. (a) Location of the Newark Basin among other early Mesozoic rift basins (dark shading) in eastern North America which is shown in a predrift (Pangea) continental configuration with respect to Africa. (b) Geological sketch map of the Newark Basin with the location of Newark Basin Coring Project drill sites indicated by the circled first letter of the site name. Other localities referred to in the text are WS, Watchung syncline; SS, Sassamansville syncline; JS, Jacksonwald syncline. (c) Cross sections showing positions of NBCP drill sites projected onto A-A' and B-B' of Figure $1 \mathrm{~b}$.

Late Triassic and earliest Jurassic geomagnetic polarity reversals. Outcrop exposure is, however, typically poor and discontinuous due to the low relief and urbanized setting of the basin. This difficulty was addressed by the National Science Foundation-sponsored Newark Basin Coring Project (NBCP) which resulted in the recovery of a virtually complete stratigraphic section through the thick continental rift basin sequence of central New Jersey from seven stratigraphically overlapping drill cores. The lithostratigraphy and cyclostratigraphy of the NBCP cores are described by Olsen et al. [1995] and Olsen and Kent [1995]. The paleomagnetism of the NBCP cores is reported here. 


\section{Geologic Setting and Coring}

An extensive series of rift basins formed in eastern North America during the initial rifting of Pangea (Figure 1a). These rifts filled with thousands of meters of continental sediments, basalts, and diabase termed the Newark Supergroup [Olsen, 1978, 1980; Froelich and Olsen, 1984]. The Newark Basin, about $190 \mathrm{~km}$ long and up to $50 \mathrm{~km}$ wide, is the largest of the exposed Newark Supergroup basins. It is a half graben bound on the northwest by a set of predominantly normal faults, and is broken into five or so major, northwest tilted fault blocks whose hanging walls have folds with northwesterly trending axes [Wheeler, 1939; Schlische, 1992]. Subsequent erosion of these rotated fault blocks and folds, including about $2 \mathrm{~km}$ of section [Roden and Miller, 1991; Steckler et al., 1993], provides surface or near-surface access of much of the Newark Basin section.

A stratigraphic section was obtained by drilling in the rift basin sequence of the eastern and southeastern parts of central New Jersey (Figure 1b). The section was assembled from an array of seven relatively shallow $(\sim 800$ to $1200 \mathrm{~m})$ continuously cored drill holes. The drill holes intersected overlapping stratigraphic intervals along two transects (Figure 1c) to avoid drilling through the Palisade sill, a thick igneous intrusive unit. The regional $5^{\circ}$ to $15^{\circ}$ northwest formation dip made the offset drilling strategy possible.

Six of the drill sites were cored in late 1990 to early 1991 by Amoco Production Company using a closed circulation diamond coring system; on-site core analysis was provided by their automated Geological Evaluation Modules. The seventh drill site was cored in early 1993 by the Longyear Drilling Company. For those sites needing continuous core from the surface, New Jersey state regulations required the practice of drilling a shallow hole (well 2) from the surface to about $100 \mathrm{~m}$ to recover the cased interval in the immediately adjacent deep hole (well 1) that was cored from about $100 \mathrm{~m}$ to total depth. The 12 wells in the order cored were the Rutgers 1 and 2, Somerset 1 and 2, Titusville 1 and 2, Martinsville 1, Nursery 1, Princeton 1 and 2, and Weston 1 and 2. Correlation of wells 1 and 2 is unambiguous, and all the drill core sites are henceforth referred to by the locality name without further distinction of well number. Core depth was given by the drillers in decimal feet from the surface and marked directly on the core. The primary measurements are indexed to this footage which has been converted to metric units in reporting the stratigraphic results.

A total of $6770 \mathrm{~m}$ of $6.3-\mathrm{cm}$-diameter core was drilled at the seven coring sites (Table 1 ), including about $25 \%$ redundancy between the stratigraphically overlapping drill cores. Core recovery overall was virtually complete (better than $99 \%$ of the cored intervals), with only a small amount of undergauge and broken core. Supporting information was obtained from a full suite of slimhole geophysical logs [Goldberg et al., 1994]; the most pertinent logging data for the present study are the hole deviation survey and dipmeter logs which allow restoration of the drill core to the vertical and the tilted beds to the paleohorizontal frame of reference.

The cores span most of the Stockton Formation, all of the Lockatong Formation, Passaic Formation, and Orange Mountain Basalt, and practically all of the Feltville Formation (Figure 2). The stratigraphy of the Newark Basin used here follows the nomenclature of Olsen [1980] and is described fully by Olsen et al. [1995]; sedimentary facies and
Table 1. Newark Basin Coring Project Drill Site Parameters and Inventory of Paleomagnetic Samples by Dominant Lithology and Components Isolated

\begin{tabular}{|c|c|c|c|c|c|}
\hline \multirow[b]{2}{*}{ "Lithology" } & \multirow[b]{2}{*}{$N$} & \multicolumn{2}{|c|}{ Rejected } & \multicolumn{2}{|c|}{ Accepted } \\
\hline & & $\mathrm{A}$ or $\mathrm{B}$ & C & $n$ & $n / N \%$ \\
\hline \multicolumn{6}{|c|}{ Martinsville (40 $37^{\prime} 09^{\prime} N, 74^{\circ} 34^{\prime} 22^{\prime \prime} W, 1184 \mathrm{~m}$ Cored) } \\
\hline Red & 370 & 19 & 11 & 340 & 92 \\
\hline Basalt & 70 & & 0 & 70 & 100 \\
\hline \multicolumn{6}{|c|}{ 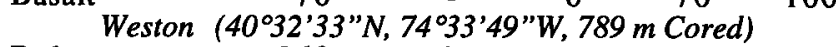 } \\
\hline Red & 260 & 1 & 13 & 246 & 95 \\
\hline \multicolumn{6}{|c|}{ Somerset $\left(40^{\circ} 30^{\prime} 31^{\prime \prime N}, 74^{\circ} 33^{\prime} 58^{\prime \prime} W, 914 \mathrm{~m}\right.$ Cored) } \\
\hline Red & $\begin{array}{r}330 \\
40.32\end{array}$ & $\begin{array}{c}6 \\
74 \% 6\end{array}$ & 15 & 309 & 94 \\
\hline Gray & $1+02$ & 0 & 0 & 2 & 100 \\
\hline Red & 338 & 3 & 1 & 334 & 99 \\
\hline Total & 340 & 3 & 1 & 336 & 99 \\
\hline \multicolumn{6}{|c|}{ Titusville (40'19'35"N, 74'51'02'W, $916 \mathrm{~m}$ Cored) } \\
\hline Gray & 85 & 1 & 24 & 60 & 71 \\
\hline Red & 278 & 10 & 20 & 248 & 89 \\
\hline Total & 363 & 11 & 44 & 308 & 85 \\
\hline \multicolumn{6}{|c|}{ Nursery $\left(40^{\circ} 18^{\prime} 03^{\prime \prime} \mathrm{N}, 7^{\circ} 49^{\prime} 27^{\prime \prime} \mathrm{W}, 914 \mathrm{~m}\right.$ Cored) } \\
\hline Gray-black & 197 & 29 & 58 & 110 & 56 \\
\hline Red-purple & 127 & 10 & 33 & 84 & 66 \\
\hline Total & 324 & 39 & 91 & 194 & 60 \\
\hline \multicolumn{6}{|c|}{ Princeton $\left(40^{\circ} 22^{\prime} 09^{\prime \prime} N\right.$ 74'36'49"W $1116 \mathrm{~m}$ Cored) } \\
\hline Gray-black & 54 & 10 & 23 & 21 & 39 \\
\hline Red/pink/buff & 351 & 85 & 59 & 207 & 59 \\
\hline Total & 405 & 95 & 82 & 228 & 56 \\
\hline \multicolumn{6}{|c|}{ All Seven Sites (6773 m Cored, $>99 \%$ Recovered) } \\
\hline Grayish & 338 & 40 & 105 & 193 & 57 \\
\hline Reddish & 2054 & 134 & 152 & 1768 & 86 \\
\hline Gray+Red & 2392 & 174 & 257 & 1961 & 82 \\
\hline Basalt & & 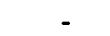 & 0 & $=0$ & 100 \\
\hline Total & 2462 & 174 & 257 & 2031 & 82 \\
\hline
\end{tabular}

Number of paleomagnetic samples measured, $N$, compared to those rejected on basis of poor overprint (A or B component) or characteristic (C component) magnetizations, and those accepted $(n)$ for magnetostratigraphic and paleopole analyses. Generalized lithologies described as basalt or by color of sediment.

depositional environments are discussed in more detail by Smoot [1991]. The Stockton Formation is the lowest stratigraphic unit and consists of buff-colored to red arkosic sandstones and siltstones of predominantly fluvial facies. The Lockatong Formation is dominated by gray to black shales with minor red siltstones and mudstones, interpreted as a relatively deep-water lacustrine facies. Red siltstones and mudstones become progressively more dominant in the overlying Passaic Formation and denote an overall shallowing lacustrine facies, although distinctive gray to black shale interbeds are still present. The Orange Mountain Basalt, the lowermost of the igneous extrusive units in the Watchung syncline, is a quartz-normative tholeiitic basalt consisting of three major lava flows. The overlying Feltville Formation shows a reversal in the upward shallowing/drier conditions of the Passaic and Lockatong Formations and consists of interbedded red and gray to black shales. The succeeding basaltic flows and sedimentary units of the Watchung syncline (Preakness Basalt, Towaco Formation, Hook Mountain Basalt, and Boonton Formation) were previously recovered in a series of shallow core holes by the Army Corp of Engineers [Fedosh and Smoot, 1988].

The sedimentary facies of the lacustrine Lockatong, Passaic and Feltville Formations have several orders of cyclic 
NEWARK BASIN CORING PROJECT

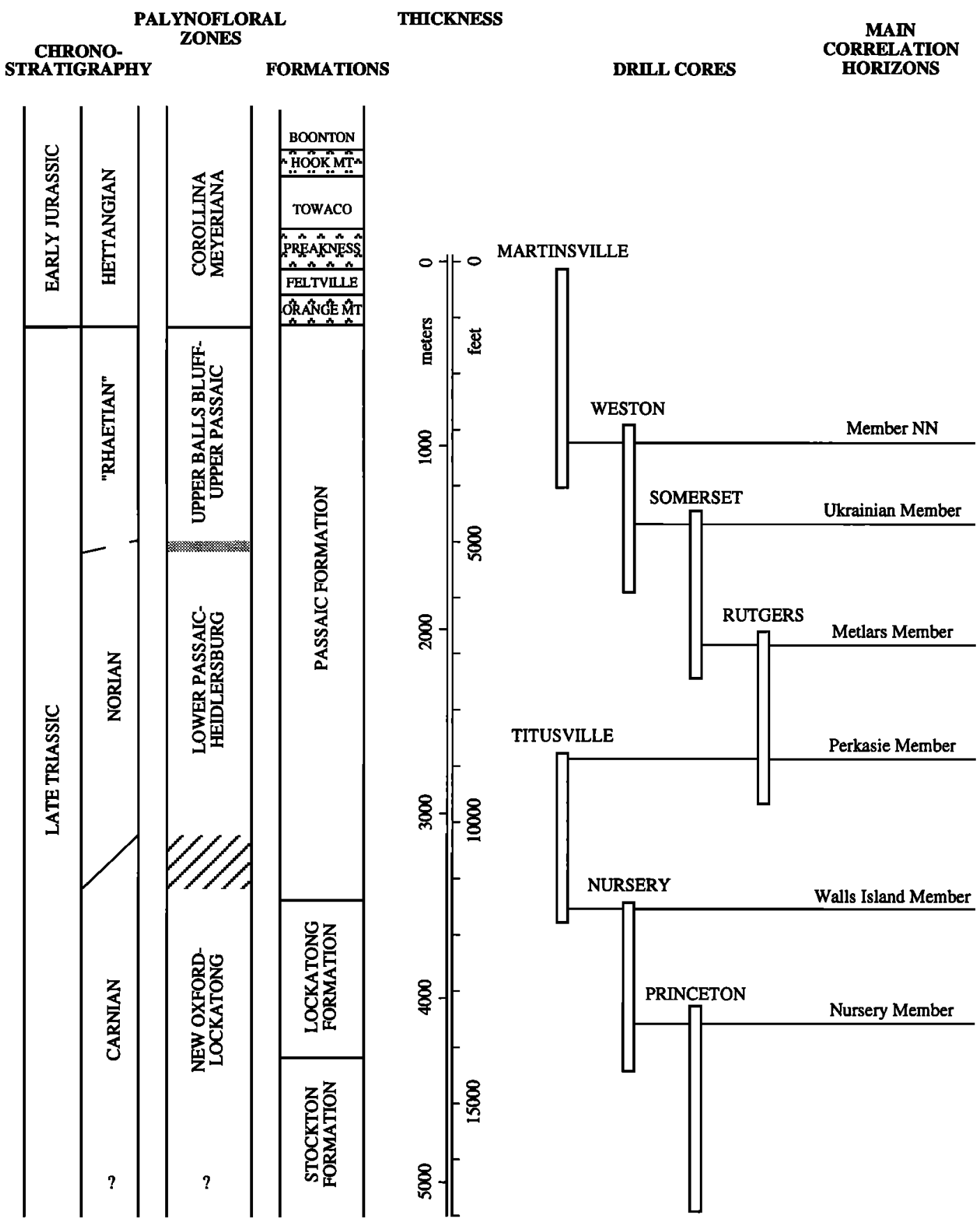

Figure 2. Stratigraphy of the Newark Basin and the section recovered by coring at the seven NBCP sites and a series of Army Corps of Engineers (ACE) cores [Fedosh and Smoot, 1988]. Thickness scale is the nominal aggregate length of stratigraphically overlapping NBCP drill cores linked by main correlation horizons. Palynofloral zonation is from Cornet [1977, 1993] and Cornet and Olsen [1985].

variation that are interpreted to represent climatically-induced changes in lake level reflecting Milankovitch orbital forcing [Van Houten, 1964; Olsen, 1986; Olsen and Kent, 1995]. The fundamental sedimentary variation is referred to as the Van Houten cycle, which is recognized on a stratigraphic scale of 3 to $6 \mathrm{~m}$ in the NBCP cores and consists of three divisions (Figure 3a). Division 1 is a relatively thin unit, generally massive at its base and becoming better bedded upward as the density of desiccation cracks and/or tubes (root or burrows) decreases. Division 2 has the best developed bedding in the cycle, commonly consisting of gray or black fissile mudstone. Division 3 becomes more massive upward by an increase in the frequency of desiccation cracks and/or tubes. Divisions 1 and 3 may be gray, purple, or red with lighter colors 


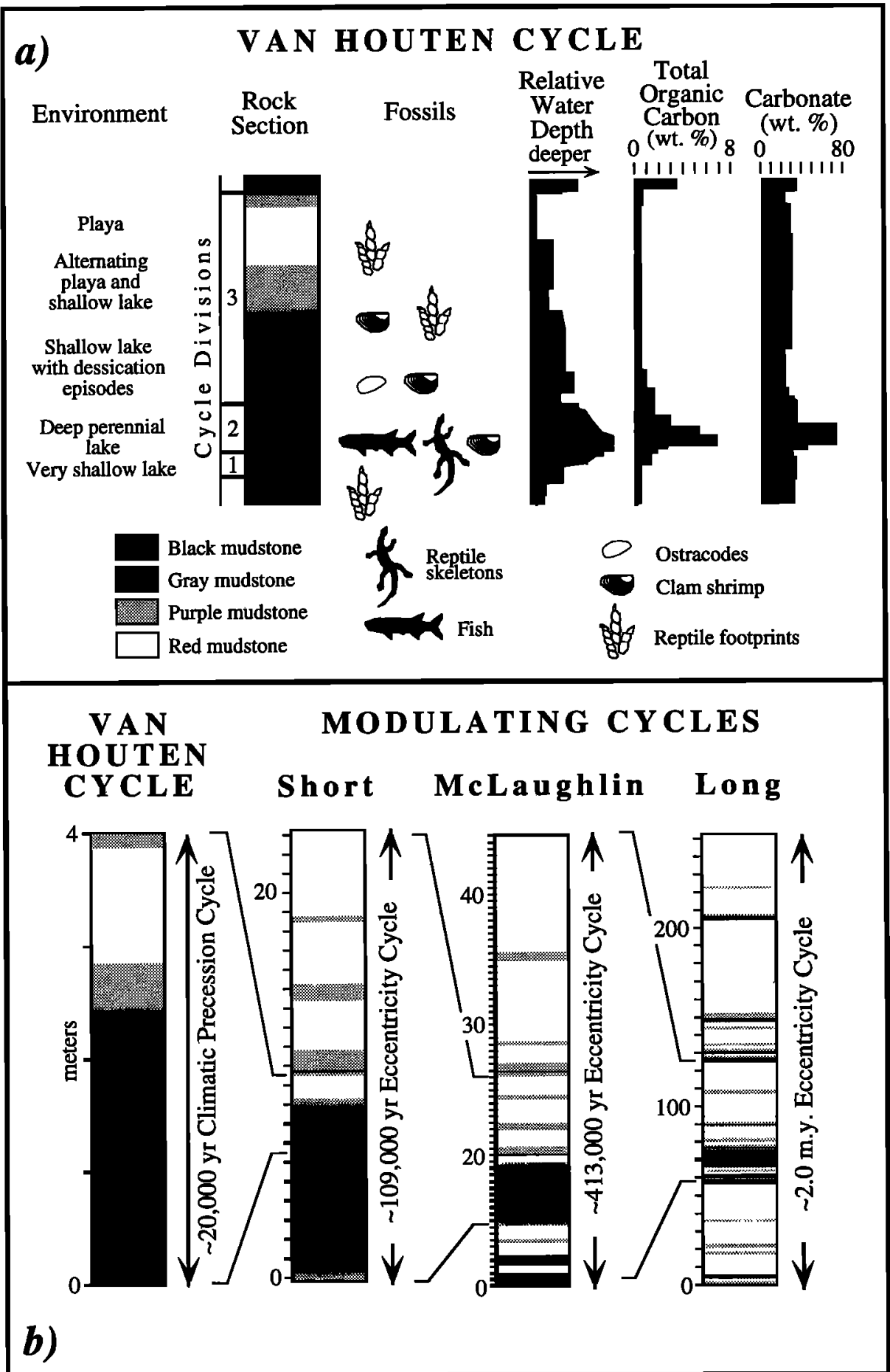

Figure 3. (a) Diagrammatic representation of a Van Houten cycle, showing the succession of lacustrine facies in the three divisions of the cycle and their paleoenvironmental interpretation. (b) Relationship of the Van Houten cycle and the short, McLaughlin, and long modulating cycles; nominal length scales and timescales are as interpreted in the NBCP drill cores.

predominating, while division 2 can be red, purple, gray, or black with darker colors being common. The tripartite division of the Van Houten cycle thus represents a deepeninghigh stand-shallowing sequence in relative lake level. Variations in Van Houten cycles in the NBCP cores are described in more detail by Smoot and Olsen [1994].

The expression of Van Houten cycles in terms of development of lamination and drab to black colors is modified by three orders of modulating cycles termed the short, intermediate or McLaughlin, and long cycles (Figure 3b). In the "peaks" of each of these modulating cycles, Van Houten cycles tend to be dominated by drab and dark colors; division 2 can be thick, black, and finely laminated, suggesting wetter climates and relatively deeper lakes. In the "troughs" of the modulating cycles, the Van Houten cycles tend to be mostly red; division 2 is usually red, purple, or gray fissile mudstone, 
suggesting drier climates with playas and shallow lakes. The hierarchy is such that short modulating cycles typically contain five Van Houten cycles, the McLaughlin cycles contain four short cycles, and the long cycles contain four to five McLaughlin cycles. The sedimentary expression of the long modulating cycles is the weakest, and that of the McLaughlin cycles is the strongest. Indeed, the McLaughlin cycles are effectively mappable lithostratigraphic units and provide the basis for subdivision of the Lockatong and Passaic Formations into 53 members for precise correlation within the basin [Olsen et al., 1995].

Cornet [1977, 1993] and Cornet and Olsen [1985] recognized four pollen and spore zones in the Newark Basin section (Figure 2). These provide the best presently available ties to standard geologic ages, and the age assignments are generally supported by vertebrate assemblages from the Newark Supergroup [Olsen and Galton, 1977, 1984; Olsen et al., 1982; Cornet and Olsen, 1985; Olsen et al., 1987; Lucas and Huber, 1993; Huber et al., 1993]. The Stockton and Lockatong Formations are of Carnian age, although there are hardly any age diagnostic fossils in the lower and middle Stockton Formation. Assemblages belonging to the New Oxford-Lockatong palynofloral zone of late Carnian age occur in the upper Stockton Formation, the Lockatong Formation, and up to member C (called member B by Cornet [1977]) in the lowermost Passaic Formation. The Carnian/Norian boundary should lie between member $\mathrm{C}$ and the Graters Member in the lower Passaic Formation where the lowest assemblage of the Lower Passaic-Heidlersburg palynofloral zone of Norian age occurs. Parenthetically, the level of the Carnian/Norian boundary was incorrectly drawn by Witte et al. [1991], as already discussed by Lucas et al. [1993] and Witte et al. [1993].

Two other palynofloral boundaries occur in the Passaic Formation. The Lower Passaic-Heidlersburg palynofloral zone extends to member FF and is succeeded in the lower Cedar Hill Member by the Upper Balls Bluff-Upper Passaic palynofloral zone (renamed from Manassas-Upper Passaic by Litwin et al. [1991]). This palynofloral change may approximate the level of the Norian/Rhaetian boundary, although criteria for recognition of the "Rhaetian" are very uncertain [e.g., Tozer, 1993]. The Triassic/Jurassic boundary is placed within the Exeter Member in the uppermost Passaic Formation, $20 \mathrm{~m}$ below the contact with the Jacksonwald Basalt that is correlative to the Orange Mountain Basalt, based on the welldefined transition from the Upper Balls Bluff-Upper Passaic palynofloral zone to the Corollina meyeriana palynofloral zone [Fowell and Olsen, 1993; Fowell et al., 1994]. A spike in the spore/pollen ratio is found to be coincident with a regional extinction of more than half of the palynoflora at the Triassic/Jurassic boundary which is also closely associated with terrestrial vertebrate extinctions [Olsen and Sues, 1986; Olsen et al., 1990; Silvestri and Szajna, 1993; Szajna and Hartline, 1995]. An assemblage of the Corollina meyeriana palynofloral zone can be found just below the Boonton fish bed of the Boonton Formation [Olsen, 1980], suggesting that the overlying igneous extrusive sequence and interbedded sediments are all within the Hettangian (earliest Jurassic).

Concordant radiometric dates are available from the Palisade sill within the Newark Basin. The sill provides a ${ }^{40} \mathrm{Ar} /{ }^{39} \mathrm{Ar}$ date on biotite from a xenolith of $202 \pm 1 \mathrm{Ma}$ [Sutter, 1988] and $\mathrm{U}-\mathrm{Pb}$ dates from zircon and baddeleyite of

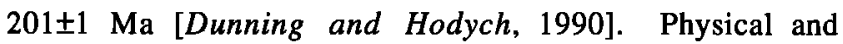
geochemical relationships show that the Palisade sill is most likely contemporaneous with the Preakness Basalt [Kodama, 1983; Ratcliffe, 1988].

\section{Sampling and Laboratory Procedures}

A paleomagnetic sample plug was taken from what we judged to be the most favorable lithology within each core storage box (nominal $3 \mathrm{~m}$ interval). Most of the samples were from red sediments, but all lithologies including gray to black shales and the basalts were included as part of the regular sampling scheme. The sample plugs consisted of $2.5-\mathrm{cm}-$ diameter cylinders drilled perpendicular to the core axis, inscribed in the upcore direction, and sliced into $2.2 \mathrm{~cm}$ long $\left(\sim 11 \mathrm{~cm}^{3}\right)$ specimens for paleomagnetic measurements.

The specimens were stored, and demagnetization treatments and measurements of their natural remanent magnetization (NRM) were made within a low magnetic field environment $(<300 \mu \mathrm{T})$ of a shielded room. On the basis of pilot studies on core samples and our previous work on outcrop samples [e.g., Witte and Kent, 1989], progressive thermal demagnetization was found to be the preferred treatment to separate components of NRM in the hematite-bearing (i.e., high coercivity) red sediments that dominate much of the section. The same treatment also worked well for the gray to black shales and the basalts. Heating and forced air cooling were done in a specially built large-capacity (51 specimen) thermal demagnetizer in which local shielding reduced ambient magnetic fields to less than $5 \mu \mathrm{T}$ and noninductively wound main and end furnaces kept thermal gradients to less than $5^{\circ} \mathrm{C}$ over the volume occupied by the specimens. The magnetic remanence of the specimens, typically of the order $10 \mathrm{~mA} / \mathrm{m}$ for the sediments and $10 \mathrm{~A} / \mathrm{m}$ for the basalts, was measured with a ScT two-axis cryogenic magnetometer and, for the last (Weston) drill core, a 2G Model 760 three-axis cryogenic magnetometer. A redundant measurement scheme that provided an estimate of measurement precision of the remanence vector [Lowrie et al., 1980] was used as a basis for rejection of poor quality data, especially at higher levels of demagnetization. The low-field magnetic susceptibility of each specimen was measured routinely after each thermal treatment step with a Bartington instrument to monitor effects of magnetochemical alteration over the course of the demagnetization procedure.

Two alternative schedules of thermal treatment were used. For specimens from red lithologies, where hematite was the expected principal carrier of remanence, thermal demagnetization was done in a minimum of nine steps, usually at $200^{\circ}, 300^{\circ}, 400^{\circ}, 500^{\circ}, 600^{\circ}, 650^{\circ}, 660^{\circ}, 670^{\circ}, 675^{\circ}$, and $/$ or $680^{\circ} \mathrm{C}$. For the gray to black shales, as well as the basalts, in which magnetite was the expected carrier of the remanence, the typical thermal demagnetization schedule was at $200^{\circ}, 300^{\circ}, 350^{\circ}, 400^{\circ}, 450^{\circ}, 500^{\circ}, 520^{\circ}, 540^{\circ}, 560^{\circ}, 5700^{\circ}$ $575^{\circ}$, and/or $580^{\circ} \mathrm{C}$. If the "red" schedule resulted in a large decrease in NRM intensity between $500^{\circ}$ and $600^{\circ} \mathrm{C}$, and the presence of a magnetite component was therefore suspected, the companion specimen was subjected to the "gray" thermal treatment schedule. Conversely, if there was appreciable remanence remaining after the conclusion of the "gray" schedule, thermal treatment was continued using the "red" schedule from $600^{\circ}$ to $680^{\circ} \mathrm{C}$. The systematic thermal demagnetization schedules were convenient in processing data 
a)
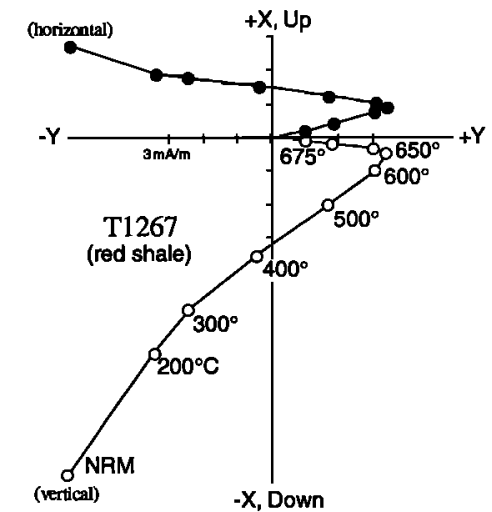

b)

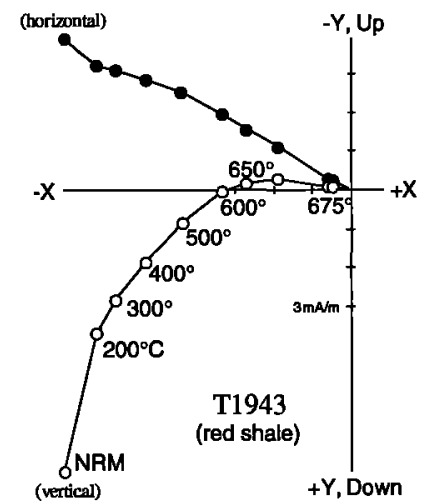

c)

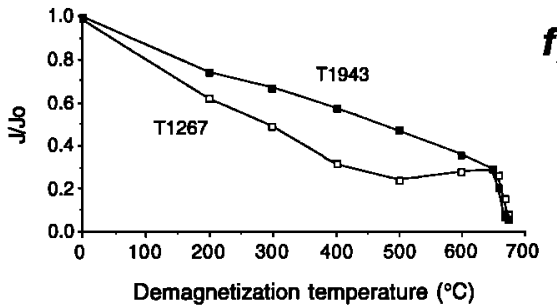

d)

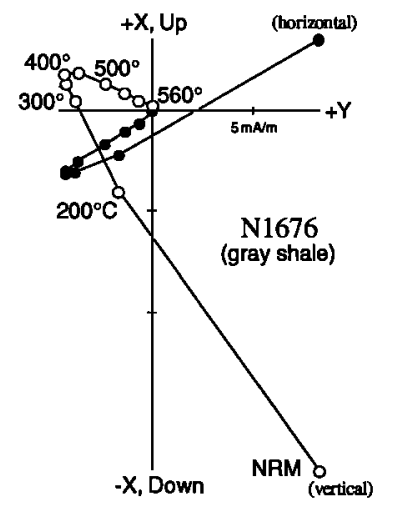

e)

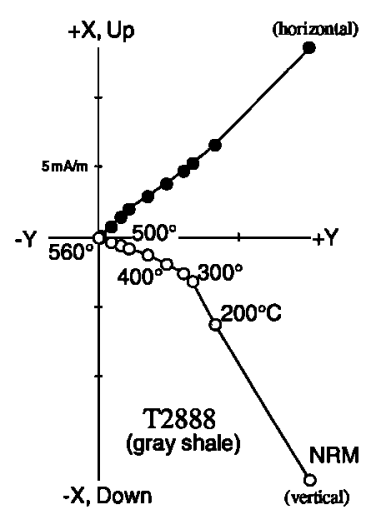

f)

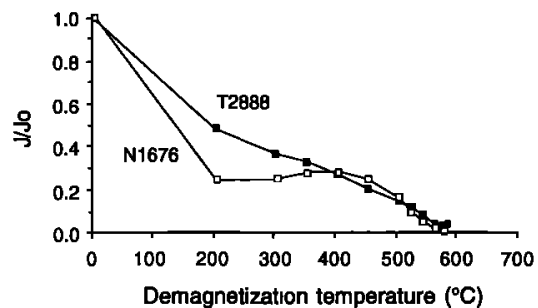

g)

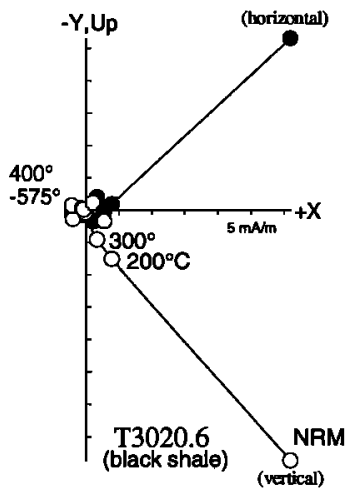

h)

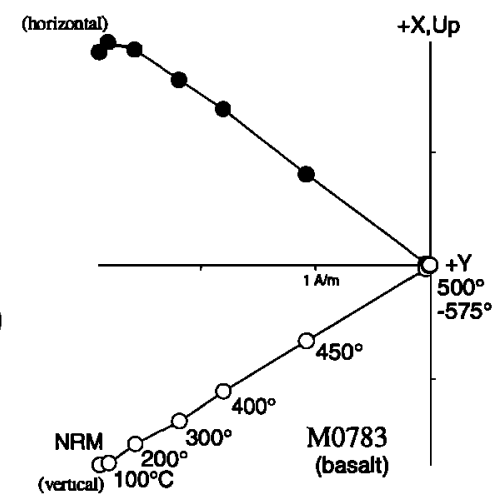

i)

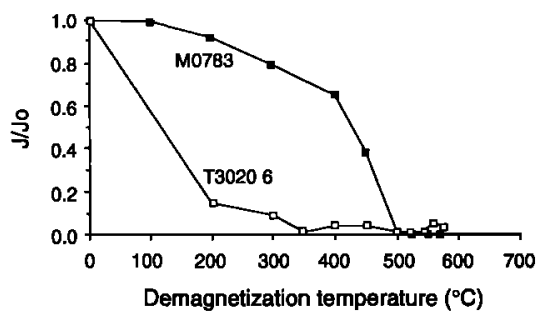

Figure 4. Vector end-point diagrams and normalized decay curves illustrating thermal demagnetization of NRM of representative samples and lithologies from NBCP drill cores. Horizontal coordinates have arbitrary azimuth; vertical coordinates correspond to drill core axis. Samples are identified with first letter of drill site and footage.

for magnetization components in the more than 2400 samples analyzed in this study.

\section{Magnetic Properties}

The NRM of the red sediments generally consists of three components of magnetization (Figures $4 a-4 c$ ), similar to the component structure that has been described from outcrop studies of this lithology [e.g., Witte and Kent, 1989]. Component $\mathrm{A}$ is ascribed to a present-day viscous overprint that is usually of small magnitude and readily removed by $300^{\circ} \mathrm{C}$. Component $\mathrm{B}$ is an ubiquitous ancient secondary magnetization with a moderate and uniformly downward inclination; it is of highly variable magnitude and revealed as a linear demagnetization trajectory with unblocking temperatures distributed from about $300^{\circ}$ to $600^{\circ}$ or sometimes $650^{\circ} \mathrm{C}$. Component $\mathrm{Ch}$ is regarded as the characteristic magnetization and is usually isolated over a discrete unblocking temperature range from $650^{\circ}$ to $675^{\circ}$ or $680^{\circ} \mathrm{C}$ and has a shallow direction with a declination that is nearly either parallel or antiparallel with respect to that of the B component.

The NRM of the gray to black shales usually consists of only two components (Figures $4 d-4 f$ ). First removed with a maximum unblocking temperature of $300^{\circ}$ to sometimes $400^{\circ} \mathrm{C}$ is a steep downward magnetization which we identify as a recent overprint and refer to as the A component. A magnetization with moderate downward direction, analogous to the B component of the red sediments, is evidently not present in the magnetite-bearing gray shales. Instead, the remaining magnetization usually converges toward the origin by $560^{\circ}$ to $575^{\circ} \mathrm{C}$ and has a shallow direction with a declination that roughly either parallels or is opposite to that of the A component; we regard this $\mathrm{Cm}$ component as the characteristic magnetization of the gray to black shales.

A subset of the gray to black shales showed, at best, only a single linear trajectory that converged to the origin by about $300^{\circ} \mathrm{C}$ (Figure $4 \mathrm{~g}$ ). The steep, downward inclination suggests acquisition of this component $(A)$ in the present-day field. Demagnetization to higher temperatures yielded scattered 
directions; hence no identifiable component of ancient origin is apparently present in these samples.

The NRM of the Orange Mountain Basalt typically showed univectorial demagnetization behavior over most of the unblocking temperature spectrum to $500^{\circ}$ to $550^{\circ} \mathrm{C}$ (Figures $4 \mathrm{~h}$ and $4 \mathrm{i}$ ), indicative of a low-Ti titanomagnetite carrier of the remanence. Contributions from less stable components are typically small or not systematically aligned from sample to sample. By analogy with the magnetization of the Orange Mountain Basalt in outcrop [e.g., Mclntosh et al., 1985; Witte and Kent, 1990], the stable univectorial remanence in the drill core samples is regarded as the characteristic component.

Least squares line fits [Kirschvink, 1980] were used to calculate the component directions from selected segments of the vector plots for each specimen. For the red sediments, estimates of the $B$ component were obtained using data typically from four demagnetization steps between $300^{\circ}$ and $600^{\circ} \mathrm{C}$, and the $\mathrm{Ch}$ component from four demagnetization steps between $650^{\circ}$ and $675^{\circ} / 680^{\circ}$ anchored to the origin. For the gray shales (and basalt), estimates of the A component were typically based on three levels to $300^{\circ}$ or $350^{\circ} \mathrm{C}$, and the $\mathrm{Cm}$ component from an average of four demagnetization steps in the interval of $400^{\circ} \mathrm{C}$ and $575^{\circ} \mathrm{C}$ anchored to the origin. Component estimates with a maximum angular deviation (MAD) greater than $20^{\circ}$ were rejected.

Isothermal remanent magnetization (IRM) experiments support the broad, lithologic-dependent categorization of magnetic carriers in the sediments based on NRM properties. The IRM of the red sediments does not reach saturation by $1 \mathrm{~T}$ and shows a regular unblocking temperature spectra to about $680^{\circ} \mathrm{C}$ (Figure 5a); these properties signify hematite as the principal, and in most cases sole, magnetic mineral. The IRM of the gray shales typically reaches saturation by about $0.2 \mathrm{~T}$ and has a smooth unblocking temperature spectrum to about $570^{\circ} \mathrm{C}$ (Fig 5b), properties that conform to magnetite as the dominant magnetic mineral. Mixtures of magnetite and hematite were only occasionally encountered in thin zones between the red and gray shale lithologies. Some of the gray to black shales show evidence of a large IRM fraction with unblocking temperatures of about $350^{\circ} \mathrm{C}$, often in addition to a magnetite component (Figure 5c). These properties correspond to those samples with no resolvable hightemperature components of NRM (e.g., Figure $4 \mathrm{~g}$ ) and suggest the presence of pyrrhotite or perhaps greigite [e.g., Reynolds et al., 1994] as an important magnetic carrier in the most reduced parts of the gray to black shale units.

Magnetic susceptibility of samples from the Lockatong, Passaic, and Feltville Formations typically showed very large increases after heating to moderate to high temperatures, starting at about $550^{\circ} \mathrm{C}$ in the red and gray shales but by about $400^{\circ} \mathrm{C}$ in the darker gray to black shales (Figure 5). The growth of a highly magnetic phase may be related to alteration of clays or perhaps the oxidation of sulphides that are disseminated in much of the lacustrine sediments. In the red sediments, some of the original hematite may also have become reduced during heating (i.e., the interiors of red specimens tended to become dark gray to black after thermal treatment) and in the process contributed to the generation of a higher susceptibility phase. Thermally induced susceptibility increases were more modest for red sediment samples from outcrop [e.g., Witte and Kent, 1989], perhaps because any sulphides had been weathered out of the surficial rocks. In any
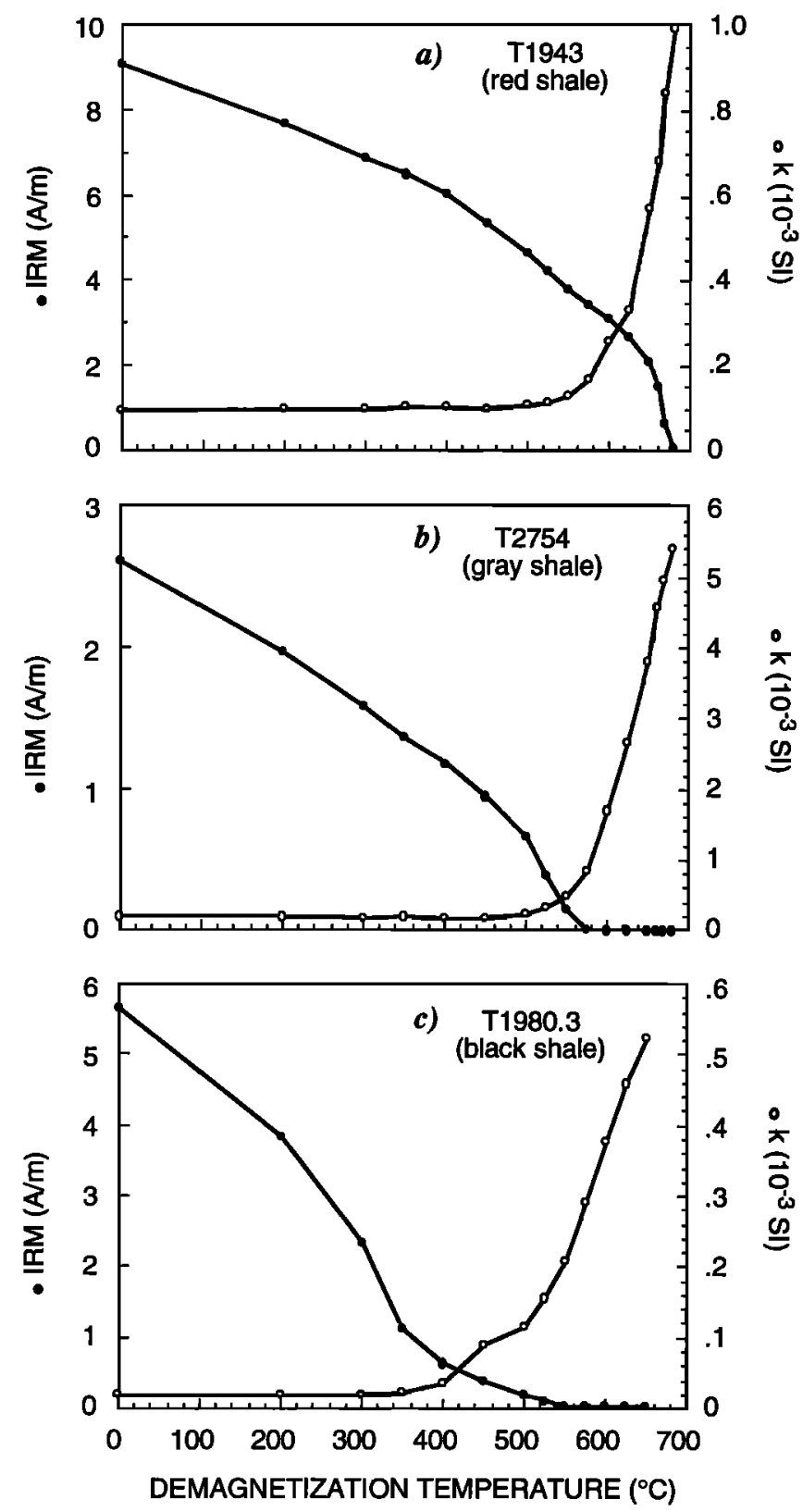

Figure 5. Thermal demagnetization of IRM (1 T) of representative sedimentary samples from NBCP drill cores. Samples are identified with first letter of drill site and footage.

case, a low magnetic field environment over the course of thermal demagnetization of NRM is important to minimize the acquisition of spurious magnetizations by the strongly magnetic alteration phases in these rocks.

\section{Core and Bedding Orientation}

Data from fully oriented samples from outcrop show that the characteristic magnetizations of Newark sedimentary rocks have shallow inclinations in paleohorizontal coordinates [e.g., Witte et al., 1991]. Declination is therefore needed to determine polarity unambiguously, but this requires a known azimuthal reference.

The NBCP drill cores were not oriented in azimuth during drilling because of the prohibitive expense that this would 
Table 2. NBCP Down Hole Orientation Data

\begin{tabular}{|c|c|c|c|c|}
\hline \multirow[b]{2}{*}{$\begin{array}{c}\text { Log } \\
\text { Depth, m }\end{array}$} & \multicolumn{2}{|c|}{ Hole Deviation } & \multicolumn{2}{|c|}{ Dipmeter } \\
\hline & $\begin{array}{l}\text { DAz, } \\
\text { deg }\end{array}$ & $\begin{array}{l}\text { DVt, } \\
\text { deg }\end{array}$ & $\begin{array}{c}\text { BAz, } \\
\text { deg }\end{array}$ & $\begin{array}{c}\text { BDp, } \\
\text { deg }\end{array}$ \\
\hline \multicolumn{5}{|c|}{ Martinsville $1^{\mathrm{a}}$} \\
\hline 61.0 & 188.0 & 2.0 & 43.0 & 4.2 \\
\hline 152.4 & 199.0 & 3.5 & 43.0 & 4.1 \\
\hline 182.9 & 200.0 & 3.9 & 43.0 & 4.1 \\
\hline 304.8 & 203.0 & 3.8 & 43.0 & 5.3 \\
\hline 335.3 & 204.0 & 3.7 & 43.0 & 5.7 \\
\hline 457.2 & 211.0 & 3.6 & 44.0 & 5.7 \\
\hline 609.6 & 219.0 & 3.3 & 45.0 & 5.7 \\
\hline 762.0 & 225.0 & 3.0 & 46.0 & 5.7 \\
\hline 914.4 & 231.0 & 2.7 & 47.0 & 5.8 \\
\hline 1066.8 & 238.0 & 2.8 & 47.0 & 5.8 \\
\hline 1219.2 & 245.0 & 2.9 & 48.0 & 5.8 \\
\hline 1223.8 & 245.0 & 2.9 & 48.0 & 5.8 \\
\hline \multicolumn{5}{|c|}{ Weston 1 and 2} \\
\hline 0.0 & 180.0 & 0.0 & 335.0 & 3.5 \\
\hline 45.7 & 180.0 & 1.4 & 333.0 & 3.5 \\
\hline 91.4 & 173.0 & 1.8 & 330.0 & 3.5 \\
\hline 152.4 & 170.0 & 2.2 & 328.0 & 4.0 \\
\hline 243.8 & 171.0 & 2.8 & 321.0 & 6.0 \\
\hline 304.8 & 178.0 & 3.5 & 331.0 & 6.0 \\
\hline 457.2 & 183.0 & 4.8 & 341.0 & 6.0 \\
\hline 563.9 & 185.0 & 5.2 & 340.0 & 7.0 \\
\hline 609.6 & 188.0 & 5.4 & 338.0 & 7.0 \\
\hline 762.0 & 193.0 & 6.0 & 333.0 & 7.0 \\
\hline 794.3 & 193.0 & 6.2 & 332.0 & 7.0 \\
\hline \multicolumn{5}{|c|}{ Somerset 1 and 2} \\
\hline 0.0 & 0.0 & 0.0 & 338.0 & 6.4 \\
\hline 24.4 & 120.0 & 0.6 & 336.0 & 6.5 \\
\hline 42.7 & 90.0 & 0.9 & 336.0 & 6.7 \\
\hline 54.9 & 110.0 & 1.2 & 336.0 & 6.8 \\
\hline 91.1 & 120.0 & 2.0 & 336.0 & 6.9 \\
\hline 91.4 & 95.0 & 1.7 & 336.0 & 6.9 \\
\hline 152.4 & 108.0 & 2.4 & 335.0 & 7.0 \\
\hline 225.6 & 125.0 & 2.7 & 334.0 & 7.1 \\
\hline 304.8 & 140.0 & 3.6 & 332.0 & 7.2 \\
\hline 335.3 & 147.0 & 3.9 & 331.0 & 7.5 \\
\hline 457.2 & 145.0 & 5.0 & 329.0 & 7.8 \\
\hline 609.6 & 148.0 & 5.8 & 328.0 & 8.2 \\
\hline 762.0 & 150.0 & 6.1 & 322.0 & 8.7 \\
\hline 914.4 & 153.0 & 7.2 & 320.0 & 9.1 \\
\hline 917.4 & 153.0 & 7.2 & 320.0 & 9.1 \\
\hline \multicolumn{5}{|c|}{ Rutgers $1^{\mathrm{b}}$} \\
\hline 91.4 & 143.0 & 2.4 & 320.0 & 10.0 \\
\hline 152.4 & 138.0 & 3.0 & 320.0 & 10.0 \\
\hline 274.3 & 142.0 & 4.0 & 320.0 & 10.0 \\
\hline 304.8 & 144.0 & 4.5 & 320.0 & 10.0 \\
\hline 426.7 & 144.0 & 6.4 & 320.0 & 10.0 \\
\hline 457.2 & 144.0 & 6.4 & 320.0 & 10.0 \\
\hline 579.1 & 148.0 & 6.5 & 320.0 & 10.0 \\
\hline 609.6 & 146.0 & 6.5 & 320.0 & 10.0 \\
\hline 762.0 & 143.0 & 7.4 & 320.0 & 10.0 \\
\hline 914.4 & 140.0 & 7.8 & 320.0 & 10.0 \\
\hline 943.4 & 140.0 & 8.2 & 320.0 & 10.0 \\
\hline 944.9 & 140.0 & 8.2 & 320.0 & 10.0 \\
\hline \multicolumn{5}{|c|}{ Titusville 1 and 2} \\
\hline 0.0 & 164.0 & 0.0 & 337.0 & 8.8 \\
\hline 30.5 & 164.0 & 0.0 & 335.0 & 8.8 \\
\hline 91.1 & 164.0 & 2.7 & 331.0 & 8.8 \\
\hline 91.4 & 162.0 & 6.1 & 331.0 & 8.8 \\
\hline 152,4 & 163.0 & 6.6 & 327.0 & 8.8 \\
\hline 182.9 & 164.0 & 6.7 & 325.0 & 8.8 \\
\hline 243.8 & 166.0 & 6.6 & 325.0 & 8.8 \\
\hline 304.8 & 166.0 & 7.1 & 325.0 & 8.8 \\
\hline 353.6 & 168.0 & 7.4 & 325.0 & 8.8 \\
\hline 457.2 & 170.0 & 7.0 & 326.0 & 8.5 \\
\hline 548.6 & 176.0 & 7.0 & 326.0 & 8.3 \\
\hline
\end{tabular}

Table 2. (continued)

\begin{tabular}{|c|c|c|c|c|}
\hline \multirow[b]{2}{*}{$\begin{array}{c}\text { Log } \\
\text { Depth, m }\end{array}$} & \multicolumn{2}{|c|}{ Hole Deviation } & \multicolumn{2}{|c|}{ Dipmeter } \\
\hline & $\begin{array}{c}\text { DAz, } \\
\text { deg }\end{array}$ & $\begin{array}{l}\text { DVt, } \\
\text { deg }\end{array}$ & $\begin{array}{c}\text { BAz, } \\
\text { deg }\end{array}$ & $\begin{array}{r}\text { BDp, } \\
\text { deg }\end{array}$ \\
\hline & \multicolumn{3}{|c|}{ Titusville 1 and 2 (continued) } & \\
\hline 609.6 & 175.0 & 7.0 & 327.0 & 8.1 \\
\hline 670.6 & 175.0 & 7.3 & 327.0 & 8.0 \\
\hline 762.0 & 173.0 & 6.6 & 328.0 & 7.8 \\
\hline 914.4 & 173.0 & 6.2 & 330.0 & 7.4 \\
\hline \multirow[t]{2}{*}{924.5} & 173.0 & 6.2 & 330.0 & 7.4 \\
\hline & \multicolumn{3}{|c|}{ Nursey $l^{\mathrm{a}}$} & \\
\hline 91.4 & 152.0 & 2.7 & 351.0 & 11.0 \\
\hline 152.4 & 157.0 & 4.6 & 352.0 & 11.0 \\
\hline 213.4 & 163.0 & 6.5 & 352.0 & 10.9 \\
\hline 304.8 & 170.0 & 6.6 & 353.0 & 10.8 \\
\hline 426.7 & 172.0 & 6.8 & 355.0 & 9.5 \\
\hline 457.2 & 173.0 & 6.8 & 356.0 & 10.1 \\
\hline 518.2 & 174.0 & 7.1 & 357.0 & 11.2 \\
\hline 566.9 & 176.0 & 7.5 & 358.0 & 12.0 \\
\hline 609.6 & 177.0 & 7.7 & 359.0 & 11.8 \\
\hline 731.5 & 184.0 & 8.4 & 4.0 & 10.7 \\
\hline 762.0 & 186.0 & 8.5 & 5.0 & 10.3 \\
\hline 914.4 & 186.0 & 8.7 & 15.0 & 9.2 \\
\hline \multirow[t]{2}{*}{1007.4} & 182.0 & 8.0 & 18.0 & 8.5 \\
\hline & \multicolumn{3}{|c|}{ Princeton 1 and $2^{\mathrm{c}}$} & \\
\hline 0.0 & 160.0 & 0.5 & 358.0 & 14.0 \\
\hline 61.0 & 160.0 & 0.5 & 358.0 & 14.0 \\
\hline 96.6 & 160.0 & 1.5 & 358.0 & 14.0 \\
\hline 96.9 & 165.0 & 3.0 & 358.0 & 14.0 \\
\hline 152.4 & 165.0 & 4.5 & 358.0 & 14.0 \\
\hline 243.8 & 165.0 & 7.0 & 358.0 & 14.0 \\
\hline 304.8 & 166.0 & 7.4 & 358.0 & 14.0 \\
\hline 457.2 & 170.0 & 8.8 & 358.0 & 14.0 \\
\hline 609.6 & 175.0 & 9.4 & 358.0 & 14.0 \\
\hline 722.4 & 170.0 & 9.2 & 358.0 & 14.0 \\
\hline 762.0 & 170.0 & 9.0 & 358.0 & 14.0 \\
\hline 914.4 & 170.0 & 9.0 & 358.0 & 14.0 \\
\hline 1066.8 & 170.0 & 9.0 & 358.0 & 14.0 \\
\hline 1127.8 & 170.0 & 9.0 & 358.0 & 14.0 \\
\hline
\end{tabular}

$\mathrm{DAz}$ is the azimuth of $\mathrm{DVt}$, the angular deviation of the hole from true vertical, and BAz is the azimuth of BDp, the dip of bedding, picked from continuous down hole logging data described by Goldberg et al. [1994] and used for interpolation at other depths.

a Well 2 not drilled.

b Rutgers 2 drilled but not logged; hole deviation and bedding assumed constant to $91.4 \mathrm{~m}$.

c Assuming hole deviation and bedding is constant below $722.4 \mathrm{~m}$ where not logged.

have entailed. Borehole dipmeter logs show bedding attitudes that dip from $5^{\circ}$ (Martinsville) to $15^{\circ}$ (Princeton) toward the north (Table 2 ), so that core-bedding plane intersections could conceivably provide a means to retrieve an azimuthal reference, as in the study of the relatively shallow Army Corps of Engineer drill cores [Witte and Kent, 1990]. However, the deeper NBCP boreholes had a tendency to deviate progressively with depth into the bedding updip (southerly) direction (Table 2), bringing the already shallow dipping bedding planes even closer to perpendicular to the core axis. This method of core orientation could therefore not be generally used in the NBCP drill cores.

The ubiquitous presence of an overprint magnetization (A or $B$ component) provided an alternative means to determine azimuthal orientation that proved successful. The A or B magnetization components were generally well defined, with a 
median MAD value of about $3^{\circ}$ in each drill core; only about $7.5 \%$ of the 2392 total sediment samples did not provide useful estimates of one of these overprint magnetization directions (Table 1). In the red sediments, we assume that the $B$ component isolated in the drill core samples is the same as the B component identified in outcrop. The B component in fully oriented samples from 50 outcrop sites distributed over the Newark Basin is of uniform normal polarity and has a mean direction in geographic coordinates of $D=3^{\circ}, I=42^{\circ}$ [Witte and Kent, 1991]. Because the gray shale samples evidently do not have a $B$ component, we use the A component for orienting these drill core samples, assuming that it represents a magnetization acquired along the present dipole field $\left(D=0^{\circ}\right.$, $\left.I=59^{\circ}\right)$. The steep to moderate positive inclinations of the A and the $\mathrm{B}$ components provide a criterion additional to unblocking temperature spectra for distinguishing these overprints from the dual-polarity, shallow characteristic component in the drill core samples. The overprints were also useful to flag the small number of drill core segments that had been inadvertently inverted (as confirmed by core catcher marks and matching of broken ends) during the around-theclock coring operations.
The orientation of each sample was determined by the following procedure. The expected overprint direction was projected into the deviated hole reference frame according to the downhole orientation logs (Table 2). The sample reference frame was then rotated about the deviated drill core axis until the sample A or B component declination coincided with the projected declination of the expected direction. To obtain sample directions in geographic coordinates, the rotated sample reference frame is simply adjusted for the small borehole deviation; to obtain sample directions with respect to the paleohorizontal or bedding coordinates, the geographic coordinate reference frame is corrected for the bedding tilt as measured in the downhole dipmeter survey (Table 2).

\section{Analyses of Secondary and Characteristic Magnetizations}

The use of overprints or secondary magnetizations for azimuthal orientation requires that they have been properly isolated in the drill core samples and correspond on average to a known direction. From a practical standpoint, overprint directions nearly parallel to the drill core axis do not provide
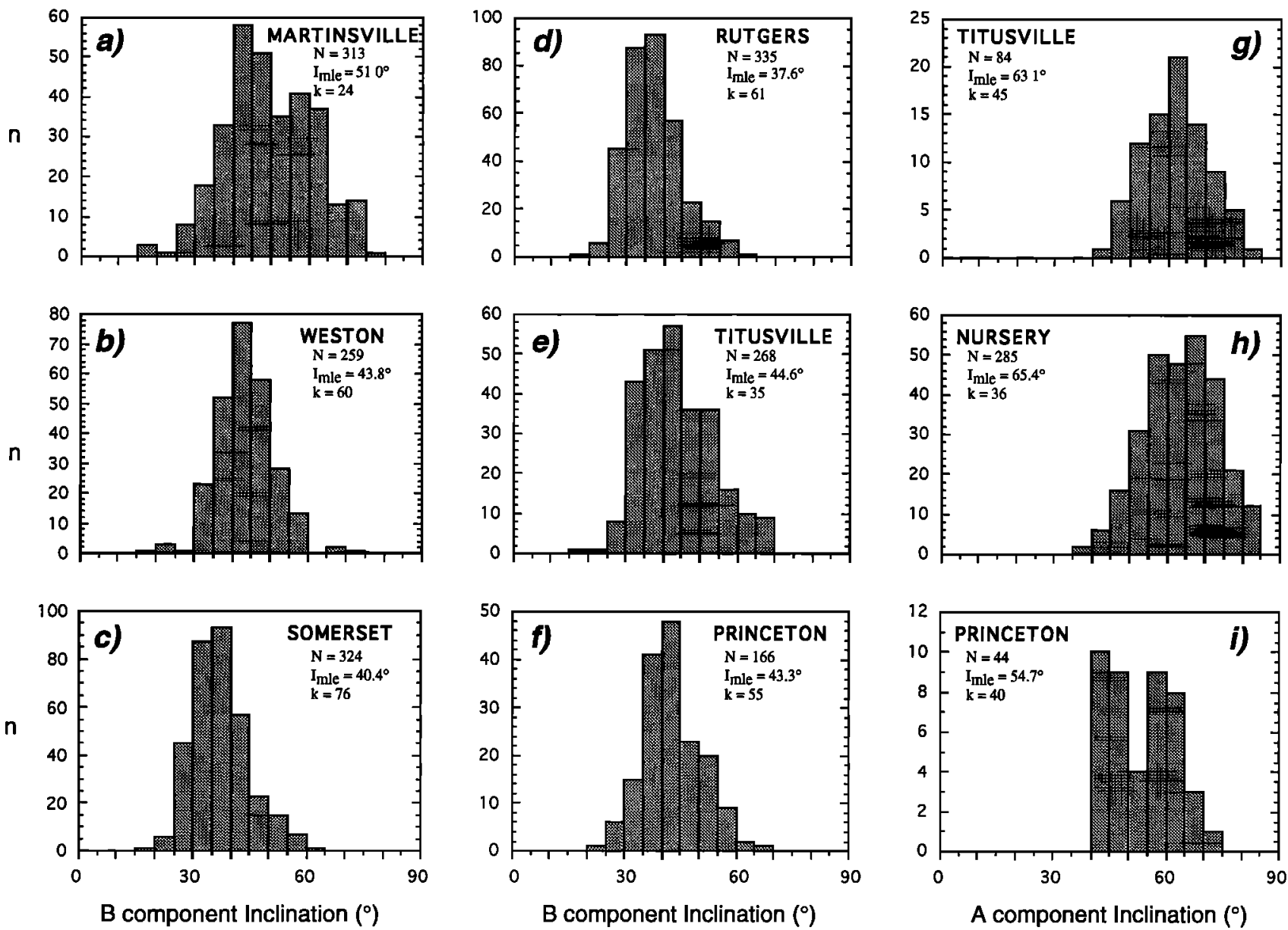

Figure 6. Inclinations of overprint magnetizations ((a)-(f) B component; (g)-(i) A component) isolated in samples from NBCP drill cores. Maximum likelihood estimates for mean inclination (Imle) and precision parameter $(k)$ calculated using technique of McFadden and Reid [1982; corrected algorithm from Schneider, 1989] on inclinations with respect to present horizontal (i.e., drill cores corrected only for hole deviation). Expected inclination for B component is $42^{\circ}$ [Witte and Kent, 1991] and for A component is dipole field local value of $59^{\circ}$. 
very useful azimuthal orientation information; accordingly, we rejected samples with overprint magnetization inclinations greater than $75^{\circ}$ in the drill core reference frame. We also rejected samples with a magnetization direction shallower than $15^{\circ}$ over the expected unblocking temperature range of the $\mathrm{A}$ or B component; such samples are likely to have a poorly developed overprint magnetization that is difficult to distinguish from the characteristic component. Only a small number of samples were rejected for these reasons and have already been included in the overall statistics shown in Table 1 .

Mean values of inclination and estimates of Fisher's precision parameter for the $\mathrm{A}$ and/or $\mathrm{B}$ components were calculated for each drill core according to a maximum likelihood method for inclination-only data [McFadden and Reid, 1982; corrected algorithm from Schneider, 1989]. The $\mathrm{B}$ component inclinations (Figures 6a-6f) are well grouped in five of the sites (Princeton, Titusville, Rutgers, Somerset, and Weston), with overall averages of the core mean inclinations $\left(\sim 42^{\circ}\right)$ and the precision parameter estimates $(k \sim 60)$ that are virtually indistinguishable from the predicted values based on the B component from the fully oriented outcrop sites of Witte and Kent [1991]. The B component inclinations in Martinsville, on the other hand, show a bimodal distribution characterized by a precision parameter of only 24 and a mean inclination of $51^{\circ}$ which may be due to contamination by a present-day magnetization component.

The A component distributions (Figures 6g-6i) are unimodal for Titusville and Nursery with mean inclinations consistent with acquisition in the present-day field. A bimodal distribution is, however, apparent for the A component inclinations from the Princeton drill core, suggesting interference between $A$ and $B$ component magnetizations as in Martinsville. Fortunately, there is a difference of only a few degrees between the expected declinations of the A and B component overprints, and thus interference between these secondary magnetizations will hardly affect the azimuthal orientation of the drill core samples.

There was greater variability in the isolation of the characteristic magnetizations. About one third of the gray shale samples with well-defined A components did not have an adequately defined higher unblocking temperature $\mathrm{Cm}$ component, largely due to the suspected presence of a dominant magnetic sulphide phase. Greater success was achieved in isolating a high unblocking temperature $\mathrm{Ch}$ component from the red sediments, with a rejection rate of only about $12 \%$ of those with well-defined overprint magnetizations. In summary, $54 \%$ of the 338 gray shale samples, $86 \%$ of the 2054 red sediment samples, or $82 \%$ of the 2392 total sediment samples provided acceptable overprint and characteristic magnetization directions (Table 1). All of the Orange Mountain Basalt samples gave well-defined characteristic component directions, although the absence of a consistent overprint does not allow separate azimuthal orientation.

The characteristic magnetizations in the sedimentary rocks, oriented according to the $A$ or $B$ overprint within each sample and corrected for bedding tilt, form a bipolar distribution in each drill core (Figure 7). The northerly and southerly groups of directions are interpreted to correspond to the normal and reversed polarity states, respectively, of the Late Triassic-earliest Jurassic paleomagnetic field. Sample directions more than $90^{\circ}$ from the northerly end of the best- fitting axis through each data set were inverted and standard Fisher statistics were applied to the common polarity data to calculate a mean direction for each core site (Table 3). The overall mean direction for the seven core sites is $D=3.4^{\circ}$ $I=13.2^{\circ} a 95=3.5^{\circ}$. This compares favorably with the reported characteristic magnetization directions obtained from the fully oriented outcrop sites in the Newark Basin that give an overall average of $D=4.3^{\circ} \quad I=11.0^{\circ} \quad a 95=3.4^{\circ}$ (based on the 53 class I sites from the studies of Witte and Kent [1989, 1990] and Witte et al. [1991]). The larger scatter in the characteristic component directions in the individual NBCP drill cores $(k \sim 15)$ compared to the outcrop studies $(k \sim 30$ and greater) can be largely attributed to a "noisy" compass (i.e., the contribution of dispersion from the overprint magnetization in the indirect method of core orientation), although the different levels of averaging (by samples in the drill cores and by sites in the outcrop studies) is a contributing factor.

The mean normal and reversed directions in each drill core deviate from being antipodal by about $10^{\circ}$ (range is $5.5^{\circ}$ in Weston to $15.7^{\circ}$ in Titusville), with the normal directions having a tendency to be steeper and somewhat better grouped than the reversed directions (Table 3). Although a systematic polarity asymmetry in the Late Triassic-earliest Jurassic geomagnetic field cannot be entirely excluded, the departure from antipodality in the normal and reversed polarity characteristic directions is more likely due to residual contaminations from overprint magnetizations even though every sample was subjected to complete progressive demagnetization to isolate the components. A residual contamination from either the A or B component, with steep to moderate inclination and northerly declination, would tend to make the northerly characteristic directions somewhat steeper and the southerly characteristic directions somewhat shallower and perhaps more scattered because of the larger angular differences. The small residual contaminations in any case do not influence interpretation of polarity; for determination of a paleomagnetic pole, their biasing effect is effectively minimized by averaging the normal and reversed directions in each drill core.

\section{Paleomagnetic Poles}

A paleomagnetic pole was calculated for each drill core from the mean characteristic directions after core orientation and correction for bedding tilt in each sample (Table 4). Despite the indirect method of core orientation, the paleomagnetic poles agree very well with the lower, middle and upper Newark paleopoles found in studies of outcrop [Witte and Kent, 1989, 1991; Witte et al., 1991] (Figure 8). The paleopoles from outcrop represent most of the Newark Basin section, i.e., the Carnian Stockton and Lockatong Formations (lower Newark), the Norian-"Rhaetian" Passaic Formation (middle Newark), and the Hettangian igneous extrusive zone (upper Newark), but they are not significantly different from each other. This suggested that apparent polar wander (APW) for North America was slow in the Late Triassicearliest Jurassic, a conclusion supported by other Late Triassic paleopoles from North America [Kent and Witte, 1993] and now by the paleopoles from the NBCP drill cores.

The paleopoles from the seven NBCP drill cores fall in an age-progressive swath of less than $10^{\circ}$ arc length, broadly similar to the character of APW suggested by the Newark 

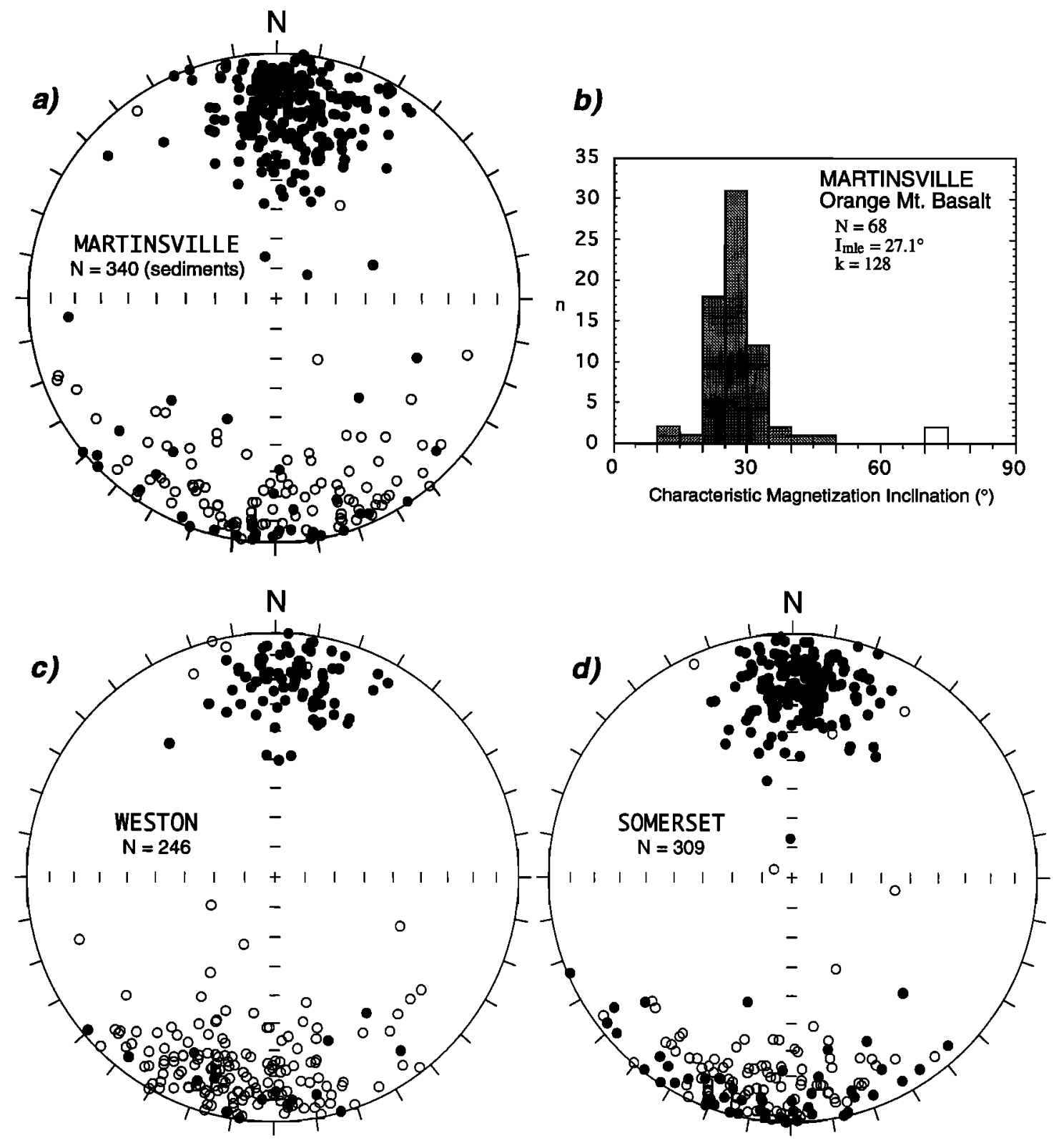

Figure 7. Directions of sample characteristic magnetizations in NBCP drill cores, plotted as open/solid symbols on upper/lower hemisphere of equal-area projections. The characteristic component direction in each sample was oriented in azimuth based on the overprint magnetization and corrected for bedding tilt based on dipmeter logs. The Orange Mountain Basalt in Martinsville drill core did not have useful overprints for azimuthal orientation; hence only a histogram of inclination data is shown in Figure $7 \mathrm{~b}$.

outcrop paleopoles (Figure 8). Paleopoles from the Titusville, Rutgers, Somerset, Weston, and Martinsville drill cores, which for the most part encompass the Passaic Formation of Norian-"Rhaetian" age, are separated by less than $5^{\circ}$; the paleopoles from the Nursery and Princeton drill cores that encompass the Lockatong and Stockton Formations of Carnian age extend the pole progression by another $5^{\circ}$. Even within the tight formal confidence limits resulting from the large number of samples included for each paleopole determination, paleopoles from stratigraphically adjacent drill cores are typically not significantly different (e.g., Titusville versus Rutgers), although paleopoles from more stratigraphically separated drill cores may be significantly different (e.g., Princeton versus Titusville).
The progression of paleopoles from Princeton to Martinsville may be interpreted as a high resolution APW path for North America featuring a drift episode in the Carnian (Princeton to Titusville) and a virtual standstill over the Norian-"Rhaetian" and the earliest Jurassic (Titusville to Martinsville). It is possible that some of the apparent polar shift in the Carnian could be an artifact of polarity bias (i.e., more than $2 / 3$ of the samples from the Nursery drill cores are reversed polarity with possibly biased, shallower directions), or perhaps in the case of Princeton drill core, where the number of normal and reversed polarity samples is subequal, sedimentary inclination error in the fluvial sediments of the Stockton Formation. These mechanisms, however, would not account for the stability in mean directions for the Titusville 

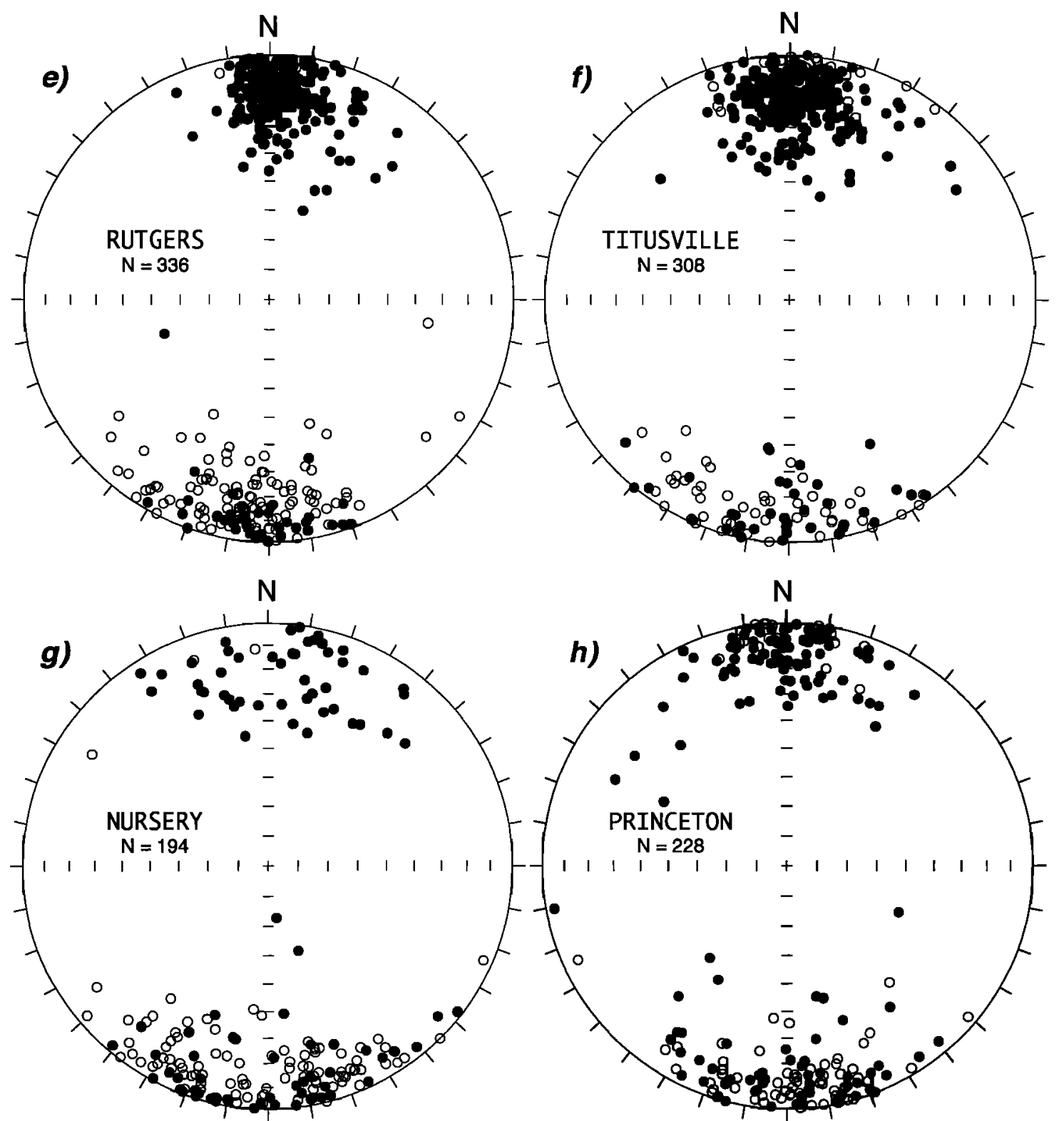

Figure 7. (continued)

to Martinsville drill cores, hence the Norian-"Rhaetian" standstill appears to be a real feature of APW for North America.

Some areas in the Newark Basin close to the border fault system are thought to have experienced local vertical axis tectonic rotations, clockwise and counterclockwise, on the basis of comparison of paleomagnetic data to reference directions from more interior parts of the basin [Van Fossen et al., 1986; Kodama et al., 1994]. Such local tectonic rotations are unlikely to have affected the NBCP drill core sites which are generally located in the main part of the basin and not close to major faults (Figure 1). A possible exception is the Martinsville site which is located near to the apparently clockwise rotated western limb of the Watchung syncline [Van Fossen et al., 1986]. Rotations may in any case be difficult to detect in the NBCP drill cores. This is because core orientation for most of the drill cores was based on the $B$ component which Kodama et al. [1994] suggest is rotated counterclockwise in the Sassamansville syncline area of the
Newark Basin. However, the overall consistency of the NBCP paleomagnetic poles, considering also that Titusville and Nursery in particular include a significant number of samples oriented with respect to the A component that realistically could not be rotated, suggests that local tectonic rotations are not important in the eastern and southeastern parts of the Newark Basin. This conclusion is supported by the agreement of the NBCP paleopoles with paleomagnetic results from other cratonic North America sites (Figure 8).

\section{Magnetostratigraphy}

The latitude of the virtual geomagnetic pole (VGP) combines declination and inclination in a diagnostic index of polarity [e.g., Lowrie and Lanci, 1994]. A VGP was calculated for each sample characteristic component direction after core orientation and correction for bedding tilt; the latitude of the sample VGP relative to the north paleomagnetic pole for each drill core was used for interpreting the polarity 
Table 3. Mean Directions and Fisher Statistics for Characteristic Magnetization in NBCP Drill Cores

\begin{tabular}{|c|c|c|c|c|c|}
\hline Site/Polarity & $n$ & $a 95$ & $k$ & $D$ & $I$ \\
\hline \multicolumn{6}{|l|}{ Martinsville* } \\
\hline Normal & 210 & $2.5^{\circ}$ & 15.9 & $4.3^{\circ}$ & $23.0^{\circ}$ \\
\hline Reversed & 130 & 5.3 & 6.5 & 182.7 & -9.6 \\
\hline Both & 340 & 2.4 & 9.7 & 3.7 & 18.2 \\
\hline \multicolumn{6}{|l|}{ Weston } \\
\hline Normal & 81 & 3.3 & 24.2 & 4.2 & 19.4 \\
\hline Reversed & 165 & 3.5 & 10.7 & 189.0 & -16.4 \\
\hline Both & 246 & 2.5 & 13.0 & 7.4 & 17.5 \\
\hline \multicolumn{6}{|l|}{ Somerset } \\
\hline Normal & 167 & 2.3 & 23.6 & 2.7 & 21.7 \\
\hline Reversed & 142 & 4.1 & 9.4 & 187.4 & -8.0 \\
\hline Both & 309 & 2.8 & 12.7 & 4.9 & 15.7 \\
\hline \multicolumn{6}{|l|}{ Rutgers } \\
\hline Normal & 194 & 1.9 & 29.0 & 3.6 & 16.7 \\
\hline Reversed & 142 & 3.5 & 12.1 & 185.4 & -10.6 \\
\hline Both & 336 & 3.1 & 17.9 & 4.3 & 14.2 \\
\hline \multicolumn{6}{|l|}{ Titusville } \\
\hline Normal & 222 & 2.1 & 20.5 & 2.1 & 17.2 \\
\hline Reversed & 86 & 4.8 & 10.9 & 185.2 & -1.8 \\
\hline Both & 308 & 3.2 & 14.9 & 2.9 & 13.0 \\
\hline \multicolumn{6}{|l|}{ Nursery } \\
\hline Normal & 50 & 6.4 & 10.9 & 2.7 & 19.7 \\
\hline Reversed & 120 & 4.2 & 8.8 & 181.5 & -5.0 \\
\hline Both & 194 & 2.6 & 8.8 & 1.8 & 8.8 \\
\hline \multicolumn{6}{|l|}{ Princeton } \\
\hline Normal & 109 & 3.4 & 17.2 & 359.0 & 11.5 \\
\hline Reversed & 119 & 4.3 & 9.9 & 179.7 & 1.0 \\
\hline Both & 228 & 2.6 & 11.7 & 359.3 & 5.1 \\
\hline
\end{tabular}

$n$ is number of samples, $a 95$ is radius of $95 \%$ confidence circle, is estimate of precision parameter, $D$ is declination and $I$ is inclination of mean directions in bedding coordinates.

*Excludes Orange Mountain Basalt.

stratigraphy. Relative VGP latitudes that are positive and ideally approach $+90^{\circ}$ (locus of the north paleopole) are interpreted as recording normal polarity, and those that are negative and ideally approach $-90^{\circ}$ (locus of the south paleopole) as recording reversed polarity. Two or more successive samples with the same polarity are used to delineate a magnetozone; boundaries between magnetozones are drawn at the stratigraphic midpoint between successive samples of opposite polarity.

Table 4. Paleomagnetic Pole Positions for Mean Characteristic Magnetizations in NBCP Drill Cores

\begin{tabular}{lcccccc}
\hline Drill Site & $\mathbf{n}$ & Latitude & Longitude & $d p$ & $d m$ & plat \\
\hline Martinsville* & 340 & $58.6^{\circ}$ & $98.4^{\circ}$ & $1.4^{\circ}$ & $2.7^{\circ}$ & $9.3^{\circ}$ \\
Weston & 246 & 58.0 & 91.5 & 1.4 & 2.7 & 8.9 \\
Somerset & 309 & 57.2 & 96.5 & 1.2 & 2.4 & 8.0 \\
Rutgers & 336 & 56.4 & 97.8 & 1.0 & 1.9 & 7.2 \\
Titusville & 308 & 56.2 & 99.9 & 1.1 & 2.2 & 6.6 \\
Nursery & 194 & 54.1 & 102.8 & 1.8 & 3.6 & 4.4 \\
Princeton & 228 & 52.3 & 105.3 & 1.6 & 3.1 & 2.6 \\
\hline
\end{tabular}

$n$ is number of samples, latitude and longitude are the north latitude and east longitude of the north paleomagnetic pole corresponding to the mean dual polarity directions in bedding coordinates (Table 3 ), $d p$ and $d m$ are the semiaxes of the $95 \%$ confidence oval, and plat is the paleolatitude of the drill site.

*Excludes Orange Mountain Basalt.

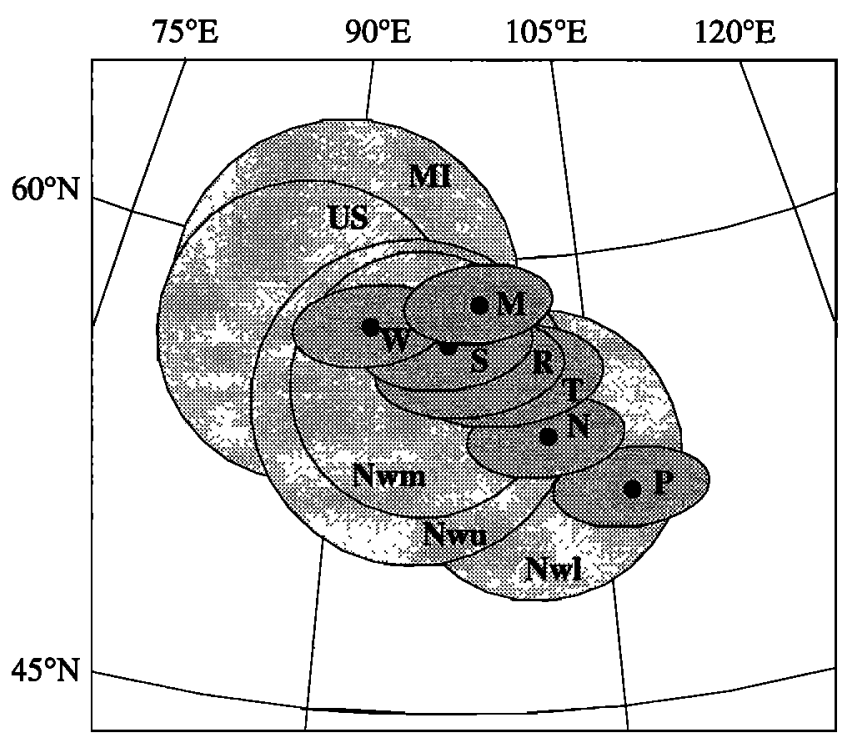

Figure 8. Paleopoles from NBCP drill cores (identified by first letter of drill site) compared to selected Late Triassic and earliest Jurassic paleopoles from stable North America tabulated and referenced by Kent and Witte [1993], all with 95\% confidence circles or ovals: Nwl, lower Newark; Nwm, middle Newark; Nwu, upper Newark; US, Upper Shale of Chinle in eastern New Mexico; MI, Manicouagan impact structure in Quebec. Paleopoles from the Colorado Plateau are not shown because of tectonic rotation.

For identification of magnetozones, the nomenclature for Newark Basin polarity zones based on outcrop from Witte et al. [1991] could be used, but this would require cumbersome modification to accommodate the many new magnetozones resolved in some intervals. We therefore chose to erect a new magnetostratigraphic nomenclature for the Newark Basin section based on the NBCP drill core results. To economize on the number of magnetozone identifiers, we take advantage of the iterative binary character of polarity stratigraphy by assigning integers (in ascending numerical order from the base of the recovered section) to successive pairs of predominantly normal and predominantly reversed polarity intervals. Each ordinal number is prefixed by the acronym for the source of the magnetostratigraphy (Newark Supergroup of the Newark Basin, but using " $E$ " rather than " $N$ " which can be confused with the conventional designation for normal polarity), and has a suffix for the dominant polarity ( $n$ is normal polarity, $r$ is reversed) of each constituent magnetozone. Polarity intervals that may occur within a magnetozone of higher rank can be labeled in a parallel manner, by assigning to successive pairs of the shorter polarity intervals subordinal integers (ascending upsection) which are then appended after a decimal point to the higher-order magnetozone designation and given a suffix indicating dominant polarity. The basic scheme is thus similar to that used for the Late Cretaceous and Cenozoic geomagnetic polarity sequence based on marine magnetic anomalies [Cande and Kent, 1992], except that the numbering sequence in the present system always proceeds from older to younger which is more convenient for stratigraphic description.

As described below, the lowermost part of the recovered section (Stockton Formation in the Princeton drill core) is a reversed polarity interval whose base is not defined. We 
designate this incomplete reversed polarity magnetozone as $\mathrm{E} 1 \mathrm{r}$, and define succeeding polarity magnetozone couplets (e.g., E2 = E2n and E2r, E3 = E3n and E3r, etc.) from the base of the overlying normal polarity interval. To balance the stratigraphic thickness of first rank magnetozones over the entire section and to avoid having short polarity intervals at their boundaries, we assigned several short polarity intervals to a lower rank (e.g., submagnetozones E13n.1n, E13n.1r, and E13n.2n in magnetozone E13n). Although the ranking of magnetozones is inevitably arbitrary, the hierarchical scheme should nevertheless be useful for description at different levels of resolution and to accommodate refinements. In all, we identify magnetozones E1r to E23n that include a total of 59 polarity intervals in the Newark Basin section recovered in the NBCP drill cores. The magnetostratigraphic data and lithologic logs for the seven drill cores are described below from the base of the cored section upward.

\section{Princeton}

About $250 \mathrm{~m}$ of the lower Lockatong Formation and $850 \mathrm{~m}$ of the underlying Stockton Formation were recovered at the Princeton site (Figure 9). After coring, the hole collapsed at about $720 \mathrm{~m}$ depth; open hole logs including hole deviation and dipmeter surveys could not be run below this level, and values of hole deviation and bedding attitude had to be extrapolated using logging results from above. The depth level of the hole collapse corresponds to a thin zone of fractured core with evidence of slickensides. Stratigraphic discontinuity across the suspected fault, however, may not be large because there is no polarity or marked facies change and the amount and degree of fault gouging are relatively small.

The magnetizations of the Princeton samples had diverse behavior. The buff to pinkish sandstones in the Stockton Formation were often weakly magnetized and had complicated demagnetization trajectories, whereas many of the more reddish siltstones and sandstone samples had univectorial magnetizations in which an overprint (the $A$ or $B$ component) necessary for orientation was not sufficiently well developed. The gray to black shales of the Lockatong Formation often had unstable magnetizations, especially in the higher unblocking temperature range where the characteristic component should reside. Thus only 228 of 405 samples provided results sufficiently reliable for magnetostratigraphic interpretation in the Princeton drill core.

The five outcrop sites in the Stockton Formation and three outcrop sites in the Lockatong Formation were of reversed polarity [Witte and Kent, 1989] and delineated Newark magnetozone a- in the previous nomenclature [Witte et al., 1991]. The more detailed magnetostratigraphy available from the Princeton drill core includes 11 normal polarity intervals, typically about $30 \mathrm{~m}$ in thickness, with nine normal magnetozones in the Stockton Formation and two in the lower Lockatong Formation. We designate the polarity intervals in the Princeton drill core as magnetozones E1r to E1lr. Magnetozone E7n includes the suspected fault at $\sim 720 \mathrm{~m}$ and may eventually need to be subdivided if there has been significant displacement; there is no similarity in the magnetostratigraphic pattern below and above the suspected fault, so the section is at least unlikely to be repeated. The base of the Lockatong Formation, identified by the first prominent lacustrine black shale unit of the Wilburtha Member, occurs near the base of magnetozone E10n which extends into the lowermost Scudders Falls Member. Another normal polarity magnetozone (E11n) includes most of the Princeton Member.

\section{Nursery}

The Nursery drill core recovered most of the Lockatong Formation and bottomed in the uppermost part of the Stockton Formation (Figure 10). The Lockatong Formation is dominated by gray to black shales, a deeper-water lacustrine facies that has not been known for providing good paleomagnetic results and consequently largely avoided in previous paleomagnetic studies of the Newark Basin. About $40 \%$ of the 324 samples taken in the Nursery drill core were rejected but the 194 acceptable samples provide a reasonably well-defined magnetostratigraphy.

The Nursery section is predominantly of reversed polarity with four normal polarity intervals. The contact between the Stockton and Lockatong Formations at about $930 \mathrm{~m}$ occurs within a normal polarity interval (magnetozone E10n) and the Princeton Member is predominantly of normal polarity (E11n). This is similar to the pattern seen in the stratigraphically overlapping part of the Princeton drill core and lends confidence to the correlation of magnetozones even though the recovery of a characteristic magnetization was often poor in the gray to black shale facies that characterizes this part of the Newark section. Most of the middle part of the Lockatong Formation has reversed polarity (magnetozones E11r and E12r), except for $30 \mathrm{~m}$ of normal polarity (E12n) from the upper Tohicken to the lower Prahls Island Members. A relatively thick $(\sim 120 \mathrm{~m})$ normal polarity interval (E13n) encompasses most of the Tumble Falls Member and the lower part of the Walls Island Member in the upper part of the Nursery drill core.

McLaughlin [1945, 1959] gave informal names to several distinctive red mudstone units that occur within the predominantly gray to black shales of the Lockatong Formation. These are given here for reference with respect polarity magnetozones and the revised member definitions of Olsen et al. [1995]. The First Thin Red in the upper part of the Skunk Hollow Member is within magnetozone E11r; the First Big Red in the upper part of the Tohicken Member is within magnetozone E12n; the Triple Red in the upper part of the Prahls Island Member and the Smith Corner Red in the upper part of the Smith Corner Member are within magnetozone E12r; and the Double Red in the upper part of the Tumble Falls Member is in magnetozone E13n. Magnetic polarity therefore is not dependent on lithology or the magnetic carrier, with either polarity state represented by hematite-bearing red shales and mudstones as well as magnetite-bearing gray to black shales.

\section{Titusville}

The Titusville drill core recovered the uppermost part of the Lockatong Formation and the lower part of the Passaic Formation (Figure 11). The predominantly red clastic facies of the Passaic Formation is generally associated with a more robust paleomagnetic signature in comparison to the predominantly gray and black shales of the Lockatong Formation (e.g., Nursery drill core). The magnetostratigraphy of the Titusville drill core is based on 308 samples, or $85 \%$ of the 363 samples measured. 


\section{PRINCETON}

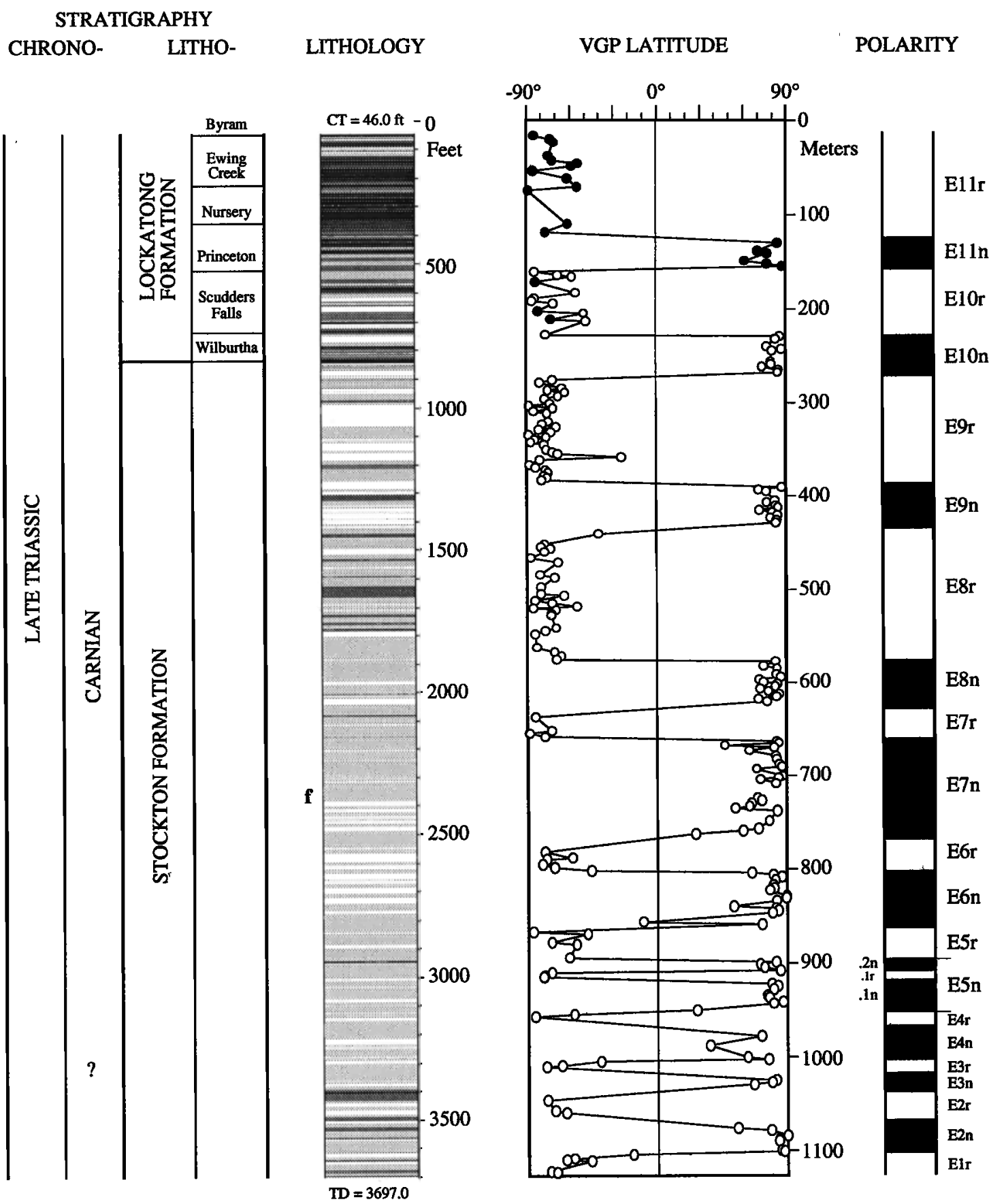

Figure 9. Physical stratigraphy, lithology, and magnetostratigraphy of the Princeton drill core. Lithology column shows dominant rock type according to legend in Figure 3, except for the Stockton Formation where the grain sizes in the fluvial facies are typically silty to sandy (rather than corresponding to mudstones) and buff rather than purple in color. A small fault is indicated by the letter "f" next to lithology column. CT is core top and TD is total depth. VGP latitudes were calculated from characteristic component directions after bedding tilt correction and plotted with respect to the north paleomagnetic pole (mean VGP); open and solid circles are for characteristic magnetizations carried by hematite and magnetite, respectively. Nomenclature for magnetozones (solid for normal polarity, open for reversed polarity, and half width for those based on only one sample) is described in the text.

The Titusville drill core just captures at its base a reversed polarity interval in the Tumble Falls Member that can be correlated to magnetozone E12r; the succeeding normal polarity interval correlates to magnetozone E13n, giving the same relation of magnetozones and lithologic members observed in the upper part of the Nursery drill core. The base of the Passaic Formation, where red clastic rocks became dominant over the gray and black shales of the Lockatong Formation [Olsen, 1980], is placed within the Walls Island Member at about $780 \mathrm{~m}$ in the Titusville drill core [Olsen et 
NURSERY

STRATIGRAPHY

CHRONO- LITHO-

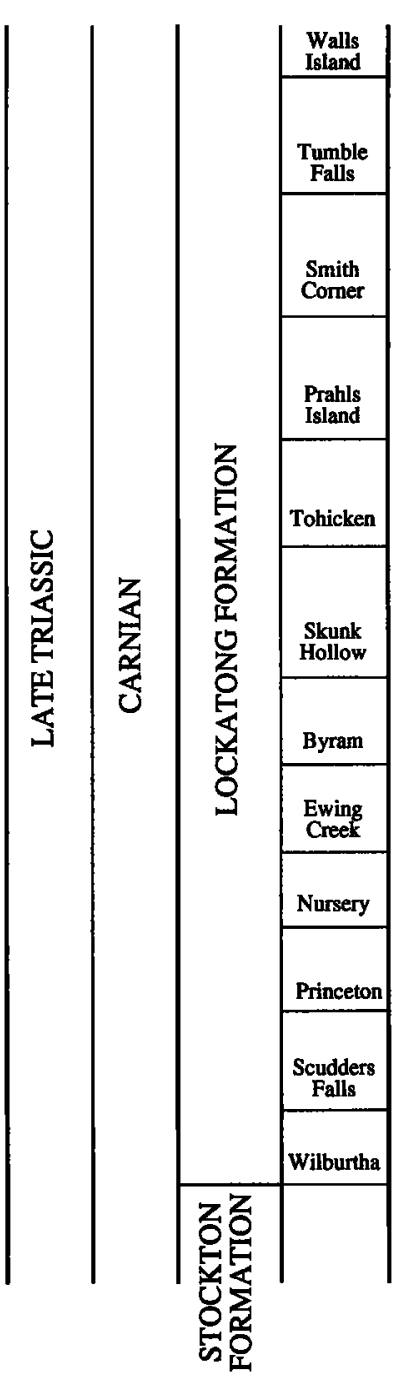

LITHOLOGY
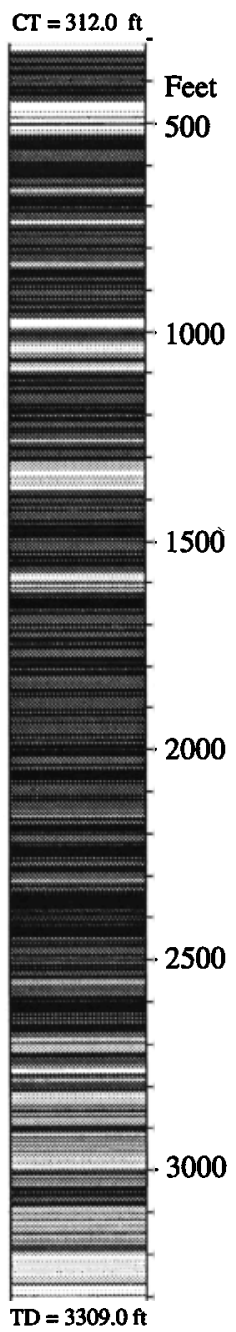

$\mathrm{TD}=3309.0 \mathrm{ft}$
VGP LATTITUDE

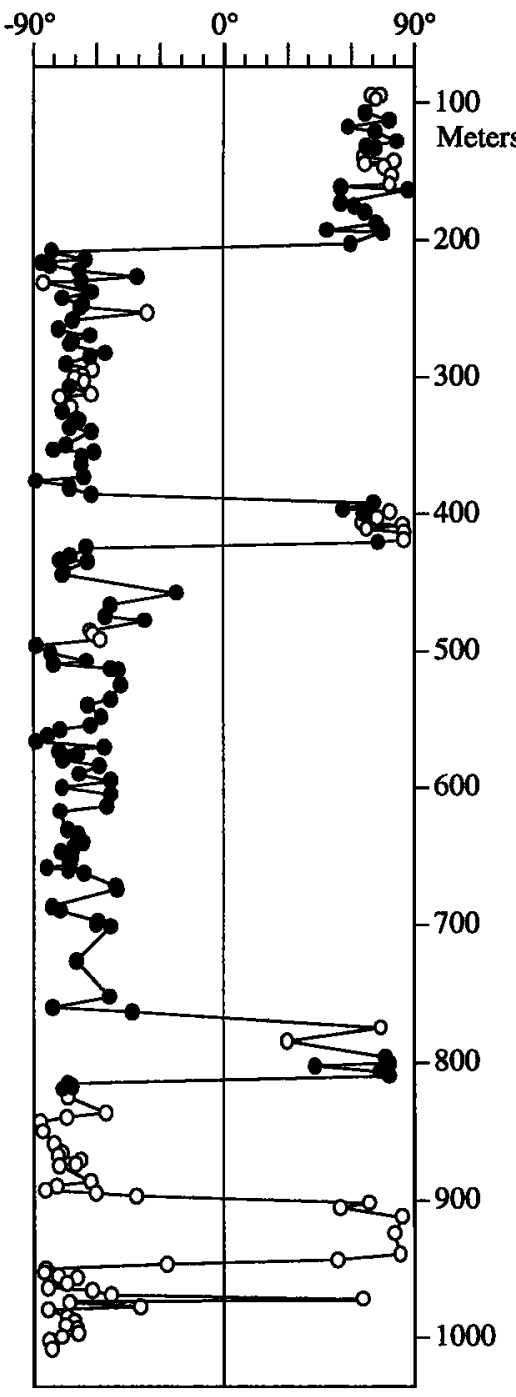

POLARITY

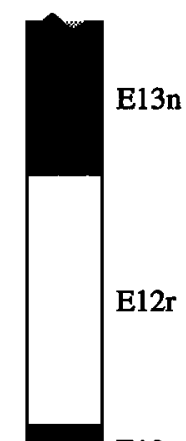

E12n

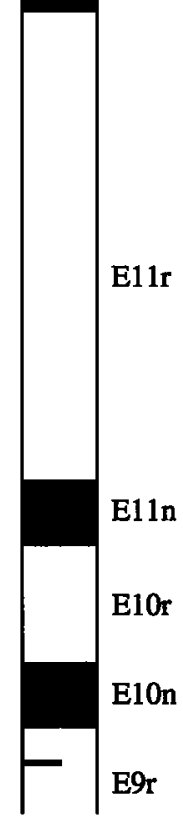

Figure 10. Physical stratigraphy, lithology, and magnetostratigraphy of the Nursery drill core. Conventions as in Figure 9.

al., 1995]. Magnetozone E13n is subdivided into a lower normal polarity interval (E13n.1n), a short reversed polarity interval (E13n.1r) near the contact between the Lockatong and Passaic Formations, and a $250 \mathrm{~m}$ thick normal polarity interval (E13n.2n) that extends to the upper part of the Warford Member. According to the outcrop study by Witte et al. [1991], a normal polarity magnetozone (referred to as $b+$ ) was also placed within what was broadly mapped as the lowermost Passaic Formation and most probably is correlative with magnetozone E13n.2n in the present study. The overlying $200 \mathrm{~m}$ of reversed polarity in the Titusville drill core (magnetozone E13r) and the nearly $300 \mathrm{~m}$ of normal polarity that extends from the uppermost part of the Graters Member to just below the base of the Perkasie Member (magnetozone E14n) clearly correlate to magnetozones c- and $\mathrm{d}+$, respectively, of Witte et al. [1991]. A reversed polarity interval (E14r) straddles the base of the Perkasie Member near the top of the Titusville drill core.

\section{Rutgers}

The Rutgers core hole was spudded about $42 \mathrm{~km}$ alongstrike from the Titusville site and recovered about $950 \mathrm{~m}$ of the mostly red middle Passaic Formation (Figure 12). The paleomagnetic record of the Rutgers drill core is particularly well defined, with only four samples rejected of the 340 measured.

The Rutgers drill core bottomed in a diabase body just below the base of member I; the contact aureole is only a few meters thick, suggesting that the sill-like intrusion is thin. The lower $230 \mathrm{~m}$ of section with normal polarity is identified as magnetozone E14n and is succeeded by reversed polarity 
TITUSVILLE
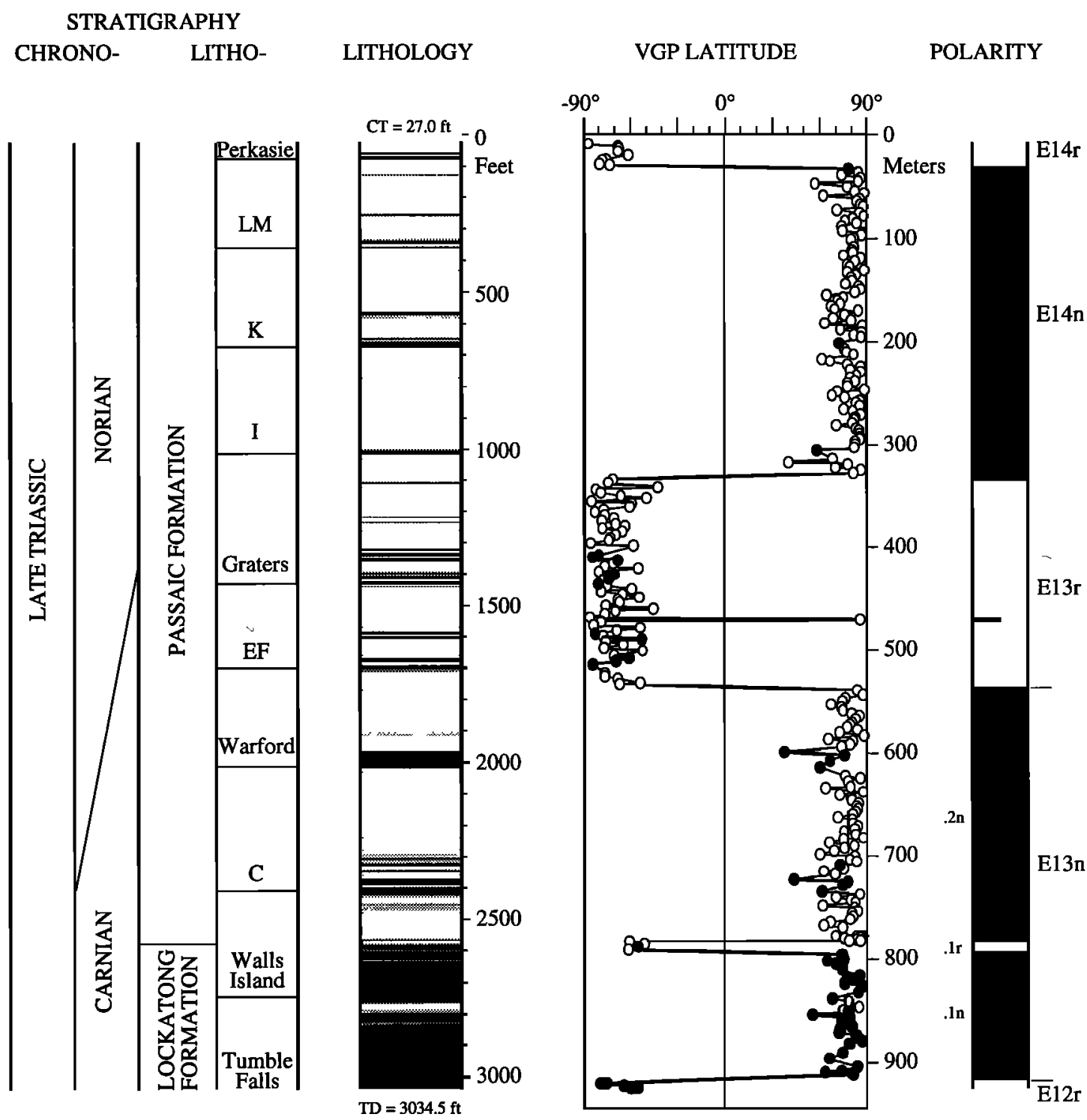

Figure 11. Physical stratigraphy, lithology, and magnetostratigraphy of the Titusville drill core. Conventions as in Figure 9.

(E14r) just below the base of the Perkasie Member, precisely the relationship observed in the Titusville drill core. The magnetostratigraphy of the Rutgers drill core also shows a remarkable confirmation of magnetozones in this part of the section which were defined by very few sites in outcrop [Witte et al., 1991]: magnetozone $\mathrm{E} 14 \mathrm{r}$ corresponds to $\mathrm{e}-$, magnetozone E15n to $f+$, and magnetozone E15r to $g$ - with the addition of a thin $(\sim 10 \mathrm{~m})$ normal polarity interval (E15r.1n). The upper $180 \mathrm{~m}$ of the Rutgers drill core, from near the base of the Kilmer Member to member $\mathrm{Y}$, has normal polarity associated with magnetozone E16n.

\section{Somerset}

The 920-m-deep Somerset drill core extends stratigraphic coverage of the Passaic Formation to the lower part of the Ukrainian Member (Figure 13). The paleomagnetic data for the predominantly red clastic facies are again excellent, with $94 \%$ of the 330 samples measured providing acceptable results.
The base of the Kilmer Member is closely associated with a reversed to normal polarity boundary (E15r/E16n) at Somerset, as observed at the Rutgers site. Magnetozones E16n and E17r are some of the thickest polarity intervals in the Newark section and broadly correspond to the thick magnetozones ( $h+$ and $\mathrm{i}-$ ) delineated in the outcrop study of the Newark Basin section [Witte et al., 1991]. The distinctive black shale unit at the base of the Ukrainian Member falls within the lower part of a relatively thin normal polarity interval identified as magnetozone E19n; this should correspond to magnetozone $\mathrm{j+}$ of Witte et al. [1991], although correlations in the E18n to E19n interval require modification, as described below, based on the mare detailed magnetostratigraphic information now available.

\section{Weston}

Weston, the last of the seven NBCP sites drilled, was targeted to fill a coring gap in the upper Passaic Formation 
RUTGERS

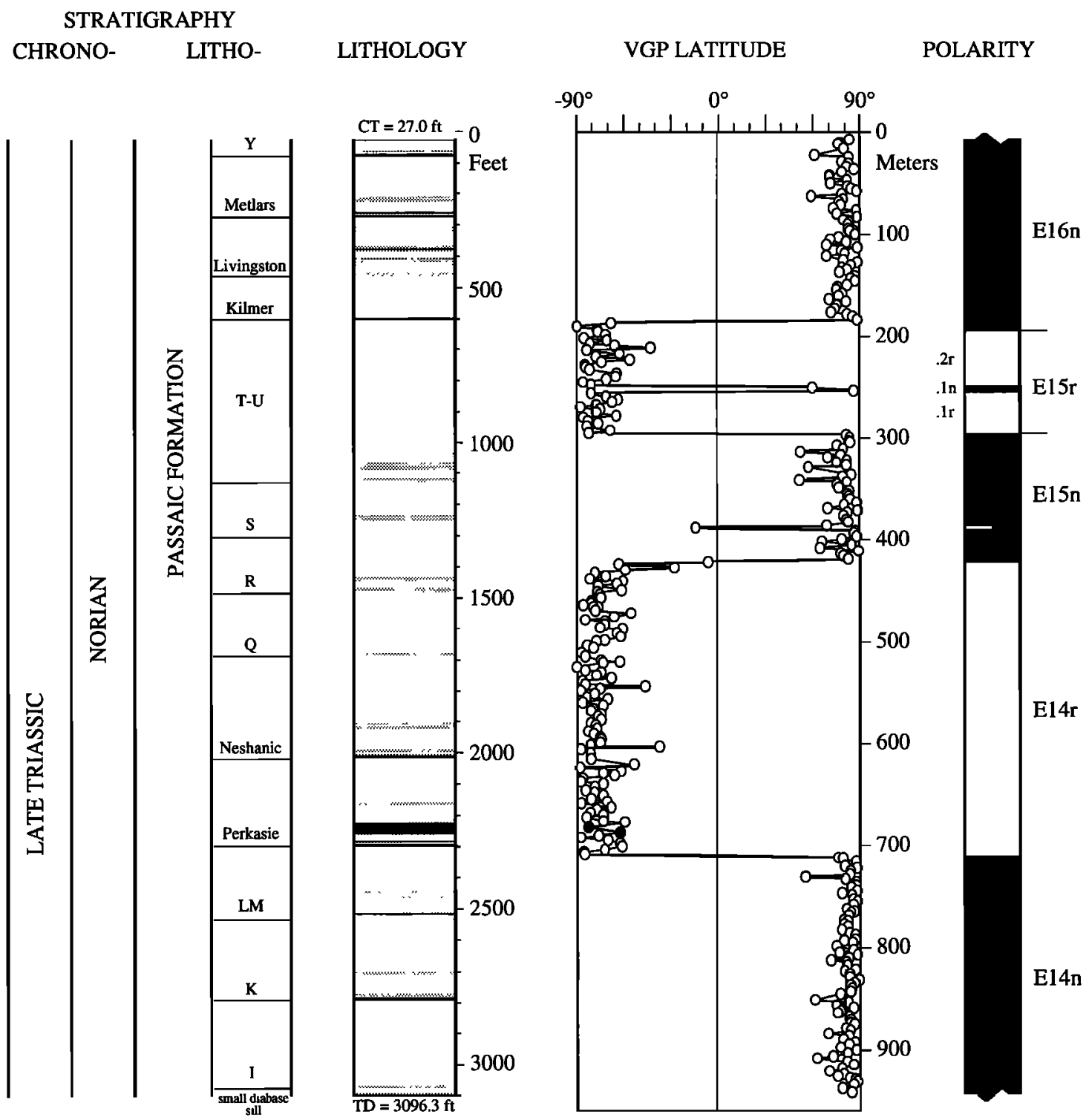

Figure 12. Physical stratigraphy, lithology, and magnetostratigraphy of the Rutgers drill core. Conventions as in Figure 9.

between the Somerset and the Martinsville drill cores. About $800 \mathrm{~m}$ of core of predominantly red clastic facies was recovered (Figure 14). Of the 260 samples measured, 95\% provided acceptable paleomagnetic results for magnetostratigraphy.

The polarity sequence in the lower part of the Weston drill core (magnetozones E17r to E19r) and its relationship to lithostratigraphic units (top of member DD to Ukrainian Member) are virtually the same as observed in the lower part of the Somerset drill core. Above magnetozone E19n $(=j+)$ that is associated with the Ukrainian Member, however, practically the entire upper part of the Passaic Formation had been tentatively assigned to reversed polarity (magnetozone k[Witte et al., 1991]). Outcrop is poor in this part of the Newark section, and the long reversed polarity interval was based on only four sampling sites. The detailed magnetostratigraphy now available from the Weston (and the Martinsville) drill core reveals a sequence of 15 normal and reversed polarity intervals in what had been considered an interval of only reversed polarity. Six of these polarity intervals (magnetozones E19r to E21n), varying in thickness

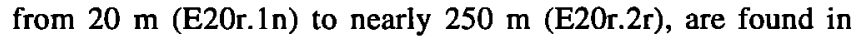
the Weston drill core.

\section{Martinsville}

The Martinsville core hole was the deepest of the NBCP sites and resulted in the recovery of virtually all of the Feltville Formation, the Orange Mountain Basalt, and the upper part of the Passaic Formation where it bottomed at a total depth of $1200 \mathrm{~m}$ (Figure 15). Core and information recovery was excellent, with 340 of the 370 sediment samples and all 70 basalt samples providing useful paleomagnetic data.

The Martinsville drill core extends the revised polarity record of $k$ - from magnetozones E20r and E21n, as already seen in the interval of stratigraphic overlap with Weston, to the top of magneozone E22r in the middle part of member SS. The upper $200 \mathrm{~m}$ of the Passaic Formation is mostly normal polarity (magnetozone E23n), punctuated by a thin reversed polarity interval (magnetozone E23n.1r) in the Exeter Member 


\section{SOMERSET}

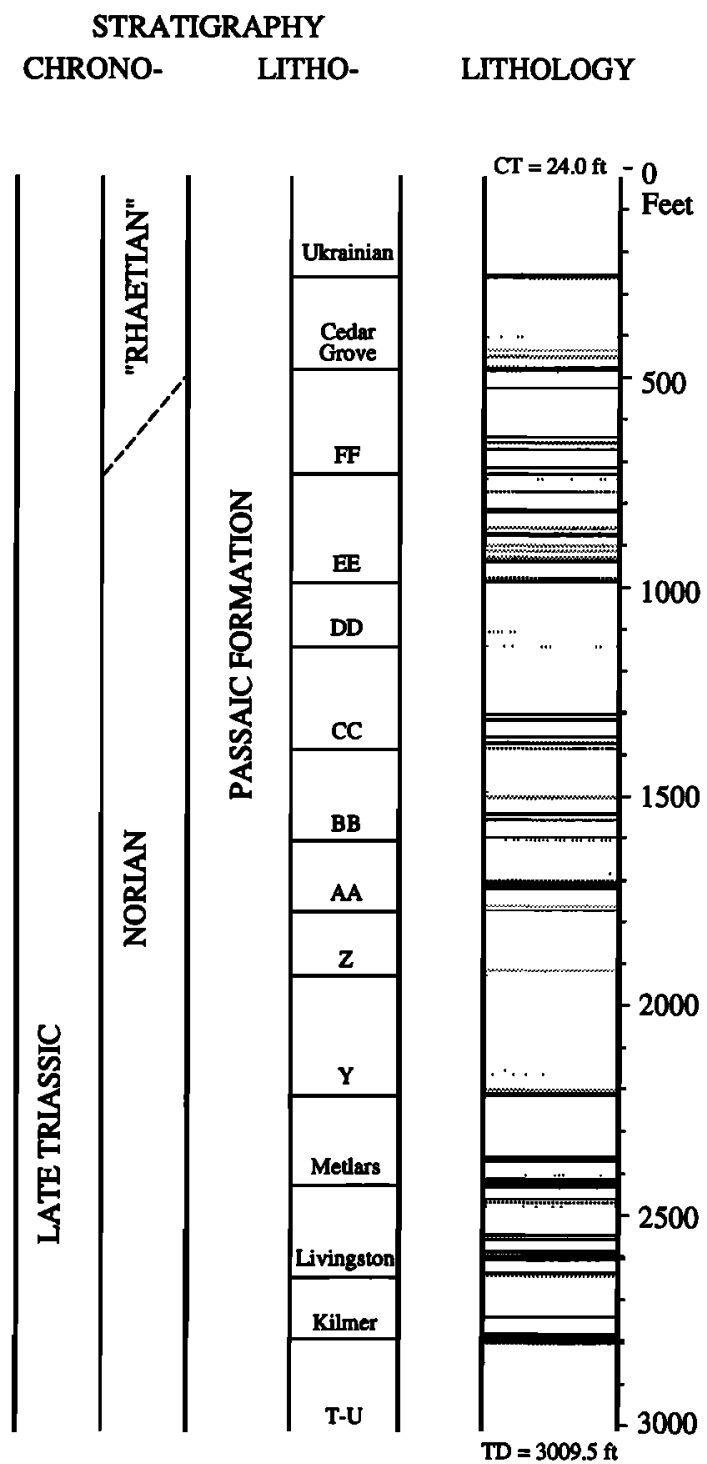

Figure 13. Physical stratigraphy, lithology, and magnetostratigraphy of the Somerset drill core. Conventions as in Figure 9.
VGP LATITUDE

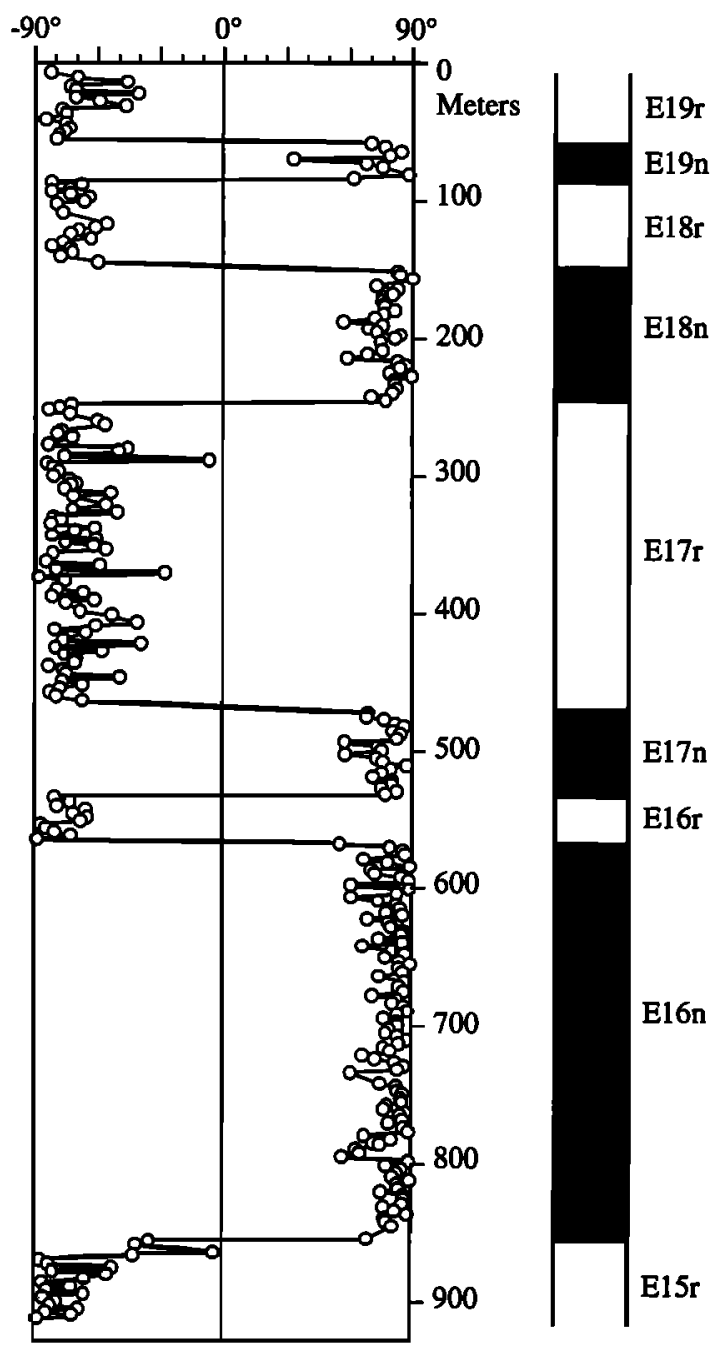

about $20 \mathrm{~m}$ below the contact with the Orange Mountain Basalt.

The NRM of the Orange Mountain Basalt typically had stable, univectorial magnetizations with no systematically resolvable overprints to allow azimuthal orientation (e.g., Figure 4g). Normal polarity of the Orange Mountain Basalt has in any case been well established from outcrop [e.g., Opdyke, 1961]. For the purpose of plotting the data from the Orange Mountain Basalt drill core samples, we assume that sample declinations for the characteristic component correspond to the mean declination established from fully oriented outcrop sites (mean of W1A and W1B of Prevot and McWilliams [1989]). VGP relative latitudes were then calculated for the adjusted characteristic component directions corrected for bedding tilt. Deviating directions are evident only in samples taken near the contacts between the lower/middle and the middle/upper flow units where alteration and/or physical disturbance is not unexpected. The Orange
Mountain Basalt and the overlying Feltville Formation extend the record of normal magnetozone E23n.2n from the very uppermost Passaic Formation.

\section{Lateral Continuity of Magnetozones}

The sedimentary cycles in the Lockatong and Feltville Formations are interpreted to represent basin-wide water depth variations in the Newark Basin lacustrine system in response to cyclical or Milankovitch climate change [Van Houten, 1964; Olsen, 1986; Olsen and Kent, 1995]. The distinctive McLaughlin cycles, in particular, have been successfully mapped as lithostratigraphic members over much of the Newark Basin [e.g., Olsen et al., 1995] and are believed to provide isochronous horizons for correlation. With regard to the chronostratigraphic significance of polarity magnetozones, the timimg of remanence acquisition in ancient sediments can be controversial, especially in the case of "red 


\section{WESTON}

STRATIGRAPHY

CHRONO- LITHO-

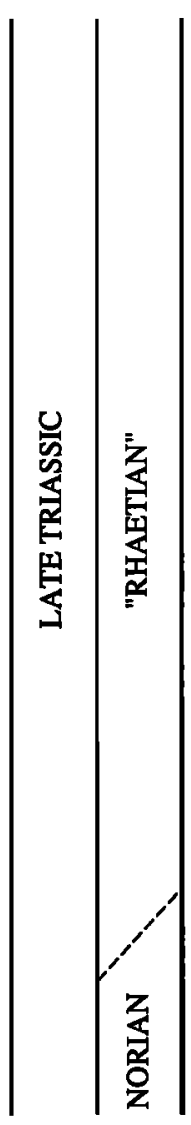

LITHOLOGY

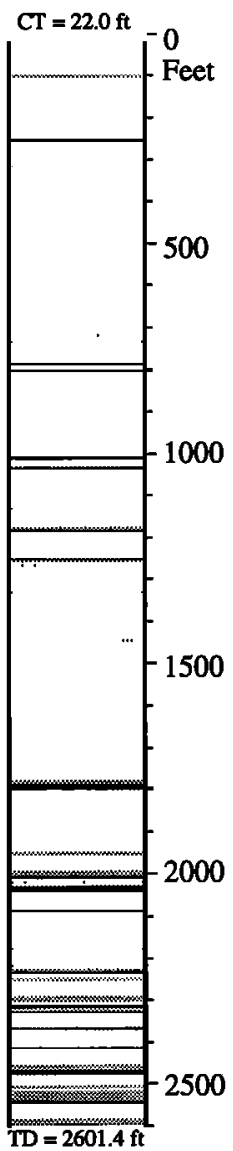

VGP LATITUDE

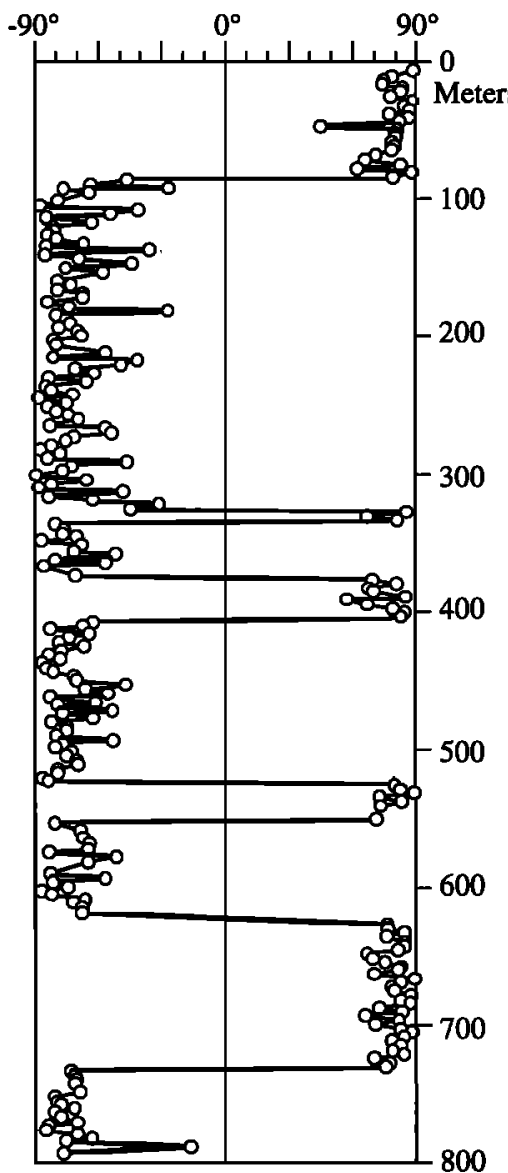

POLARITY

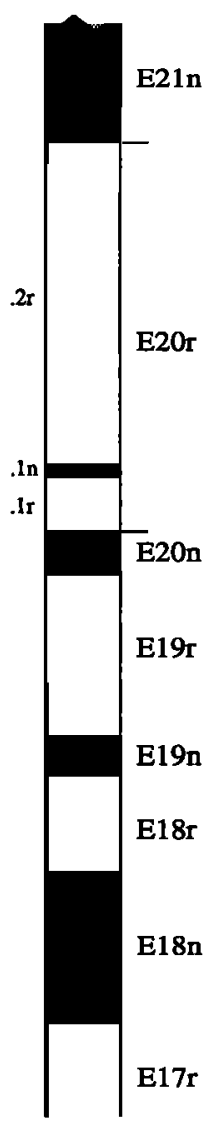

Figure 14. Physical stratigraphy, lithology, and magnetostratigraphy of the Weston drill core. Conventions as in Figure 9.

beds" in which several types and generations of hematite may be seen in petrographic observations [Larson and Walker, 1975; McIntosh et al., 1985]. However, an early acquisition of the characteristic magnetizations in the case of Newark red sediments in outcrop is already indicated by a positive fold test [Witte et al., 1991]. A more stringent but testable hypothesis is that the magnetozones delineated in the NBCP drill cores represent the polarity of the geomagnetic field close to the time of deposition, where the characteristic magnetizations were acquired as detrital or early diagenetic remanences. If the characteristic magnetizations are indeed original, the expectation is that the Newark lithostratigraphic members (McLaughlin cycles) and polarity magnetozones should occur in a consistent mutual stratigraphic relationship in different parts of the basin.

Lateral consistency between magnetozones and lithostratigraphic members can be tested in the intervals of stratigraphic overlap between the NBCP drill cores (Figure 16). Geographic distance between drill sites with stratigraphic overlap ranges from $4 \mathrm{~km}$ to $42 \mathrm{~km}$ and averages about $14 \mathrm{~km}$ for the six pairs. There are typically three or four member boundaries in common in the overlap intervals (e.g., Figures 16a-16d), with only one in Titusville-Nursery (Figure 16e) but six in Nursery-Princeton (Figure 16f), that were used for between-site correlation. Each overlap interval includes at least one magnetozone boundary (Figures 16a, 16c, 16d, and 16e), with four magnetozone boundaries in Weston-Somerset and in Nursery-Princeton (Figures $16 \mathrm{~b}$ and 16f). As already outlined in the descriptions of the individual drill core stratigraphies and highlighted below, the magnetozones and lithostratigraphic members in the lacustrine facies are in excellent mutual agreement in all six between-site comparisons.

The Titusville-Rutgers comparison (Figure 16d) provides an especially good test because these stratigraphically overlapping core sites are located the farthest apart $(\sim 42 \mathrm{~km})$. Targeted to join the Titusville and Rutgers sections was the Perkasie Member, the prominent black shale near its base making it one of the most distinctive and easily recognized members in the predominantly red Passaic Formation. In the Rutgers drill core, the base of the Perkasie Member occurs at $700.2 \mathrm{~m}$ (2297.3 feet), about $10.6 \mathrm{~m}$ above the E14n/E14r magnetozone boundary at $710.8 \mathrm{~m}(2332 \pm 4 \mathrm{feet})$. In the Titusville drill core, the base of the Perkasie Member is placed 
MARTINSVILLE

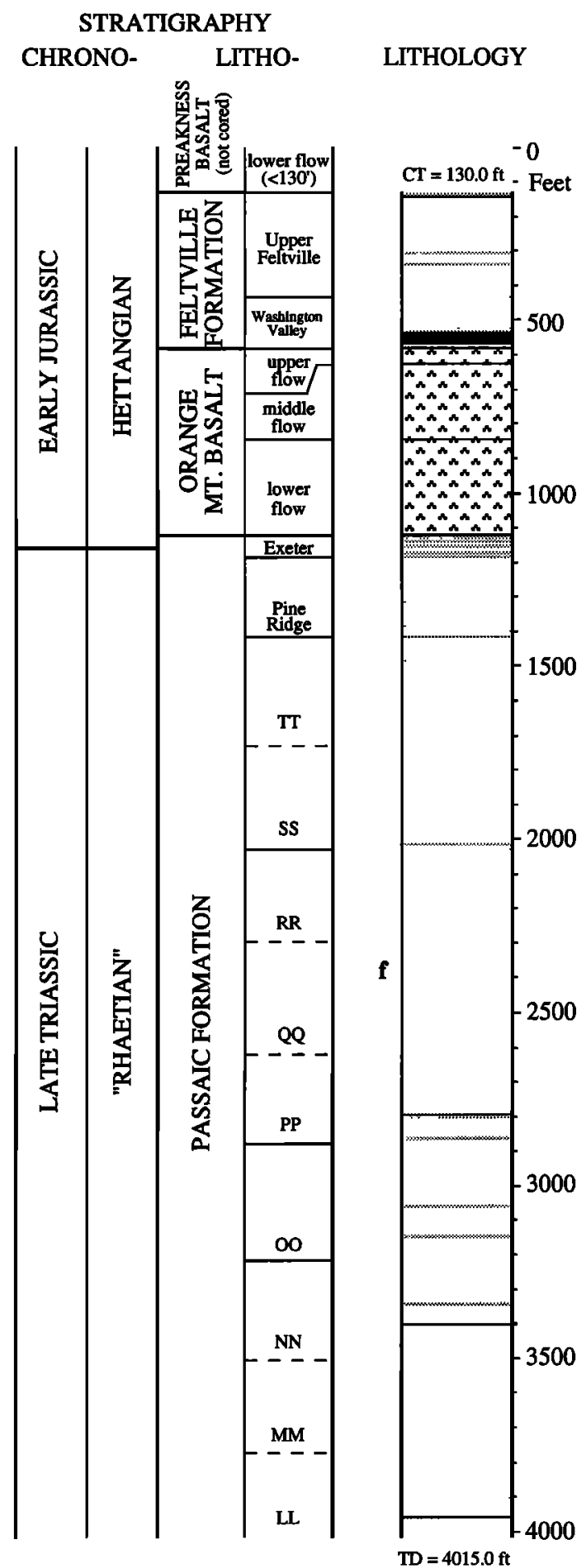

VGP LATITUDE

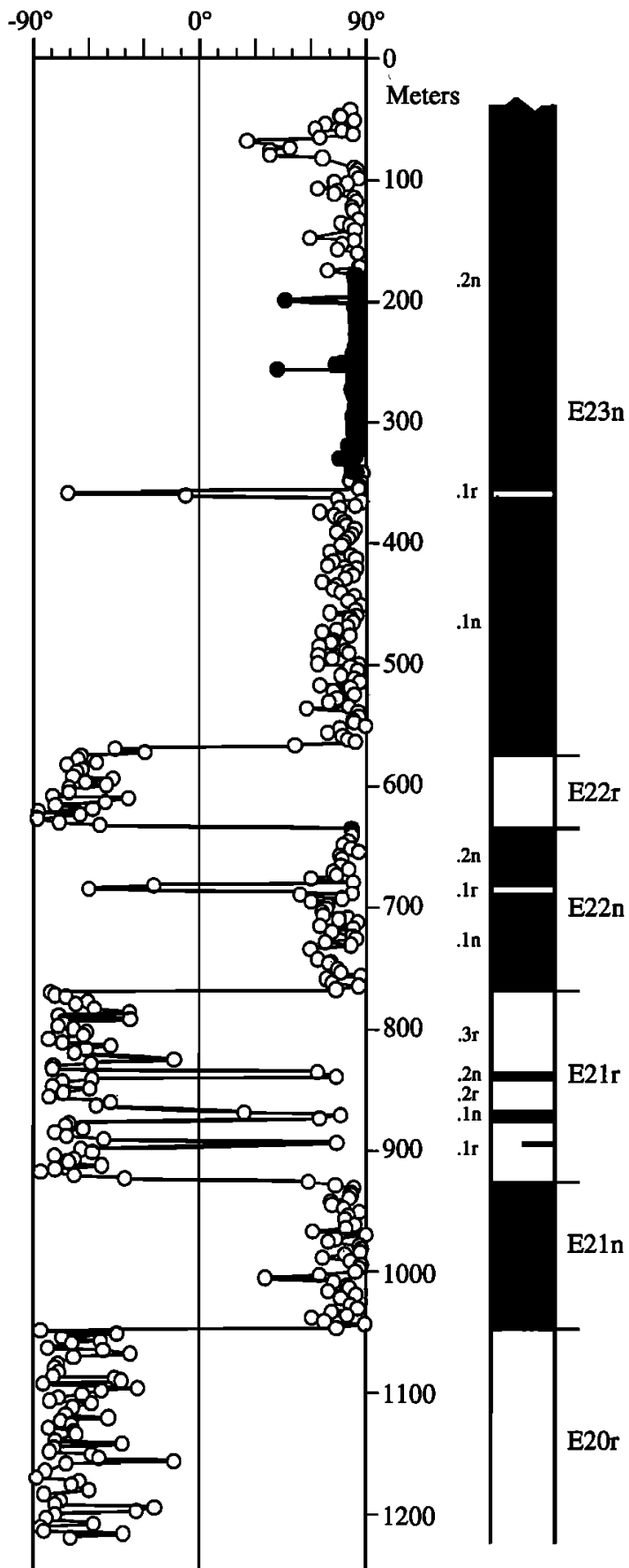

Figure 15. Physical stratigraphy, lithology, and magnetostratigraphy of the Martinsville drill core. Conventions as in Figure 9. Lithology column includes basalt.

at $23.5 \mathrm{~m}$ (77.1 feet), about $8.8 \mathrm{~m}$ above the $\mathrm{E} 14 \mathrm{n} / \mathrm{E} 14 \mathrm{r}$ magnetozone boundary at $32.3 \mathrm{~m}$ (106 \pm 7 feet), which is in excellent agreement with the stratigraphic relationships observed in the Rutgers drill core. The Raritan River outcrop section shows a similar although less well resolved relationship between magnetozones and the Perkasie Member [Witte et al., 1991; Olsen et al., 1995].
The Princeton and Nursery core sites are $18 \mathrm{~km}$ apart, the next largest separation, and each penetrated the transition between the fluvial Stockton Formation and the lacustrine Lockatong Formation (Figure 16f). This stratigraphic overlap between drill cores has the most lithostratigraphic members (six) as well as magnetozones (four) for comparison, which occur in the predominantly gray to black shales of the lower 
a) MARTINSVILLE

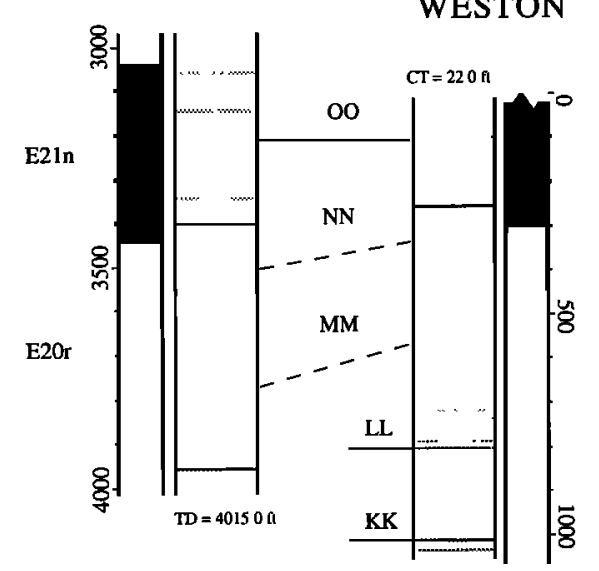

c) SOMERSET

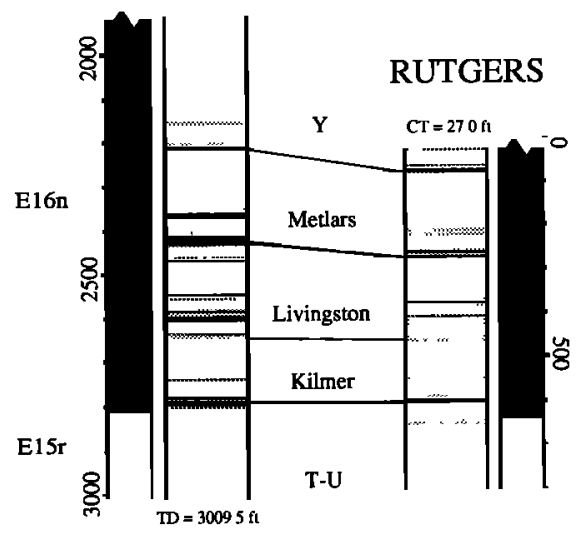

e)

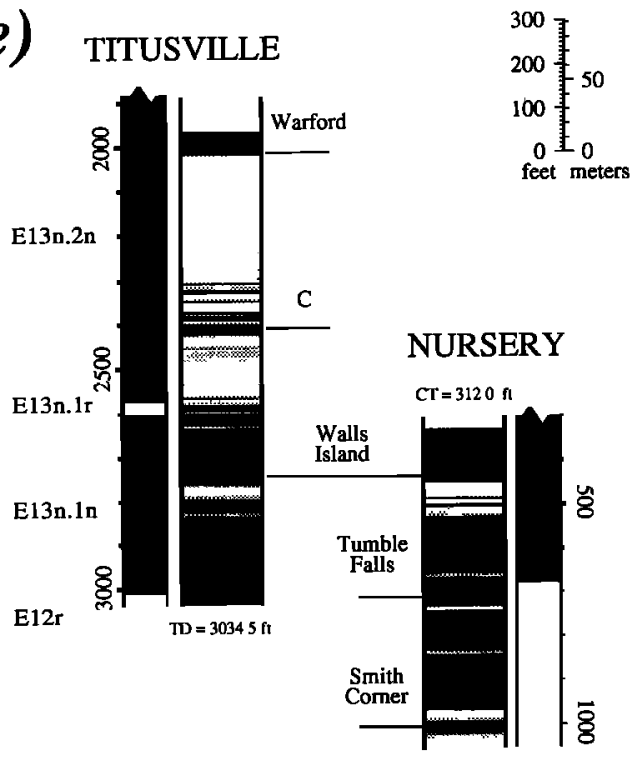

b)

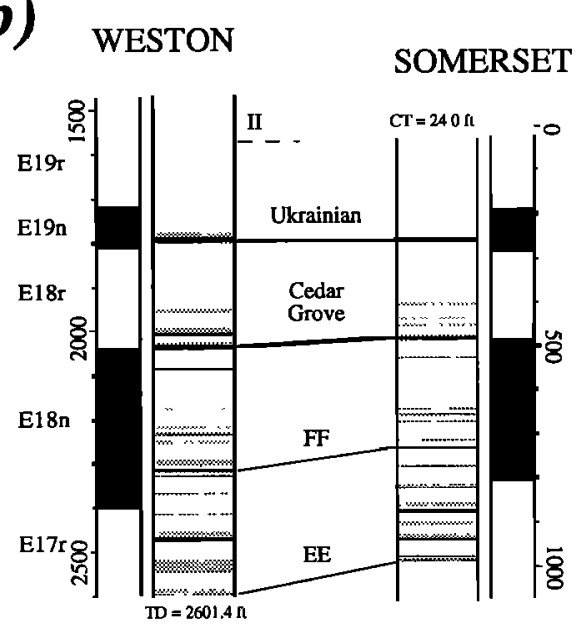

d) RUTGERS

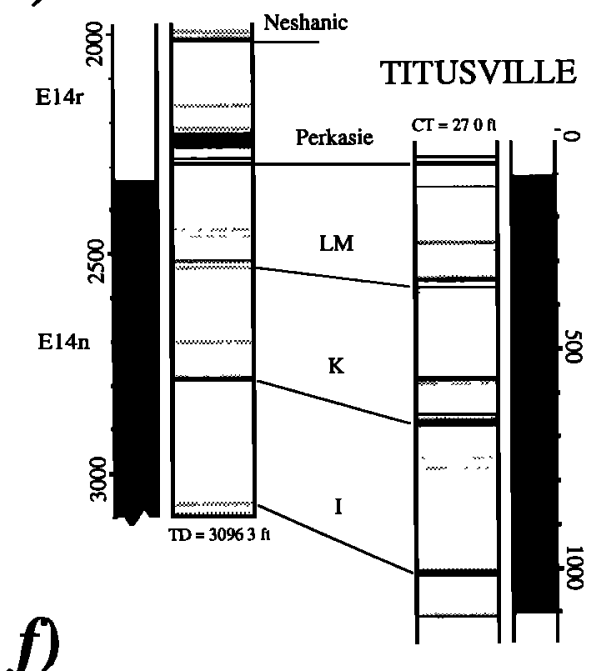

NURSERY

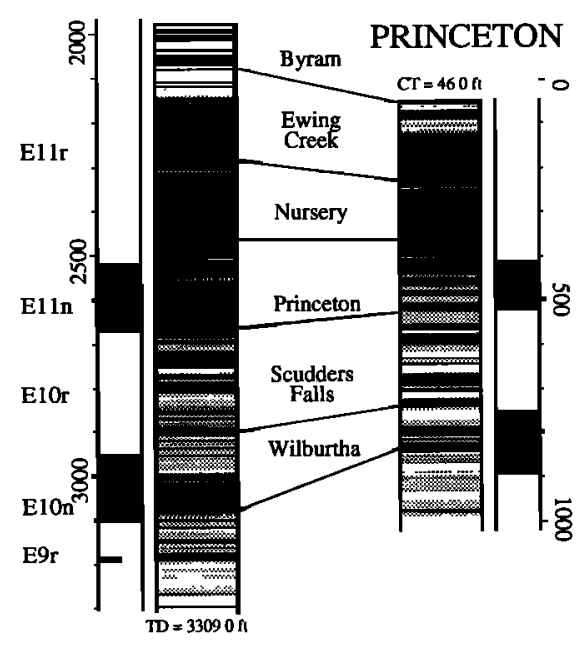

Figure 16. Comparison of lithology, lithostratigraphy, and magnetostratigraphy in the stratigraphically overlapping intervals of the NBCP drill cores. Conventions as described for Figure 9. Depths in each drill core are plotted at the same scale in feet (see separate scale for metric conversion). 
Lockatong Formation. Lithostratigraphic members of the lower Lockatong Formation are more closely spaced in Princeton than in Nursery, presumably reflecting lateral change in sedimentation rate, but the relationship to magnetozones is maintained. For example, the base of the Wilburtha Member (base of Lockatong Formation) is consistently in a normal polarity magnetozone (E10n) and the Princeton Member is associated with another relatively thin normal polarity magnetozone (E11n). There is only minimal stratigraphic overlap to test the lateral continuity of magnetozones in the Stockton Formation of fluvial facies, and the polarity sequence in this part of the section will need to be confirmed. However, the consistent correlations of lithostratigraphic members and magnetozones in the lacustrine facies between Princeton-Nursery, as well as between the other NBCP drill cores, support a very early acquisition of the characteristic magnetizations in both the magnetite-bearing gray to black shales as well as the hematite-bearing red shales, mudstones, and siltstones.

\section{Composite Magnetostratigraphic Section}

The between-site correlations allow the assembly of a lithostratigraphic and magnetostratigraphic composite section for the Newark Basin. Construction of the composite section is detailed by Olsen et al. [1995] and includes (1) integrating core logs from the adjacent wells 1 and 2 where needed (Weston, Somerset, Rutgers, Titusville, and Princeton sites) using at least one lithologically distinctive bed common to the two holes; (2) converting core depth to stratigraphic depth to account for hole deviation and bedding dip; (3) crosscorrelating the overlap intervals based on gamma logs and distinctive shale units and calculating linear regression parameters; (4) using the linear regressions to scale each drill core section with respect to the Rutgers drill core (chosen for normalization of stratigraphic thickness because it was centered geographically and stratigraphically within the basin and has about the average thickness of lithostratigraphic members); and (5) assembling a composite lithostratigraphic and magnetostratigraphic section using the downdip portion of each overlap record.

The cored stratigraphic section has a composite thickness of $4660 \mathrm{~m}$ normalized to the Rutgers drill core and a total of 59 magnetozones (Figure 17). The uppermost normal polarity interval (magnetozone E23n.2n) in the NBCP cores evidently extends through the overlying Preakness Basalt, Towaco Formation, Hook Mountain Basalt, and at least the lower part of the Boonton Formation on the basis of previous studies of samples from outcrop and the Army Corps of Engineers drill cores [McIntosh et al., 1985; Witte and Kent, 1990]. Even though the top is not defined, magnetozone E23n.2n at about $750 \mathrm{~m}$ (including the lavas) is already the thickest magnetozone in the Newark sequence. The remaining 58 polarity intervals have an average stratigraphic thickness (scaled to the Rutgers drill core) of about $70 \mathrm{~m}$, ranging from about $4 \mathrm{~m}$ (e.g., magnetozone E23n.1r) to over $300 \mathrm{~m}$ (e.g., magnetozone E11r).

The magnetostratigraphic synthesis of Witte et al. [1991] for the Newark Basin was based on measurements at 64 outcrop sites in sediments; 59 sites were judged to provide suitable data for magnetostratigraphic interpretation and delineated 12 polarity intervals (Figure 17). A total of 59 magnetozones are delineated with the much higher and more uniform density of sampling of the NBCP drill cores than was possible in the outcrop studies; nevertheless, polarity intervals b+, c-, d+, e-, and $f+$ remain intact as originally defined, and only a single new polarity submagnetozone has been discovered in each of polarity intervals $\mathrm{g}-, \mathrm{h}+, \mathrm{i}-$, and $\mathrm{l}+$. The two long reversed polarity intervals, one that was thought to encompass the Stockton and Lockatong Formations (a-) and the other about the upper third of the Passaic Formation (k-), were originally defined by few outcrop sites and require the most revision on the basis of the detailed magnetostratigraphy available from the NBCP drill cores. Newark a- now includes 13 normal and 14 reversed polarity intervals (magnetozones E1r to E13n.1r in the revised nomenclature) and $\mathrm{k}$ - now includes seven normal and eight reversed polarity intervals (magnetozones E19r to E22r).

There is, however, an apparent inconsistency in the correlation of polarity interval $j+$ with $E 19 n$, in which the latter at $\sim \mathbf{3 0} \mathrm{m}$ is much thinner in the Somerset and Weston drill cores than the several hundred meters estimated for $j+$ from the outcrop sites (Figure 17). Only the base of a normal polarity magnetozone was exposed and sampled at the type locality of the Ukrainian Member; the other outcrop sites with normal polarity and included as $\mathrm{j}+$ were taken from the Jacksonwald area of the Newark Basin [Witte et al., 1991]. The correlation of the distinctive Ukrainian Member from the type section to the nearby Somerset and Weston drill cores is unambiguous, and all these records show that the base of the member lies in the lower part of an interval of normal polarity (i.e., magnetozone E19n). Our recent mapping in the Jacksonwald area, however, has found two black shale units that lie stratigraphically above the black shale that had been thought to be the base of the Ukrainian Member. It now appears that the original black shale unit may instead correspond to the base of member FF, and the two newly discovered black shale units are thus associated with the Cedar Grove and Ukrainian Members. This suggests that the thick normal polarity magnetozone originally found in the Jacksonwald section should correlate to $i .2+$ (= magnetozone E18n) rather than to $j+$ (= magnetozone E19n). New paleomagnetic results from the Jacksonwald area support this revised interpretation (Figure 18) which also demonstrates the

Figure 17. (opposite) Newark Basin composite section where cumulative stratigraphic thickness is scaled to the Rutgers drill core based on correlation of the stratigraphically overlapping intervals between the drill cores. Conventions as described for Figure 9. Section includes stratigraphic results from Army Corps of Engineers (ACE) cores described by Fedosh and Smoot [1988]. The magnetic polarity sequence from the NBCP drill cores is compared to that based on outcrop sites and ACE cores from Witte et al. [1991]. Various symbols to the right of polarity column for outcrop sites represent magnetostratigraphic sampling levels from various localities in the Newark Basin that were used to construct the composite; arrow suggests a revised stratigraphic correlation of sampling site (half solid triangle) at Ukrainian Member type locality (see text). 
NEWARK BASIN SECTION: DEPTH
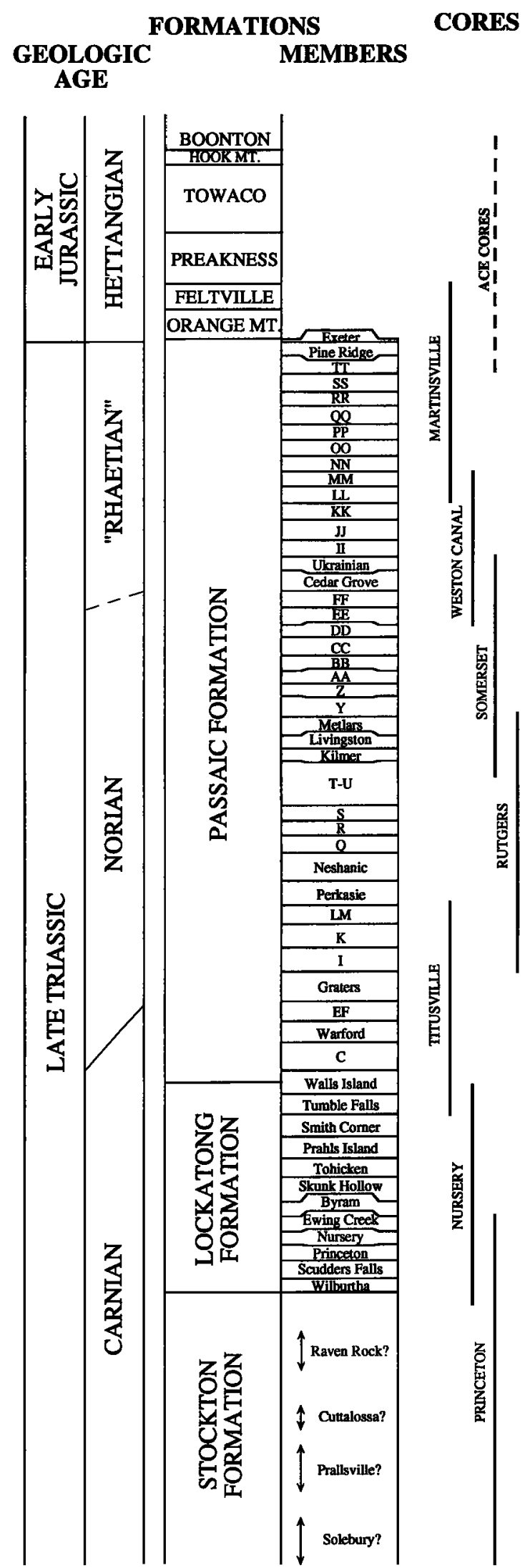

LITHOLOGY

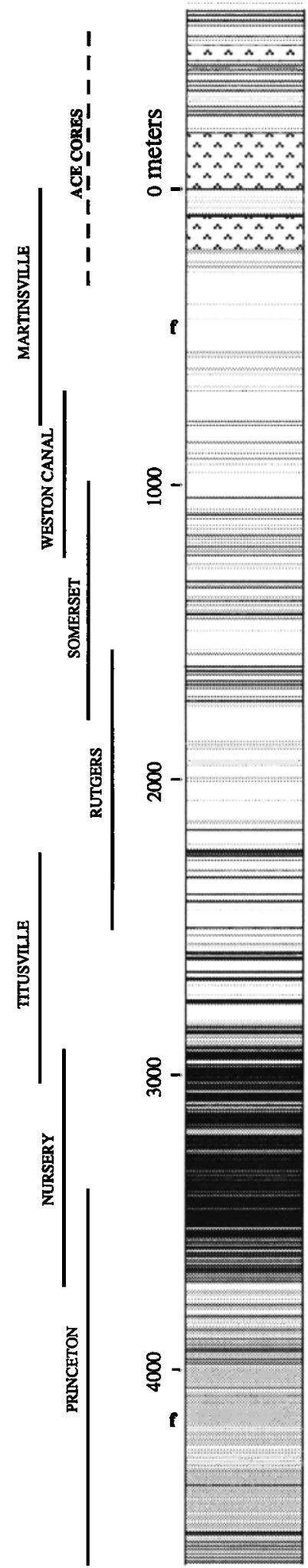

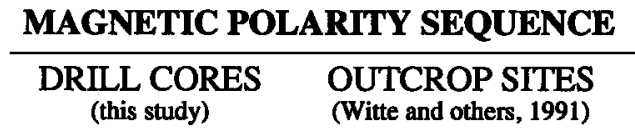

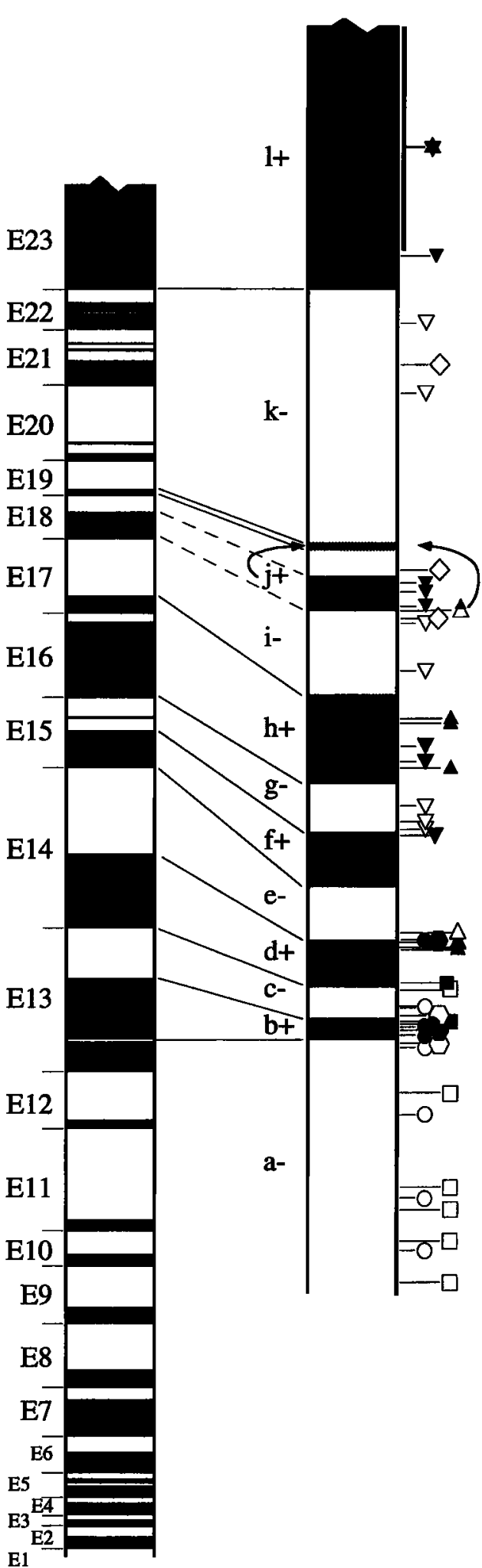


(4)

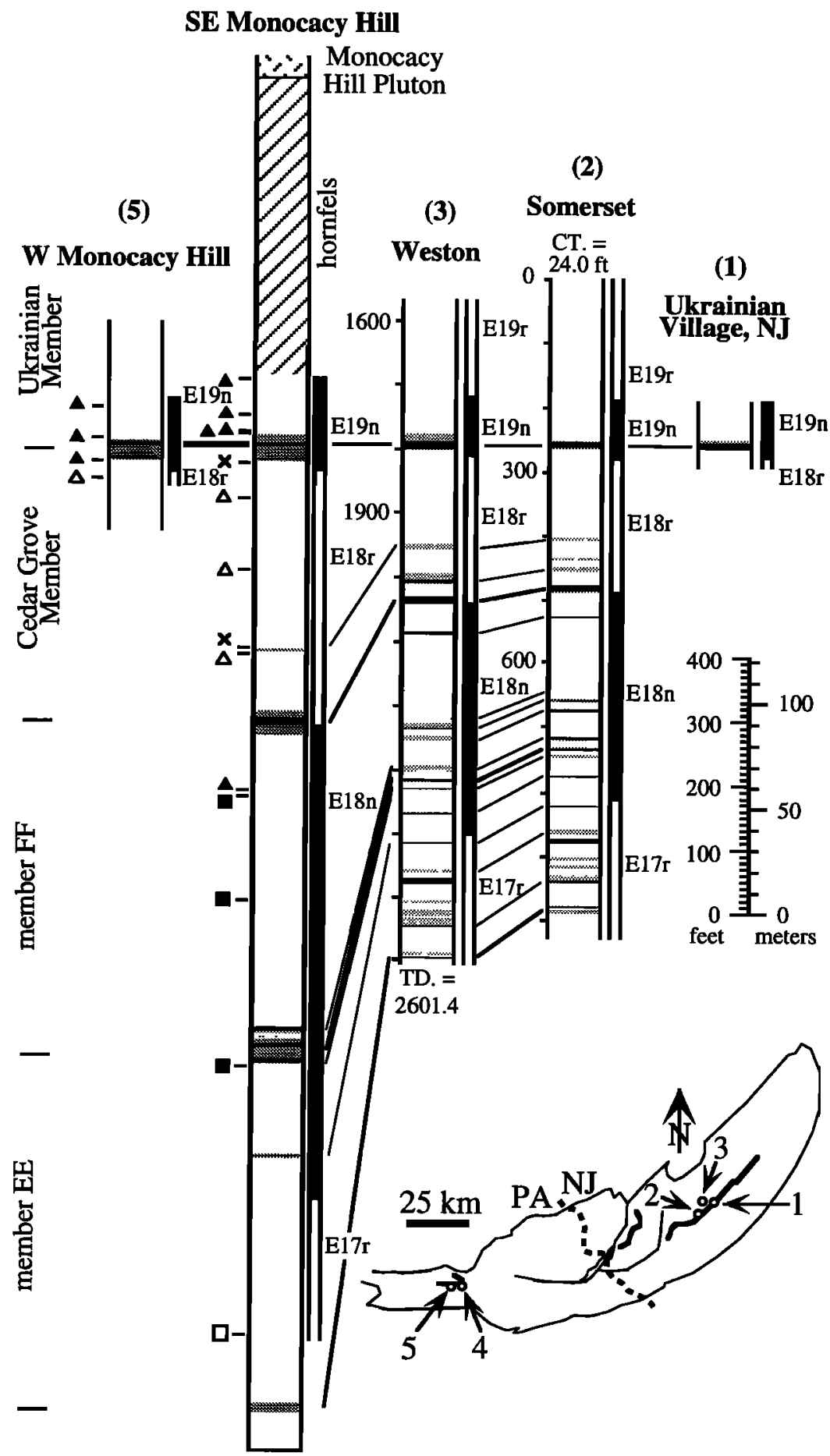

Figure 18. Comparison of magnetostratigraphic and lithostratigraphic data from the upper Passaic Formation in the stratigraphic interval of the Ukrainian Member. Polarity and lithology columns for the type locality of the Ukrainian Member (1) are from Witte et al. [1991], and for the Somerset and Weston drill cores ( 2 and 3 ) from this paper. Data for the Jacksonwald outcrop sections (4 and 5) include paleomagnetic results from Witte et al. [1991] (squares) and from hand samples reported here (triangles; $x$ 's for indeterminate polarity); solid or open symbols represent normal or reversed polarity. Inset shows location of sections in the Newark Basin with heavy lines representing outcrop trace of Ukrainian Member. 
lateral continuity of key lithostratigraphic members and polarity intervals on a scale of more than $100 \mathrm{~km}$ in the Newark Basin.

\section{Late Triassic-Earliest Jurassic Geomagnetic Polarity Timescale}

To convert the Newark Basin magnetostratigraphic sequence into a geomagnetic polarity timescale, an age model is developed on the basis of biostratigraphy, radiometric dates, and cycle stratigraphy. The Triassic/Jurassic boundary is constrained by palynology to lie within a thin $(\sim 1 \mathrm{~m})$ interval within the Exeter Member, correlated to be about $20 \mathrm{~m}$ below the contact with the Orange Mountain Basalt in the NBCP section [Olsen et al., 1990; Fowell and Olsen, 1993; Fowell et al., 1994; Olsen et al., 1995]. There is no physical evidence of an unconformity associated with the Triassic/Jurrassic boundary interval. Concordant radiometric

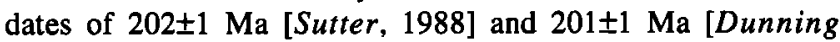
and Hodych, 1990] were obtained from the Palisade sill, which is linked physically and geochemically to the basaltic lavas (most likely the Preakness Basalt) of the Newark igneous extrusive zone [Kodama, 1983; Ratcliffe, 1988]. On the basis of cyclostratigraphy of the sediments of Jurassic age that are interbedded with the lavas, where, for example, the Van Houten cycles are generally much thicker than in the Triassic age Passaic Formation, the Newark extrusive zone is believed to represent a relatively short $(\sim 1 \mathrm{~m} . \mathrm{y}$.$) igneous and$ depositional episode [Fedosh and Smoot, 1988; Olsen and Fedosh, 1988]. This suggests that the radiometric dates can be used to provide an estimate of $\sim 202 \mathrm{Ma}$ for the palynological Triassic/Jurassic boundary as recorded in the uppermost Passaic Formation. U-Pb zircon dates of $202 \pm 1 \mathrm{Ma}$ from the North Mountain Basalt [Hodych and Dunning, 1992], which lies a few meters above the palynological Triassic/Jurassic boundary in the Fundy basin, Nova Scotia [Fowell and Olsen, 1993], support the close synchroneity of igneous activity in the Newark rift basins and a Triassic/Jurassic boundary age of $\sim 202 \mathrm{Ma}$.

Although a wide range of age estimates for the Triassic/Jurassic boundary appears among even recently published geologic timescales, and criteria for recognition of the Norian/"Rhaetain" boundary are very uncertain [e.g., Van Veen, 1995], most of these timescales give consistent estimates of around 15-17 m.y. for the duration of the Norian"Rhaetian", i.e., between the Carnian/Norian and Triassic/Jurassic boundaries (e.g., $215 \mathrm{Ma}$ to $200 \mathrm{Ma}$ [Webb, 1981]; $220 \mathrm{Ma}$ to $204 \mathrm{Ma}$ [Odin and Létolle, 1982]; $225 \mathrm{Ma}$ to $208 \mathrm{Ma}$ [Palmer, 1983]; 223.4 Ma to $208 \mathrm{Ma}$ [Harland et al., 1990], revised from $225 \mathrm{Ma}$ to $213 \mathrm{Ma}$ of Harland et al. [1982]; and 220.7 Ma to 205.7 Ma [Gradstein et al., 1994]). There are 38 to 40 lithologic members or McLaughlin cycles in this 15-m.y. interval (using the most recent timescale of Gradstein et al. [1994]) of the Passaic Formation. The resulting average duration of about $400 \mathrm{kyr}$ for the McLaughlin cycles is close to a main Milankovitch periodicity of climate change, calculated as $413 \mathrm{kyr}$ from celestial mechanical terms of the cycle of eccentricity of Earth's orbit [Berger, 1977; Berger et al., 1992]. The same periodicity is found in spectral analyses of the full, broadband Newark climatic record [Olsen, 1986; Olsen and Kent, 1995].

Assuming that the McLaughlin cycles represent the 413kyr celestial mechanical cycle, the Lockatong Formation with

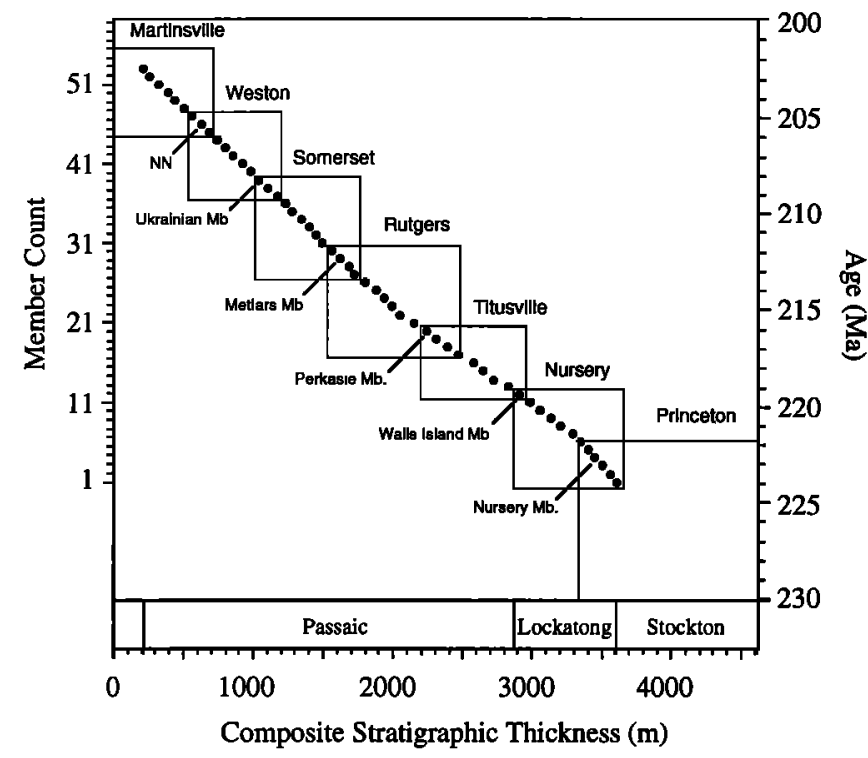

Figure 19. Lithostratigraphic members numbered sequentially from the base of the Lockatong Formation to the top of the Passaic Formation as a function of stratigraphic thickness of the composite section (normalized to the Rutgers drill core). Note that T-U is assumed to be two separate members even though not readily differentiated lithologically in the Rutgers drill core. Conversion to time is based on an age for the Triassic/Jurassic boundary (within member number 53, Exeter Member) of $202 \mathrm{Ma}$ and assuming that each member represents a 413-kyr McLaughlin cycle. Boxes show the stratigraphic range encompassed within each drill core; key members in common between drill cores are labeled for reference.

11 to 12 members spans about 4.75 m.y. and the Passaic Formation with 41 to 42 members spans about 17 m.y. (Figure 19). Long term sedimentation rates (in Rutgers normalized depth units) in the lacustrine Lockatong and Passaic Formations vary from about $140 \mathrm{~m} / \mathrm{m} . \mathrm{y}$. in the lower Lockatong and in the middle to upper Passaic Formations, to about $200 \mathrm{~m} / \mathrm{m}$.y. in the upper Lockatong and lower Passaic Formations, with an overall average of about $160 \mathrm{~m} / \mathrm{m}$.y. The magnetostratigraphic sampling interval of $\sim 3 \mathrm{~m}$ corresponds to a nominal temporal resolution of 15 to $20 \mathrm{kyr}$, approximately at the level of the Van Houten cycles. Cycles have not been identified in the Stockton Formation, and with the absence of biostratigraphic control the timescale in this fluvial facies is poorly constrained. If the sedimentation rate in the Stockton Formation was similar to that of the lower Lockatong Formation in the Princeton drill core, the cored interval of the Stockton Formation might span about 6.8 m.y. Allowing approximately $1 \mathrm{~m} . \mathrm{y}$. for the igneous extrusive zone, the entire Newark section may thus represent nearly 30 m.y. of the Late Triassic and earliest Jurassic.

The sequence of Newark magnetozones was transformed into a geomagnetic polarity timescale using the chronological control outlined above (Figure 20). Polarity reversal ages in the Lockatong and Passaic Formations were interpolated from the position of magnetozone boundaries within the members (McLaughlin cycles) which were each assumed to be $413 \mathrm{kyr}$ in duration. In the Stockton Formation, where McLaughlin cycles are not apparent, polarity reversal ages were estimated assuming a constant sedimentation rate of $140 \mathrm{~m} / \mathrm{m} . \mathrm{y}$. The 
NEWARK BASIN SECTION: AGE

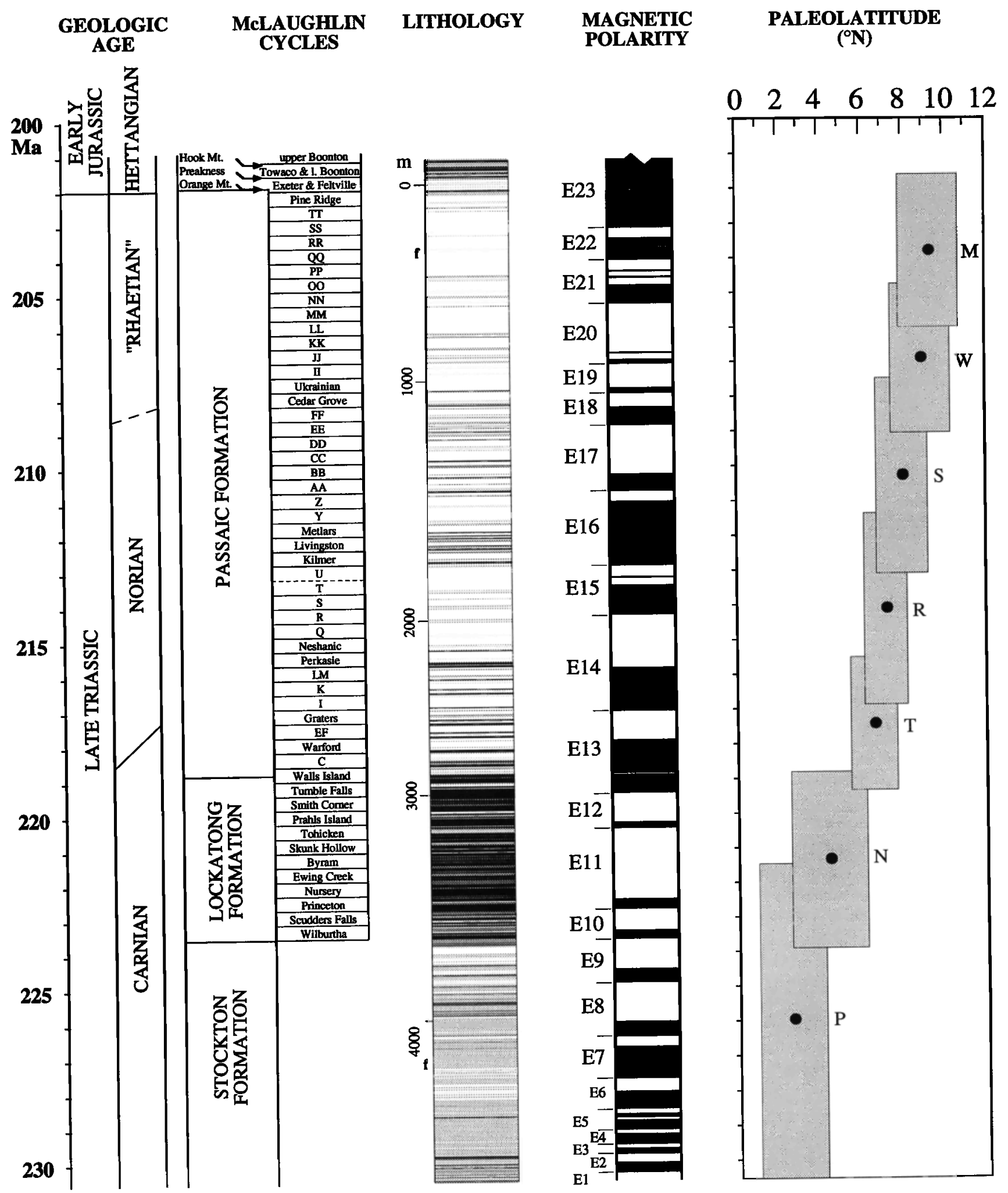

Figure 20. Newark Basin composite section transformed into a chronostratigraphy, using an age of $202 \mathrm{Ma}$ for the Triassic/Jurassic boundary and assuming that the lithologic members (McLaughlin cycles) each represent $413 \mathrm{kyr}$ and that the Stockton Formation has a sedimentation rate of $140 \mathrm{~m} / \mathrm{m} . \mathrm{y}$. Conventions as described for Figure 9. Note that T-U is assumed to be two separate members even though not readily differentiated lithologically in the Rutgers drill core. Magnetic polarity column includes results for the earliest Jurassic not covered by the NBCP drill cores from McIntosh et al. [1985], Witte and Kent [1990], and Witte et al. [1991]. Mean paleolatitudes (solid circles) and associated 95\% confidence intervals (width of shaded boxes) are based on the mean characteristic magnetizations for the NBCP drill cores whose stratigraphic intervals are indicated by the heights of the shaded boxes. 
limited range of sedimentation rates in the Late Triassic part of the section means that there is not much change in the relative spacing of polarity intervals when transformed into magnetochrons. There is, however, a large change in the earliest Jurassic where the very thick normal polarity magnetozone E23n.2n that encompasses the lavas and interbedded sediments of the Newark extrusive zone may be only about $1 \mathrm{~m} . \mathrm{y}$. long.

Average geomagnetic reversal frequency for the entire section is about $2 / \mathrm{m}$.y., or an average polarity interval duration of approximately $500 \mathrm{kyr}$. For the better chronicled post-Stockton Formation sequence, average polarity interval duration is $560 \mathrm{kyr}$ and reversal frequency is about $1.8 / \mathrm{m} . \mathrm{y}$. Polarity intervals range from a number as short as $0.03 \mathrm{~m} . \mathrm{y}$. (magnetosubchrons E15r.1n and E22n.1r) to a few as long as about 2 m.y. (magnetochrons E11r and E16n), with an overall resemblance to an exponential distribution of polarity lengths. There is no significant polarity bias, with $46 \%$ (54\%) of the total section duration represented by normal (reversed) polarity.

In addition to a detailed polarity sequence, paleomagnetic data from the NBCP drill cores provide improved constraints on paleogeography. The systematic age progression of paleopoles from the NBCP drill cores has already been shown to agree well with other North American reference poles. An important element of the apparent polar wander can be portrayed as the change of the locality's paleolatitude with time, a representation that is not strongly dependent on uncertainties in azimuthal core orientation or any local vertical-axis rotations. Over the $\sim 30 \mathrm{~m}$.y. interval of the Late Triassic-earliest Jurassic represented by the Newark Basin section, eastern North America evidently drifted northward by about $7^{\circ}$ (Figure 20). The NBCP drill cores suggest a shift in paleolatitude from about $2.5^{\circ}$ to $6.5^{\circ}$ north over the Carnian (Princeton to Nursery to Titusville) and from about $6.5^{\circ}$ to $9.5^{\circ}$ north over the ensuing Norian-"Rhaetian" and earliest Jurassic (Titusville to Martinsville). Although the paleolatitudinal record may be affected in detail by biases in the characteristic magnetization inclinations (hence inferred paleolatitudes), especially for the Carnian Stockton and Lockatong Formations, a tropical setting for the Newark Basin and an overall slow rate of northward motion over the Late Triassic and earliest Jurassic are robust interpretations of the data.

\section{Correlation With Other Magnetostratigraphies}

The magnetic polarity sequence from the NBCP drill cores provides a consistent framework for temporal correlation within the Newark Basin and we would also propose, constitutes a reference section for a Late Triassic-earliest Jurassic geomagnetic polarity timescale. The inferred ages of the palynologically defined stage boundaries are generally a few million years younger but within the quoted uncertainties of age estimates in the most recent Mesozoic timescale of Gradstein et al. [1994], which might, however, suggest that the lower part of the Stockton Formation could extend into the Ladinian. Here we attempt to correlate with the Newark the few magnetostratigraphic sections of Late Triassic age that are available from other regions. These are a representative magnetostratigraphic section from the nonmarine Chinle Group of the southwestern United States [Reeve and Helsley, 1972; Lucas et al., 1993], and important work that has become available from Tethyan limestones of Carnian and
Norian age [Gallet et al., 1992, 1993, 1994] which provide an opportunity to attempt correlation with marine biostratigraphies. Molina-Garza et al. [1991] and Witte et al. [1991] reviewed other magnetostratigraphies for the Late Triassic, mainly from nonmarine sections, and these will not be discussed further here. These included earlier work on the Newark Basin [McIntosh et al., 1985] and preliminary work on the Fundy basin [Symons et al., 1989] from eastern North America, a short drill core section from the Fleming Fjord Formation of east Greenland [Reeve et al., 1974], several isolated sections of the Chinle Group [Molina-Garza et al., 1991], as well as a compilation of results from Russia by Khramov [1987] for which few details are available.

The nonmarine Chinle Group of the southwestern United States has a rich vertebrate fauna [e.g., Lucas and Hunt, 1993] and has been the subject of ongoing magnetostratigraphic investigation since the work of Reeve and Helsley [1972], one of the earliest magnetostratigraphic studies of Upper Triassic rocks in North America. The polarity sequence at Luciano Mesa reported by Reeve and Helsley [1972] is still one of the longest published magnetostratigraphies available from the Chinle and was recently used as the basis of a discussion of correlations with the Newark polarity sequence from outcrop [Lucas et al., 1993; Witte et al., 1993]. According to Lucas et al. [1993], regional correlations and biostratigraphic constraints suggest that the $145-\mathrm{m}$ Chinle section sampled by Reeve and Helsley [1972] at Luciano Mesa encompasses the early-middle Norian Bull Canyon Formation and the late Norian or "Rhaetian" Redonda Formation. A tentative correlation that broadly satisfies these constraints of the Luciano Mesa magnetostratigraphy as portrayed by Lucas et al. [1993] with the new Newark polarity sequence is shown in Figure 21. The normal polarity interval in the lower part of the Bull Canyon Formation may correlate with Newark magnetochron E17n, the pair of normal polarity intervals in the lower part of the Redonda Formation with magnetochrons $E 18 n$ and $E 19 n$, and the relatively thick normal polarity interval at the top of the Chinle section may possibly correlate with magnetochron E21n. The Luciano Mesa section would thus encompass about $6 \mathrm{~m} . \mathrm{y}$., and the fluvial sediments accumulated at an average rate of $-25 \mathrm{~m} / \mathrm{m}$.y. The Luciano Mesa section sampled by Reeve and Helsley is apparently underlain by $400-500 \mathrm{~m}$ of additional Upper Triassic strata [Lucas et al., 1993] which might eventually provide a longer and more diagnostic magnetostratigraphy for correlation.

A magnetic polarity sequence was recently derived from Carnian and Norian "Hallstatt" limestones in southwestern Turkey. The sequence was based on the 73-m-thick Bolücektasi Tepe section [Gallet et al., 1992] and the 27-mthick Kavur Tepe section [Gallet et al., 1993]. Age control was established by conodont biostratigraphy which suggested major breaks in sedimentation; for example, the upper lower Norian and upper Norian are missing in the Bolücektasi Tepe section. The Kavur Tepe section served to fill the stratigraphic gaps in most of the Norian, although the proposed magnetobiostratigraphic correlation of the two now nearby sections required that they had originated at similar paleolatitudes but in opposite hemispheres (14 ${ }^{\circ}$ north for Bolücektasi Tepe, and $17^{\circ}$ south for Kavur Tepe). A major sedimentation break is also drawn between the Lower (Julian) and Upper (Tuvalian) Carnian; the preserved Upper Carnian limestones are highly condensed with hardly $3 \mathrm{~m}$ represented 


\title{
NEWARK BASIN
}

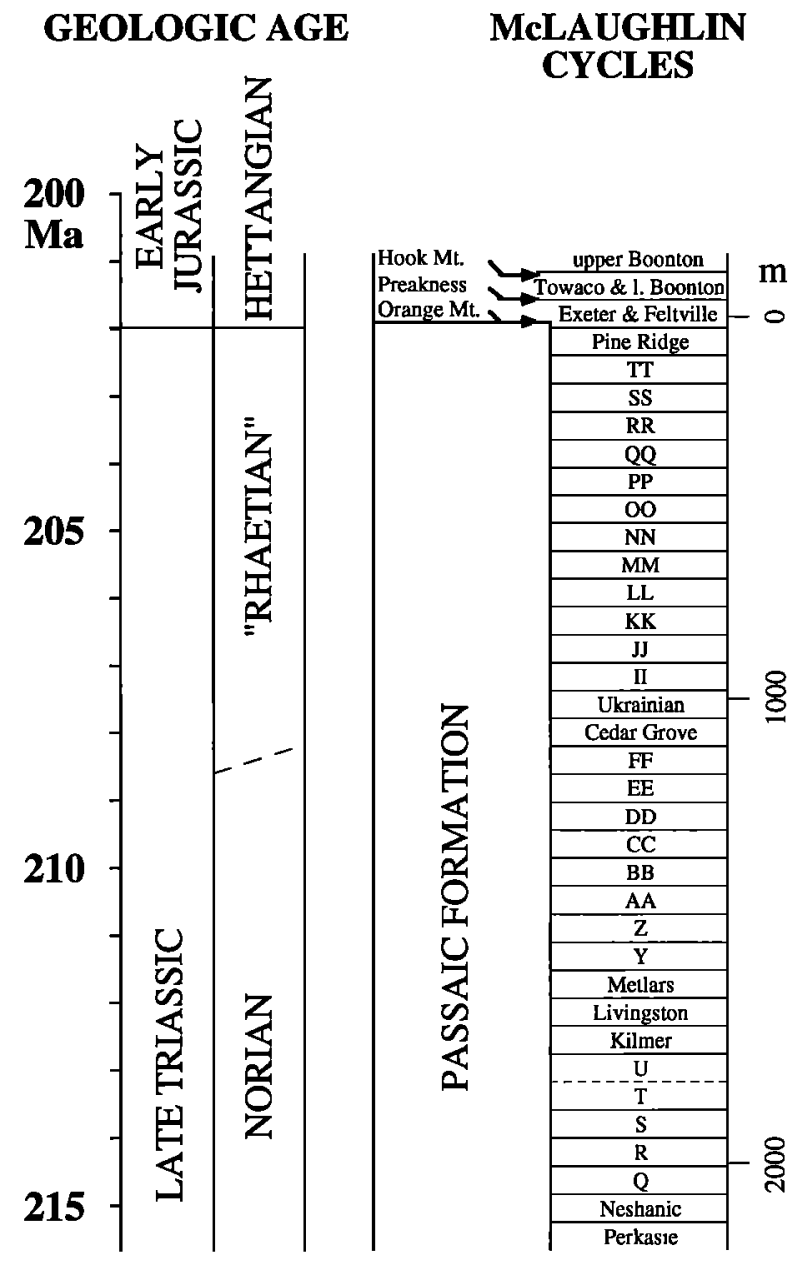

\author{
POLARITY \\ TIME SCALE
}

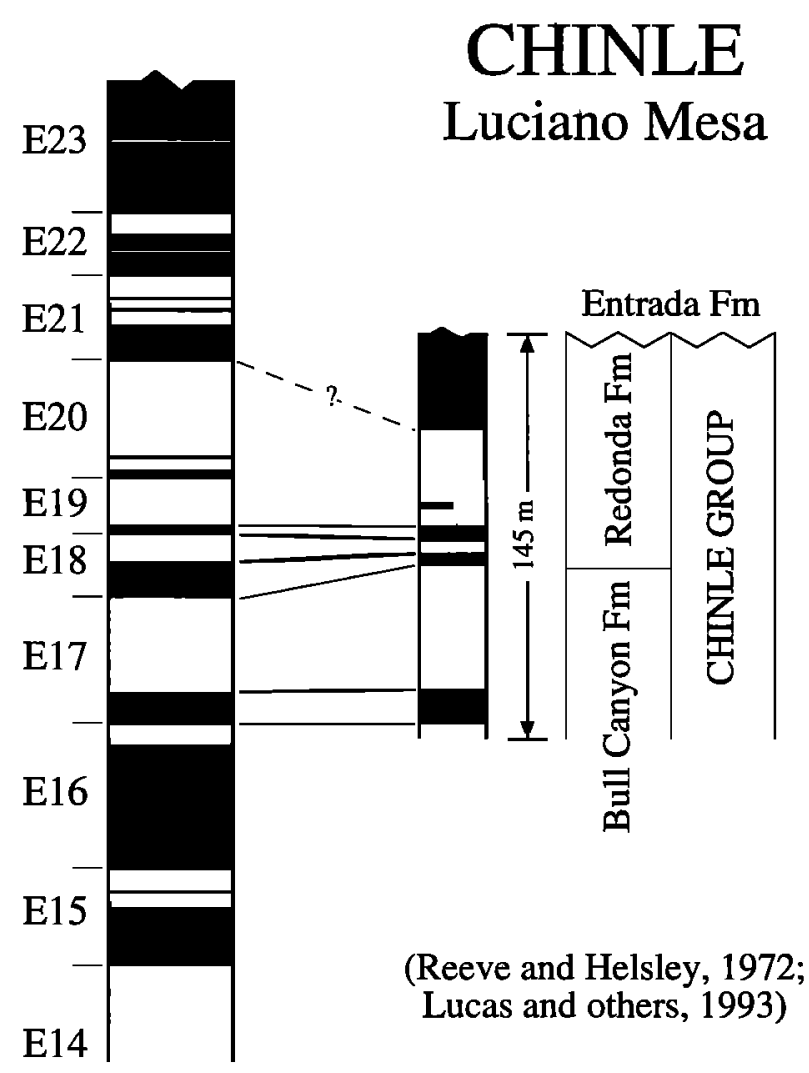

Figure 21. Possible correlation of the Luciano Mesa section of the nonmarine Chinle Group, New Mexico [Reeve and Helsley, 1972; Lucas et al., 1993] to the Newark geomagnetic polarity timescale. Entrada Formation is Middle Jurassic in age and unconformably overlies the Chinle.

in the Bolücektasi Tepe section and less than $2 \mathrm{~m}$ in another section at Erenkolu Mezarlik [Gallet et al., 1994]. Accordingly, we emphasize for correlation to the Newark the more continuous section at Kavur Tepe which according to Gallet et al. [1993] represents a record from (sub)substages Lacian 2 to Sevatian 2 of the Norian.

The thickest reversed (KT/B-) and normal (KT/E+) polarity magnetozones at Kavur Tepe suggest a correlation to the longest (and thickest) polarity intervals in the Norian part of the Newark sequence, namely magnetochrons E14r and E16n, respectively (Figure 22). Other first-order features of the polarity columns can then be reasonably linked, suggesting that the Kavur Tepe magnetostratigraphy corresponds to E14n to E19n of the Newark polarity sequence. Gallet et al. [1993] also transformed the Kavur Tepe magnetostratigraphy into a linear timescale, assuming an equal duration for ammonoid zones as inferred from the conodont biostratigraphy. KT/C3+ would then become the most prominent normal polarity interval, considerably longer than $\mathrm{KT} / \mathrm{E}+$, indicating that $\mathrm{KT} / \mathrm{C} 3+$ might instead correlate to Newark magnetochron E16n. This alternative correlation is less attractive, forcing mismatches like the very short $\mathrm{KT} / \mathrm{C} 1+$ being equivalent to the relatively long Newark magnetochron E15n. We believe that the assumption of equal duration for biozones distorts the polarity sequence at Kavur Tepe and might note that biozones are far from equal in duration in the Cenozoic where the timescale is well known [e.g., Berggren et al., 1985]. Stratigraphic thickness may in fact provide a better proxy for time in the Kavur Tepe section, the option we favor because it results in a more satisfactory correlation to the Newark polarity sequence. Our preferred correlation would also imply that the Alaunian is a shorter substage than the Sevatian, even though the former is thought to consist of three biozone subdivisions whereas the later has only two.

We have not been able to find a satisfactory correlation of the Bolücektasi Tepe section with the Newark. In the upper third of the Bolücektasi Tepe section and bounded by short reversed intervals and then sedimentary breaks, there is an approximately $25-\mathrm{m}$-thick normal polarity interval (not shown in Figure 22) spanning part of Alaunian 1, Alaunian 2, and part of Alaunian 3 which was correlated to the 2-m-thick $\mathrm{KT} / \mathrm{C} 3+$ magnetozone in Kavur Tepe on the basis of the 
NEWARK BASIN

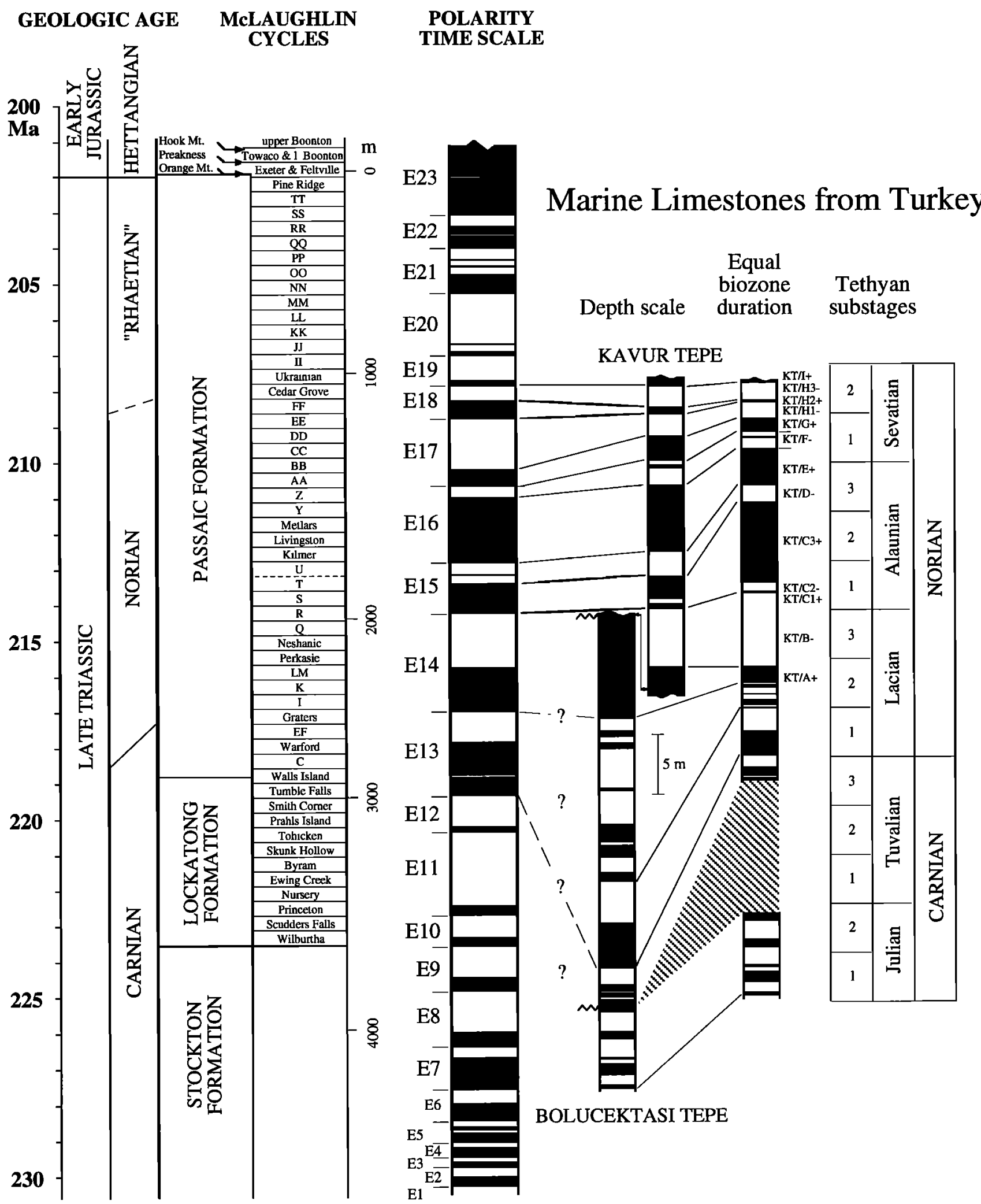

Figure 22. Magnetostratigraphies from marine limestone sections from Turkey (Bolücektasi Tepe [Gallet et al., 1992] and Kavur Tepe [Gallet et al., 1993]) with possible correlations to the Newark geomagnetic polarity timescale. Subdivisions of the Norian and Carnian are plotted on a linear timescale with arbitrary scale assuming equal duration of the Tethyan (sub)substages; magnetostratigraphies of the limestone sections are shown in terms of measured thickness (see scale) and as transformed in a composite to an equal biozone duration timescale on the basis of conodont biostratigraphy [Gallet et al., 1992, 1993]. The upper third of the Bolücektasi Tepe section, which includes an approximately 25 -m-thick normal polarity interval which was correlated to the KT/C3+ magnetozone in Kavur Tepe [Gallet et al., 1993], has been omitted for clarity. 
conodont biostratigraphy [Gallet et al., 1993]. Below a biostratigraphically defined sedimentary break nominally encompassing Lacian 3, the Bolücektasi Tepe section has about 15 polarity intervals over about $31 \mathrm{~m}$ of strata of Lacian 1 and Lacian 2 age (early Norian), with an additional eight polarity intervals over about $3 \mathrm{~m}$ of strata of Tuvalian 3 age (late Carnian) (Figure 22). At face value, this would suggest a reversal rate in excess of $5 / \mathrm{m}$.y. over a 3-4.5 m.y. interval in the late Carnian to early Norian. Such a high reversal frequency is not seen in the late Carnian to Norian interval of the Newark sequence. It is possible that many short polarity intervals are missing in the Newark record. However, the nominal resolution for magnetozones at the present level of sampling in the Newark is about twice the Van Houten cycle, or $\sim 40 \mathrm{kyr}$, and correspondingly short polarity intervals (defined by at least two samples) have indeed been delineated (e.g., E15r.1n (Figure 12); E21r.2n, E22n.1r, and E23n.1r (Figure 15)); there are also relatively few candidate magnetozones defined by only one sample (e.g., within E13r (Figure 11)). Considering also the repeatability in the between-site comparisons, we believe that the Newark polarity sequence is sufficiently complete to preclude missing polarity intervals as a viable explanation for the poor correlation of the Bolücektasi Tepe magnetostratigraphy. As Gallet et al. [1992, 1993] have cautioned, a number of the polarity intervals in the condensed limestone sections from Turkey are only tentatively defined by single samples; additional and preferably repeated magnetostratigraphic sections are clearly needed to confirm the polarity history for the late Carnian and early Norian in conjunction with an independent conodont biozonation.

In conclusion, while the correlations of available Late Triassic magnetostratigraphies should be regarded as tentative, we believe that the availability of the Newark reference sequence provides motivation and opportunity to develop an integrated and global timescale for the Late Triassic comparable to that developed for the later Mesozoic and Cenozoic.

Acknowledgments. We are grateful to the land owners and managers for giving us permission to drill on their property, particularly David H. Knights of the Princeton Forrestal Center of Princeton University and Alan Jones of Princeton Nurseries, David Stern of the Mercer County Department of Public Works, Frances Birdsall Zelinski and James Birdsall of Fieldview Farms, Elmer Smith of Bear Tavern Farm, Vernie R. Costan and William S. Richardson of Rutgers University, and Bruce Keeler and Robert Shay of the Somerset County Park Commission. We thank the Amoco Production Company and Kenneth Ciriacks, Donald Boyne, and Lynne Feldkamp for their commitment to the project, and to key personnel (Keith Milheim, David Bode, David Skidmore, Scott Randolf, Scott Gavin, Eric Cunningham, and Randy Sprague) for their superb work on the first six coring sites. DOSECC (Earl Hoskins and Roland Lawrence), Longyear Drilling Company (William Dycus and DuWayne Stoots), and Exlog (Thomas Paulson and Warren Wilkes) provided management, drilling, and core processing at the last site, and David Goldberg of Lamont and BPB Inc. skillfully logged the holes. Michael J. Miller, Robert Mancini, and Dick Dalton of the New Jersey Department of Environmental Protection were very helpful in guiding the permitting stage of the project, the General Counsels Office of Columbia University, particularly Susan Sgarlat, provided capable legal services, Loren Cox of Lamont was instrumental in initiating our involvement with Amoco, and Barry Raleigh encouraged us to submit the proposal for the Newark Basin Coring Project. We are appreciative of the meticulous paleomagnetic laboratory work of Gilberto Mello and gratefully acknowledge the support of this project by the Continental Dynamics Program of the National Science Foundation under grant EAR 89-16726. Constructive comments on the manuscript were received from the Journal reviewers (Yves Gallet, Maureen
Steiner, and Paul Van Veen) and the Associate Editor (James Ogg). LDEO contribution 5353.

\section{References}

Berger, A. L., Support for the astronomical theory of climatic change, Nature, 269, 44-45, 1977.

Berger, A., M. F. Loutre, and J. Laskar, Stability of the astronomical frequencies over the Earth's history for paleoclimate studies, Science, 255, 560-566, 1992.

Berggren, W. A., D. V. Kent, J. J. Flynn, and J. A. Van Couvering, Cenozoic geochronology, Geol. Soc. Am. Bull., 96, 1407-1418, 1985.

Cande, S. C., and D. V. Kent, A new geomagnetic polarity time scale for the Late Cretaceous and Cenozoic, J. Geophys. Res., 97, 13,917-13,951, 1992.

Cornet, B., The palynostratigraphy and age of the Newark Supergroup, $\mathrm{Ph} . \mathrm{D}$. thesis, 504 pp., Pa. State Univ., University Park, 1977.

Cornet, B., Applications and limitations of palynology in age, climatic, and paleoenvironmental analyses of Triassic sequences in North America, N. M. Mus. Nat. Hist. Sci. Bull., 3, 75-93, 1993.

Comet, B., and P. E. Olsen, A summary of the biostratigraphy of the Newark Supergroup of eastern North America with comments on Early Mesozoic provinciality, paper presented at III Congresso Latinoamericano de Paleontologia, Mexico, Simposio Sobre Floras del Triasico Tardio, su Fitogeografia y Paleoecologia, Memoria, pp. 67-81, Instituto de Geologia, Universidad Nacional Autonoma de Mexico, Mexico City, 1985.

DuBois, P. M., E. Irving, N. D. Opdyke, S. K. Runcorn, and M. R. Banks, The geomagnetic field in Upper Triassic times in the United States, Nature, 180, 1186-1187, 1957.

Dunning, G. R., and J. P. Hodych, U/Pb zircon and baddeleyite ages for the Palisades and Gettysburg sills of the northeastern United States: Implications for the age of the Triassic/Jurassic boundary, Geology, 18, 795-798, 1990.

Fedosh, M. S., and J. P. Smoot, A cored stratigraphic section through the northern Newark Basin, New Jersey, U.S. Geol. Surv. Bull., 1776, 19-24, 1988.

Fowell, S. J., and P. E. Olsen, Time calibration of Triassic/Jurassic microfloral turnover, eastern North America, Tectonophysics, 222, 361-369, 1993.

Fowell, S. J., B. Cornet, and P. E. Olsen, Geologically rapid Late Triassic extinctions: Palynological evidence from the Newark Supergroup, Spec. Pap. Geol. Soc. Am., 288, 197-206, 1994.

Froelich, A. J., and P. E. Olsen, Newark Supergroup, a revision of the Newark group in eastern North America, U.S. Geol. Surv. Bull., 1537, A55-A58, 1984.

Gallet, Y., J. Besse, L. Krystyn, J. Marcoux, and H. Theveniaut, Magnetostratigraphy of the Late Triassic Bolucektasi Tepe section (southwestern Turkey): Implications for changes in magnetic reversal frequency, Phys. Earth Planet. Inter., 73, 85-108, 1992.

Gallet, Y., J. Besse, L. Krystyn, H. Theveniaut, and Marcoux, Magnetostratigraphy of the Kavur Tepe section (southwestern Turkey): A magnetic polarity time scale for the Norian, Earth Planet. Sci. Lett., 117, 443-456, 1993.

Gallet, Y., J. Besse, L. Krystyn, H. Theveniaut, and J. Marcoux, Magnetostratigraphy of the Mayerling section (Austria) and Erenkolu Mezarlik (Turkey) section: Improvement of the Carnian (late Triassic) magnetic polarity time scale, Earth Planet. Sci. Lett., 125, 173-191, 1994.

Goldberg, D., D. Reynolds, C. Williams, W. K. Witte, P. E. Olsen, and D. V. Kent, Well logging results from the Newark Basin Coring Project (NBCP), Scientific Drilling, 4, 267-279, 1994.

Gradstein, F. M., F. P. Agterberg, J. G. Ogg, J. Hardenbol, P. Van Veen, J. Thierry, and Z. Huang, A Mesozoic Time Scale, J. Geophys. Res., 99, 24,051-24,074, 1994.

Haq, B. U., J. Hardenbol, and P. R. Vail, Mesozoic and Cenozoic chronostratigraphy and cycles of sea-level change, Spec. Pub. Soc. Econ. Paleontol. Mineral., 42, 71-108, 1988.

Harland, W. B., A. V. Cox, P. G. Llewellyn, C. A. G. Pickton, A. G. Smith, and R. Walters, A Geologic Time Scale, 131 pp., Cambridge Univ. Press, New York, 1982.

Harland, W. B., R. L. Armstrong, A. V. Cox, L. E. Craig, A. G. Smith, and D. G. Smith, A Geologic Time Scale 1989, 263 pp., Cambridge Univ. Press, New York, 1990.

Hilgen, F. J., Extension of the astronomically calibrated (polarity) time 
scale to the Miocene/Pliocene boundary, Earth Planet. Sci. Lett., 107, 349-368, 1991.

Hodych, J. P., and G. R. Dunning, Did the Manicouagan impact trigger end-of-Triassic mass extinction?, Geology, 20, 51-54, 1992.

Huber, P., S. G. Lucas and A. P. Hunt, Vertebrate biochronology of the Newark Supergroup Triassic, eastern North America, N. M. Mus. Nat. Hist. Sci. Bull., 3, 179-186, 1993.

Irving, E., and G. Pullaiah, Reversals of the geomagnetic field, magnetostratigraphy, and relative magnitude of paleosecular variation in the Phanerozoic, Earth Sci. Rev., 12, 35-64, 1976.

Kent, D. V., and W. K. Witte, Slow apparent polar wander for North America in the Late Triassic and large Colorado Plateau Rotation, Tectonics, 12, 291-300, 1993.

Khramov, A. N., Paleomagnetology, 308 p., Springer-Verlag, New York, 1987

Kirschvink, J. L., The least-squares line and plane and the analysis of palaeomagnetic data, Geophys. J. R. Astron. Soc., 62, 699-718, 1980.

Kodama, K. P., Magnetic and gravity evidence for a subsurface connection between the Palisades sill and the Ladentown basalts, Geol. Soc. Am. Bull., 94, 151-158, 1983.

Kodama, K. P., C. Hedlund, J. Gosse, and J. Strasser, Rotated paleomagnetic poles from the Sassamansville syncline, Newark Basin, southeastern Pennsylvania, J. Geophys. Res., 99, 4643$4653,1994$.

Larson, E. E., and T. R. Walker, Development of chemical remanent magnetization during early stages of red-bed formation in Late Cenozoic sediments, Baja California, Geol. Soc. Am. Bull., 86, 639-650, 1975

Litwin, R. J., A. Traverse, and S. R. Ash, Preliminary palynological zonation of the Chinle Formation, southwestern U.S.A., and its correlation to the Newark Supergroup (eastern U.S.A.), Rev. Palaeobot. Palynology, 68, 269-287, 1991.

Lowrie, W., and L. Lanci, Magnetostratigraphy of Eocene-Oligocene boundary sections in Italy: No evidence for short subchrons within chrons 12R and 13R, Earth Planet. Sci. Lett., 126, 247-258, 1994.

Lowrie, W., J. E. T. Channell, and F. Heller, On the credibility of remanent magnetization measurements, Geophys. J. R. Astron. Soc., 60, 493-496, 1980.

Lucas, S. G., and P. Huber, Revised internal correlation of the Newark Supergroup Triassic, eastern United States and Canada, N. M. Mus. Nat. Hist. Sci. Bull., 3, 311-319, 1993.

Lucas, S. G., and A. P. Hunt, Tetrapod biochronology of the Chinle Group (Upper Triassic), western United States, N. M. Mus. Nat. Hist. Sci. Bull., 3, 327-329, 1993.

Lucas, S. G., M. B. Steiner, P. Huber, and A. P. Hunt, Magnetostratigraphy and paleomagnetic poles from Late Triassicearliest Jurassic strata of the Newark Basin: Discussion, Geol. Soc. Am. Bull., 105, 1260-1261, 1993.

Manspeizer, W., Late Triassic-Early Jurassic rifting and opening of the Atlantic: An overview, in Triassic-Jurassic Rifting, Continental Breakup, and the Formation of the Atlantic Ocean and Passive Margins, edited by W. Manspeizer, pp. 41-79, Elsevier, New York, 1988.

McElhinny, M. W., and P. J. Burek, Mesozoic paleomagnetic stratigraphy, Nature, 232, 98-102, 1971.

McFadden, P. L., and A. B. Reid, Analysis of palaeomagnetic inclination data, Geophys. J. R. Astron. Soc., 69, 307-319, 1982.

McIntosh, W. C., R. B. Hargraves, and C. L. West, Paleomagnetism and oxide mineralogy of upper Triassic to lower Jurassic red beds and basalts in the Newark Basin, Geol. Soc. Am. Bull., 96, 463-480. 1985

McLaughlin, D. B., Type sections of the Stockton and Lockatong Formations, Proc. Acad. Sci., Pa., 19, 102-113, 1945.

McLaughlin, D. B., Mesozoic rocks, Bull. C-9, pp. 55-114, Pa. Geol. Surv., 1959.

Molina-Garza, R. S., J. W. Geissman, R. Van der Voo, S. G. Lucas, and S. N. Hayden, Paleomagnetism of the Moenkopi and Chinle Formations in central New Mexico: Implications for the North American apparent polar wander path and Triassic magnetostratigraphy, J. Geophys. Res., 96, 14,239-14,261, 1991.

Odin, G. S., and R. Létolle, The Triassic time scale in 1981, in Numerical Dating in Stratigraphy, edited by G. S. Odin, pp. 523533, Wiley-Interscience, New York, 1982.

Olsen, P. E., On the use of the term Newark for the Triassic and Early Jurassic rocks of eastern North America, News. Stratig., 7, 90-95, 1978.
Olsen, P. E., The latest Triassic and Early Jurassic formations of the Newark Basin (Eastern North America, Newark Supergroup): Stratigraphy, structure, and correlation, N. J. Acad. Sci. Bull., 25, 25-51, 1980

Olsen, P. E., A 40-million-year lake record of early Mesozoic orbital climatic forcing, Science, 234, 842-848, 1986.

Olsen, P. E., and M. S. Fedosh, Duration of the early Mesozoic igneous episode in eastern North America determined by use of Milankovitch-type lake cycles, Geol. Soc. America, Abstr. Programs, 20, 59, 1988.

Olsen, P. E., and P. M. Galton, Triassic-Jurassic extinctions: Are they real?, Science, 197, 983-986, 1977.

Olsen, P. E, and P. M. Galton, A review of the reptile and amphibian assemblages from the Stormberg of southern Africa, with special emphasis on the footprints and age of the Stormberg, Palaeontol. Afri., 25, 87-110, 1984.

Olsen, P. E., and D. V. Kent, Milankovitch climate forcing in the tropics of Pangea during the Late Triassic, Paleogeogr. Paleoclimatol. Paleoecol, in press, 1995

Olsen, P. E., and H.-D. Sues, Correlation of continental Late Triassic and Early Jurassic sediments, and patterns of the Triassic-Jurassic tetrapod transition, in The Beginning of the Age of Dinosaurs: Faunal Change Across the Triassic Jurassic Boundary, edited by $\mathrm{K}$. Padian, pp. 321-351, Cambridge Univ. Press, New York, 1986.

Olsen, P. E., S. J. Fowell, and B. Cornet, The Triassic/Jurassic boundary in continental rocks of eastern North America: A progress report, Spec. Pap. 247, Geol. Soc. Am., 585-593, 1990.

Olsen, P. E., A. R. McCune, and K. S. Thomson, Correlation of the Early Mesozoic Newark Supergroup by vertebrates, principally fishes, Am. J. Sci., 282, 1-44, 1982.

Olsen, P. E., N. H. Shubin, and M. H. Anders, New Early Jurassic tetrapod assemblages constrain Triassic-Jurassic tetrapod extinction event, Science, 237, 1025-1029, 1987.

Olsen, P. E., D. V. Kent, B. Cornet, W. K. Witte, and R.W. Schlische, High resolution stratigraphy of the more than $5000 \mathrm{~m}$ Newark rift basin section (early Mesozoic, eastern North America), Geol. Soc. Am. Bull., in press, 1995.

Opdyke, N. D., The paleomagnetism of the New Jersey Triassic: A field study of the inclination error in red sediments, J. Geophys. Res., 66, 1941-1949, 1961.

Palmer, A. R., The Decade of North American Geology 1983 geologic timescale, Geology, 11, 503-504, 1983.

Pechersky, D. M., and A. N. Khramov, Mesozoic palaeomagnetism scale of the USSR, Nature, 244, 499-501, 1973.

Prevot, M., and M. McWilliams, Paleomagnetic correlation of the Newark Supergroup volcanics, Geology, 17, 1007-1010, 1989.

Ratcliffe, N. M., Reinterpretation of the relationship of the western extension of the Palisades sill to the lava flows at Ladentown, New York, based on new core data, U.S. Geol. Surv. Bull., 1776, 113135, 1988.

Reeve, S. C., and C. E. Helsley, Magnetic reversal sequence in the upper portion of the Chinle Formation, Montoya, New Mexico, Geol. Soc. Am. Bull., 83, 3795-3812, 1972.

Reeve, S. C., D. Leythaeuser, C. E. Helsley, and K. W. Bay, Paleomagnetic results from the Upper Triassic of East Greenland, J. Geophys. Res., 79, 3302-3307, 1974.

Reynolds, R. L., M. L. Tuttle, C. A. Rice, N. S. Fishman, J. A. Karachrewski. and D. M. Sherman, Magnetization and geochemistry of greigite-bearing Cretaceous strata, North Slope Basin, Alaska, Am. J. Sci., 294, 485-528, 1994.

Roden, M. K., and D. S. Miller, Tectonothermal history of Hartford, Deerfield, Newark and Taylorsville Basins, eastern United States, using fission-track analysis, Schweiz. Mineral. Petrogr. Mitt., 71, 187-203, 1991.

Schlische, R. W., Structural and stratigraphic development of the Newark extensional basin: Evidence for the growth of the basin and its bounding structures, Geol. Soc. Am. Bull., 104, 1246-1263, 1992.

Schneider, D. A., Time-averaged paleomagnetic field of the PlioPleistocene from deep-sea sediments, Ph. D. thesis, 243 pp., Columbia Univ., New York, 1989.

Shackleton, N. J., A. Berger, and W. R. Peltier, An alternative astronomical calibration of the lower Pleistocene timescale based on ODP Site 677, Trans. R. Soc. Edinburgh Earth Sci., 81, 251-261, 1990.

Silvestri, S. M., and M. J. Szajna, Biostratigraphy of vertebrate footprints in the Late Triassic section of the Newark Basin, 
Pennsylvania: Reassessment of stratigraphic ranges, $N . M$. Mus. Nat. Hist. Sci. Bull., 3, 439-445, 1993.

Smith, T. E., and H. C. Noltimier, Paleomagnetism of the Newark Trend igneous rocks of the north central Appalachians and the opening of the central Atlantic Ocean, Am. J. Sci., 279, 778-807, 1979.

Smoot, J. P., Sedimentary facies and depositional environments of early Mesozoic Newark Supergroup basins, eastern North America, Paleogeogr. Paleoclimatol. Paleoecol., 84, 369-423, 1991.

Smoot, J. P., and P. E. Olsen, Climate cycles as sedimentary controls of rift basin lacustrine deposits in the early Mesozoic Newrak Basin based on continuous core, in Lacustrine Depositional Systems, SEPM Core Workshop Notes, vol. 19, edited by T. Lomando and M. Harris, pp. 201-237, Society of Economic Paleontologists and Mineralogists, Tulsa, Okla., 1994.

Steckler, M. S., G. I. Omar, G. D. Karner, and B. P. Kohn, Pattern of hydrothermal circulation within the Newark Basin from fission-track analysis, Geology, 21, 735-738, 1993.

Sutter, J. F., Innovative approaches to the dating of igneous events in the early Mesozoic basins of the eastern United States, U.S. Geol. Surv. Bull., 1776, 194-200, 1988.

Symons, D. T. A., R. E. Bormann, and R. P. Jans, Paleomagnetism of the Triassic red beds of the lower Fundy Group and Mesozoic tectonism of the Nova Scotia platform, Canada, Tectonophysics, 164, 13-24, 1989.

Szajna, M. J., and B. Hartline, New vertebrate footprint assemblages from the Rhaetian interval of the Passaic Formation in Berks County, Pennsylvania, Geol. Soc. Am. Abstr. Programs, 27, 86, 1995.

Tozer, E. T., Triassic chronostratigraphic divisions considered again, Albertiana, 11, 32-37, 1993.

Van Fossen, M. C., J. J. Flynn, and R. D. Forsythe, Paleomagnetism of Early Jurassic rocks, Watchung Mountains, Newark Basin: Evidence for complex rotations along the border fault, Geophys. Res. Lett., 13, 185-188, 1986.

Van Houten, F. B., Cyclic lacustrine sedimentation, Upper Triassic
Lockatong Formation, central New Jersey and adjacent Pennsylvania, Kans. Geol. Surv. Bull., 169, 497-531, 1964.

Van Veen, P. M., Time calibration of Triassic/Jurassic microfloral turnover, eastern North America: Comment, Tectonophysics, in press, 1995.

Webb, J. A., A radiometric time scale of the Triassic, J. Geol. Soc. Austr., 28, 107-121, 1981.

Wheeler, G., Triassic fault-line deflections and associated warping, $J$. Geol., 47, 337-370, 1939.

Witte, W. K., and D. V. Kent, A middle Carnian to early Norian ( 225 Ma) paleopole from sediments of the Newark Basin, Pennsylvania, Geol. Soc. Am. Bull., 101, 1118-1126, 1989.

Witte, W. K., and D. V. Kent, The paleomagnetism of red beds and basalts of the Hettangian Extrusive Zone, Newark Basin, New Jersey, J. Geophys. Res., 95, 17,533-17,545, 1990.

Witte, W. K. and D. V. Kent, Tectonic implications of a remagnetization event in the Newark Basin, J. Geophys. Res., 96, $19,569-19,582,1991$.

Witte, W. K., D. V. Kent, and P. E. Olsen, Magnetostratigraphy and paleomagnetic poles from Late Triassic-earliest Jurassic strata of the Newark Basin, Geol. Soc. Am. Bull., 103, 1648-1662, 1991.

Witte, W. K., D. V. Kent, and P. E. Olsen, Reply to discussion by Lucas, S.G., M.B. Steiner, P. Huber, and A.S. Hunt "Magnetostratigraphy and paleomagnetic poles from the Late Triassic-earliest Jurassic strata of the Newark Basin", Geol. Soc. Am. Bull., 105, 1260-1262, 1993.

D.V. Kent and P.E. Olsen, Lamont-Doherty Earth Observatory, Palisades, NY 10964. (e-mail: dvk@Idgo.columbia.edu)

W.K. Witte, Geophysical Institute, University of Alaska, Fairbanks, AK 99775. (e-mail: wwitte@polarnet.fnsb.ak.us)

(Received November 17, 1994; revised March 22, 1995;

accepted March 28, 1995.) 